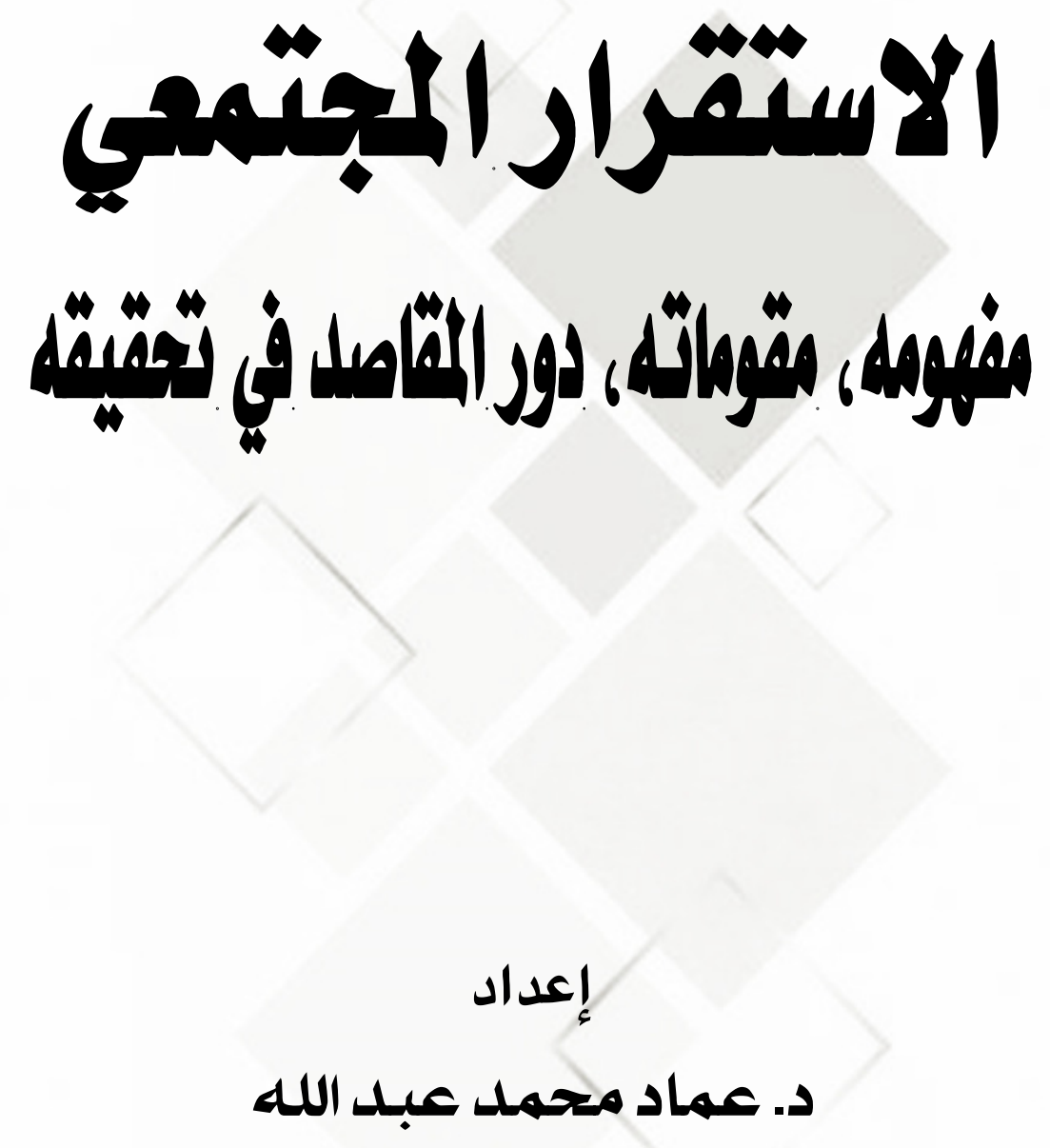

دكتوراة في أصول الدين في الدعوة والثقافة الإسلامية جامعة الأزهر. 



\section{الاستقرار المجتمعي، مفهومه - مقوماته - دور المقاصد في تحقيقه}

عماد محمد عبد الله

الدعوة والثقافة الإسلامية، كلية أصول الدين، جامعة الأزهر، القاهرة،

$$
\text { ملخهورية مصر العربية. }
$$

تضطلع هذه الدراسة بالوقوف على مفهوم الاستقرار المجتمعي من خلال المنظور المقان

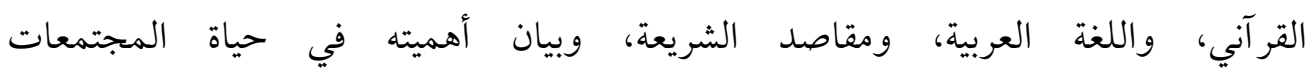

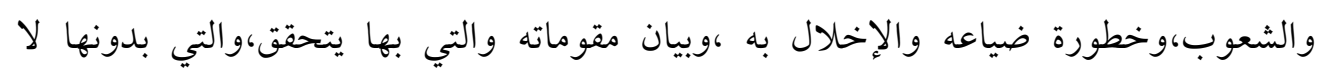

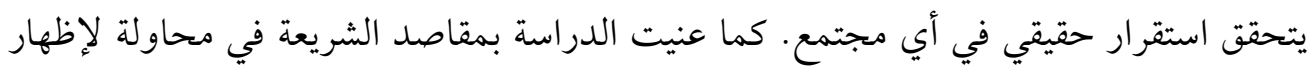

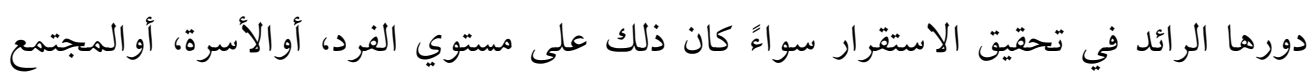

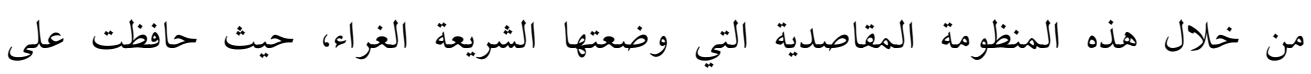

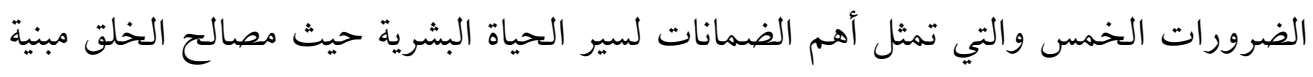

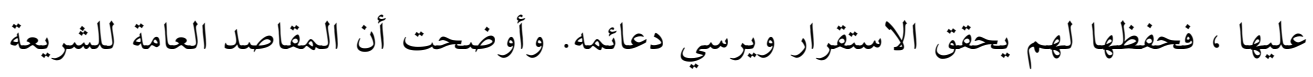

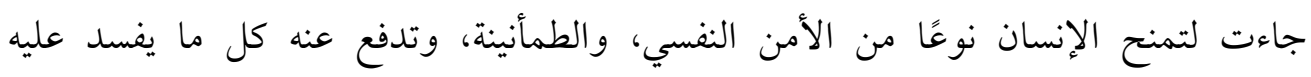

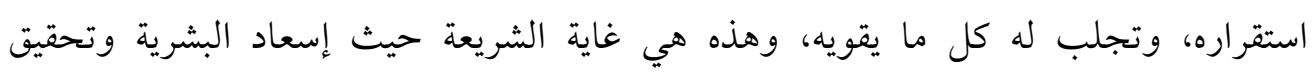
الاستقرار وإشاعة المحبة والسلام بين الجميع.

الكلمات المفتاحية: الاستقرار المجتمعي، مقاصد الشريعة، المقاصد الضرورية، المقاصد العامة. 


\section{Social stability, its concept - its components - the role of purposes in achieving it}

Emad Muhammad Abdullah

Islamic Dawah and Culture, Faculty of Theology, Al-Azhar University, Cairo, Arab Republic of Egypt.

Email: emamna68@yahoo.com

\section{Abstract :}

This study undertakes to stand on the concept of community stability through the Qur'anic perspective, the Arabic language, and the purposes of Shariah, and to indicate its importance in the lives of societies and peoples, and the danger of its loss and breach, and the statement of its components and by which it is achieved, without which no real stability is achieved in any society. The study was also concerned with the purposes of Shariah in an attempt to show its leading role in achieving stability, whether at the level of the individual, the family, or society through this intentional system established by the noble Shariah, as it preserved the five necessities, which represent the most important guarantees for the course of human life where the interests of creation are based on them. Keeping it for them achieves stability and lays its foundations. It explained that the general purposes of Shariah came to give man a kind of psychological security and tranquility, and pay for everything that spoils his stability, and bring him everything that strengthens him.

Keywords: Social stability, The objectives of the Shariah, The necessary objectives, The general objectives. 


\section{المقتحنّ}

الحمد لله العلي القدير، الذي شملت قدرته كل مخلوق، وقدر مقادير

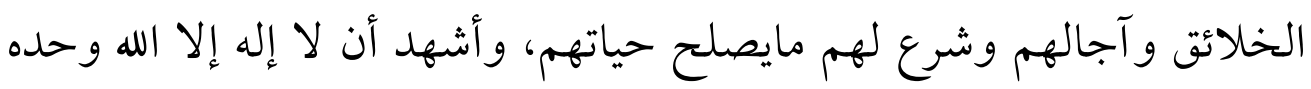

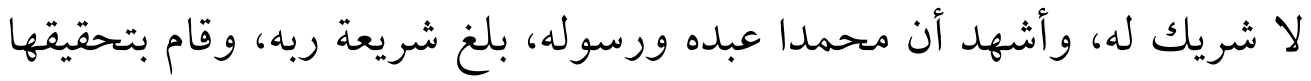

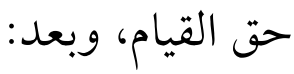

فإن الله تعالى قد جعل الأمن والاستقرار من أعظم ما أنعم به على

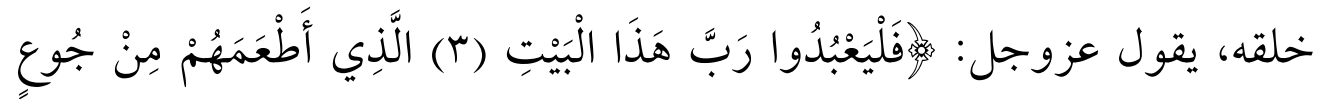

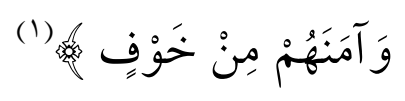

بل جعل سبحانه الاستقرار من النعيم المقيم لأهل جنته ودار كرامته،

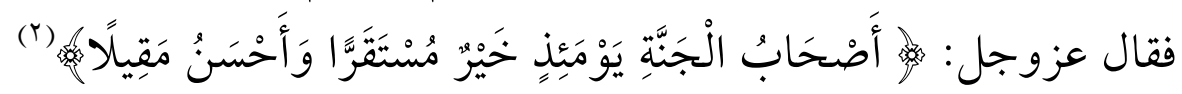

وبتحقيق الاستقرار في حياة الإنسان يكون قد حاز خير الدنيا، حيث

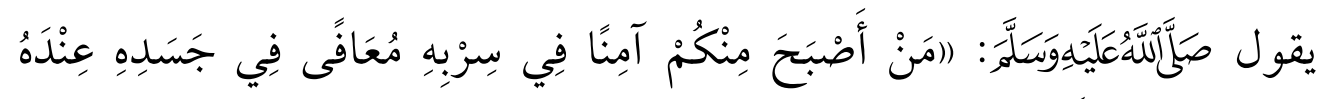

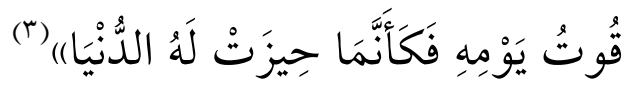

$$
\begin{aligned}
& \text { (1) [سورة قريش الآية: ب، ؟] }
\end{aligned}
$$

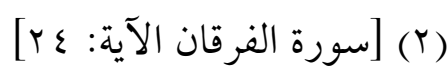

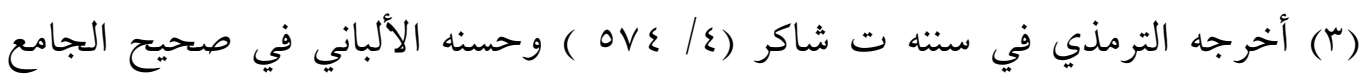

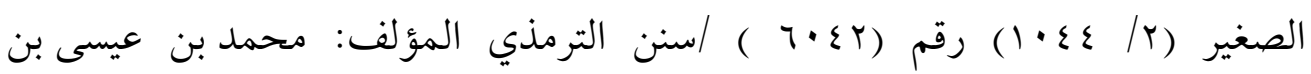

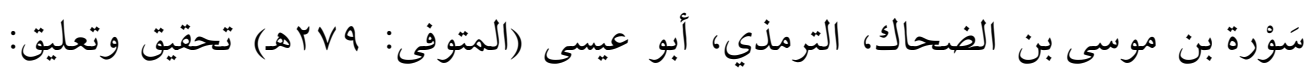

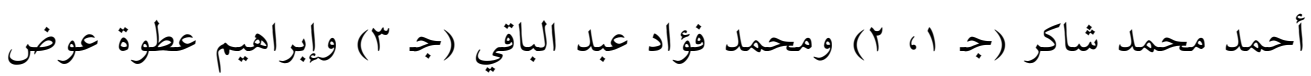

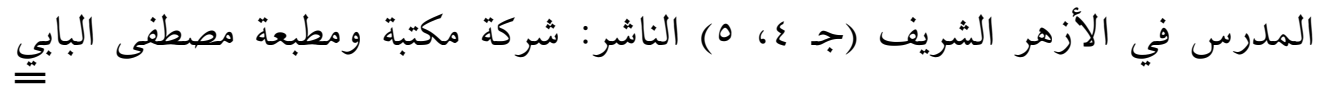


ولذلك يعد فقدان الاستقرار والأمن من البلاء العظيم كما قال سبحانه:

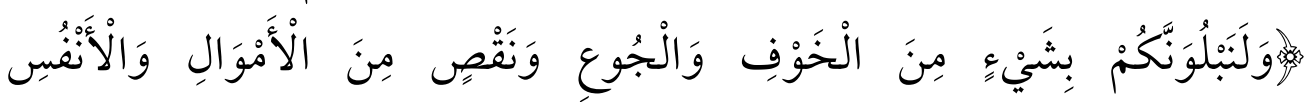

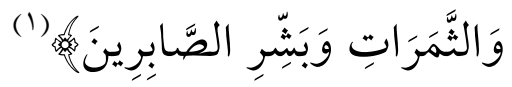

ولهذا يعتبر الاستقرار من ضروريات الحياة للمجتمات البشرية، فهي تحرص عليه وتبذل الغالي والرخيص في سبيل تحقيقة، وتسعي في البعد عن كل أسباب الشقاء والقلق.

والاستقرار المجتمعي له أهميته الكبيرة في حياة الإنسان حيث يقوى فيه الإيجابية، والقدرة على التفكير الهادئ، والارتقاء بالمجتمع، والرقي به، والعمل على تحقيق مستقبل مشرق بناء.

أما شعوره بالقلق وعدم الاستقرار فلاشك يدفعه إلي اليأس والقنوط، وبالتالي فإنه لا يبذل أي محاولة لتغيير الواقع من حوله فيصل إلي الجمود والتخلف و والرجعية.

ولا يتحقق الاستقرار المجتمعي إلا من خلال مقومات لابد من تحقيقها في حياة المجتمعات حتي تنعم به ومن أهمها: الإيمان بالهه و التوكل عليه، فالقلب لايشعر بطمأنينة واستقرار إلا في رحاب الله، وكذلك الترابط المجتمعيى، والتعايش السلمي بين أفراد المجتمع، وتحقيق الوسطية

الحلبي - مصرالطبعة: الثانية، 90 90 أهـ - 9V0 ام، /صحيح الجامع الصغير وزياداته

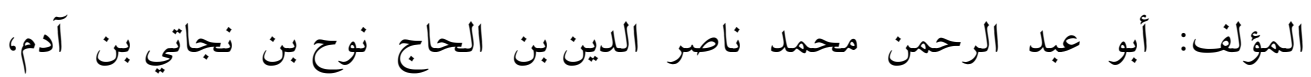

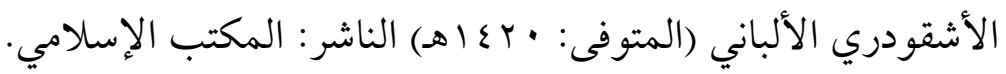

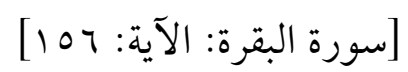




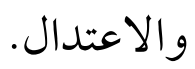

ومقاصد الشريعة لها الدور البارز في تحقيق الاستقرار بمقوماته، حيث وضعت من التدابير الوقائية والعلاجية لنشره وترسيخه وحر استه، لإنها جاءت لإقامة مجتمع فاضل يسعد فيه الجميع. و هذه المقومات هي التي قام عليها مجتمع المدينة الأول الذي أقامه

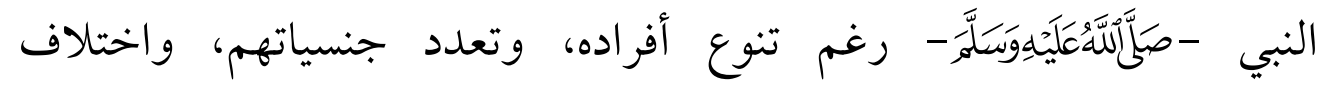
شرائعهم، وطبائعهم، فكان هذا المجتمع نموذجاً للاستقرار الحقيقي والذي توني انتشر نوره بعد ذلك في إنحاء المعمورة.

وبناءُ عليه فإن للاستقرار المجتمعي أهمية كبرى في حياةالأمم والشعوب، وللوقوف علي حقيقة الاستقرار المجتمعي وقواعده وأصوله كانت هذا الدراسة المباركة، والتي اختارها المؤتمر العلمي الأول لكلية الشريعة والقانون بالقاهرة -حفظها الله- والتي بعنوان: "دور الشريعة والقانون في استقرار المجتمعات"، وقداخترت المحور الأول للكتابة فيه وعنونته: "بالاستقرار المجتمعي مفهومه مقوماته دور المقاصد في تحقيقه "، لعلها تكون خطوة علي طريق الإصلاح، واخيراً أتقدم بخالص الشكر والتقدير و العرفان لجامعتنا العريقة، وللسادة القائمين على هذا المؤتمر.

\section{أولاً : أهمية الموضوع.}

- - حاجة المجتمع إلي إدراك مفهوم الاستقرار ومقوماته، لأنه أصابه شيئ من الإنحر اف في الواقع المعاصر.

r- إبراز دور مقاصد الشريعة وتدابيرها الوقائية والعلاجية في نشر 
وترسيخ وحراسة الاستقرار المجتمعي.

r - معالجة هذا الموضوع يدل على كمال الشريعة وشمولها لحياة الناس، ورعايتها لمصالحهم، ومسايرتها لمستجداتهم.

\section{ثانياً : اللدربسات السابقة.}

قد لاحظت ندرة أو غياب أي كتابات شرعية كلية وشاملة في كل ما وقعت عليه عيني في موضوع: "الاستقرار المجتمعي مفهومه مقوماته دور المقاصد في تحقيقه "، ومما كتب في موضوع الاستقرار والأمن على سبيل المثال لا الحصر:

\section{أ- متطلبات المحافظة على نعمة الأمن والاستقرار(1)}

ب-أصالة المنهج في سيرة الملك عبد العزيز وأثر ذلك في الاستقرار

(r) (الشامل

$$
\text { ج-أثرتطبيق الشريعة في حل المشكلاة الناس وأهميته في الإسلام. }
$$

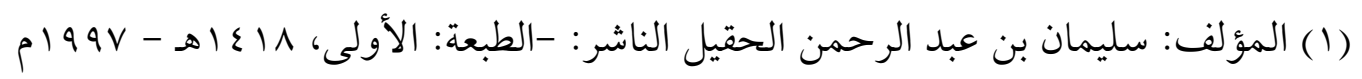

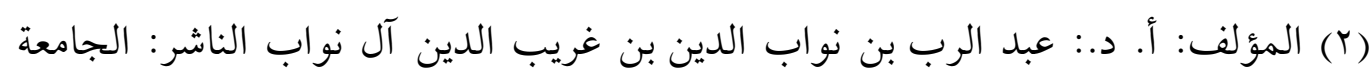

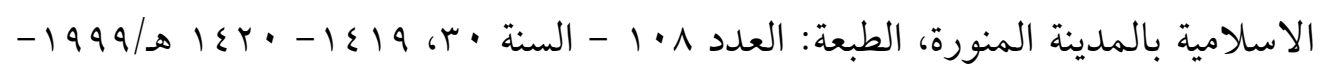

(r) المؤلف: عبد الله بن عبد المحسن بن عبد الرحمن التركي الناشر: الكتاب منشور على موقع وزارة الأوقاف السعودية بدون بيانات.

(ع) المؤلف: أ. د. إبراهيم بن مبارك الجوير الناشر: مكتبة العيكبان، الرياض السعودية $=$ 
أما بحثي فهى محاولة لإبراز: دور الشريعة في تحقيق الاستقرار، وذلك بييان مفهومه والوقوف على حقيقته، وبيان أهميته، وخطورة الإخلال بها،

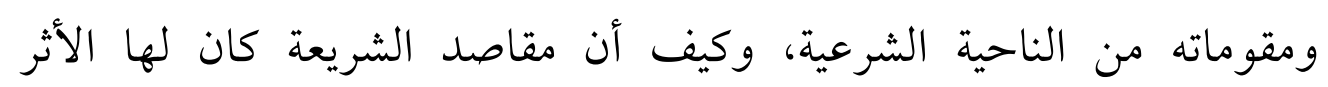
الواضح في نشره وترسيخه على مستوي الفرد والأسرة والمجتمع بل والإنسانية جمعاء.

\section{ثالثاً : منهج البحث.}

أمّا عن منهجي في البحث، فلقد استخدمت في هذا البحث عدداً من مناهج البحث العلمى وهي: (المنهج الوصفي) و(المنهج الاستدلالي) و(المنهج الاستنباطى). رابعاً : خطة البحث.

هذا وقد جعلت خطة البحث مرتبة على: مقدمة وثلاثة مباحث وخاتمة.

فأمّا المقدمة فتشتمل على : أهمية البحث.

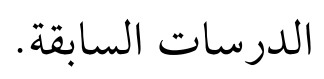
خطة البحث. وَهُوَ مُرَتِب على :ثلاثة مباحث. الطبعة الأولي ع 99 ام. 
المبحث الأول: الاستقرار المجتمعي مفهومه وأهميته. وَهُوَ مُرَتِب على مطلبين: المطلب الأول: مفهوم الاستقرار المجتمعي. المطلب الثاني: أهمية الاستقرار وخطورة الإخلال به. المبحث الثاني: مقومات الاستقرار المجتمعي. وَهُوَ مُرَتبّب على خمسة مطالب:

$$
\begin{aligned}
& \text { المطلب الأول: تحقيق الإيمان. } \\
& \text { المطلب الثاني: تحقيق الأخوة والترابط. } \\
& \text { المطلب الثالث: تحقيق العدل. } \\
& \text { المطلب الرابع: تحقيق التعايش السلمي. } \\
& \text { المطلب الخامس: تحقيق الوسطية والاعتدال. }
\end{aligned}
$$

المبحث الثالث: الاستقرار المجتمعي في ضوء مقاصد الشريعة. وَهُوَ

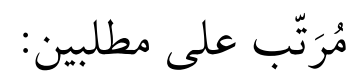
المطلب الأول: المقاصد الضرورية وتحقيق الاستقرار المجتمعي. المطلب الثاني: المقاصد العامة وتحقيق الاستقرار المجتمعي. أمَّا الخاتمة فتشتمل على: خلاصة البحث، ونتائجه، ثم الفهرس العام للبحث. هذا، وقد بذلت جهدا في معالجة قضايا هذا البحث ما استطعت إلى 
ذلك سبيلاً، مستعينا باله تعالى، فإذا وفقت إلى الصواب فمن فضل الله سبحانه وتوفيقه -، وإن كان غير ذلك، فمن نفسي والشيطان، وأرجو النصح و التسديد.

وأخيرًا أسأل الله - تعالى - أن يجعل هذا العمل خالصًا لوجهه الكريم،

وأن يوفقنا إلى ما يحبه ويرضاه إنه أكرم مسئول وأعظم مأمول، وصلى الله على سيدنا محمد وعلى آله وصحبه وسلم. الباحث

(2)

العدد السادس والثلاثون .r.r. 


\section{المبحث الأول}

الاستقرار المججمعي مفهومه وأهميته.

$$
\text { المطلب الأول: مفهوم الاستقرار المجتمعي. }
$$




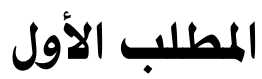

\section{مفهوم الاستقرارالمجتمعي}

تحديد المفاهيم وتعريفها مدخل هام لكل علم من العلوم وذلك؛لأن

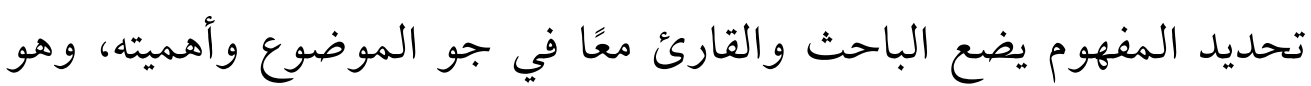
الوعاء الذي تطرح من خلاله الأفكار.

فإذا ما اضطرب ضبط هذا الوعاء أو اختلت دلالاته التعبيرية اختل البناء

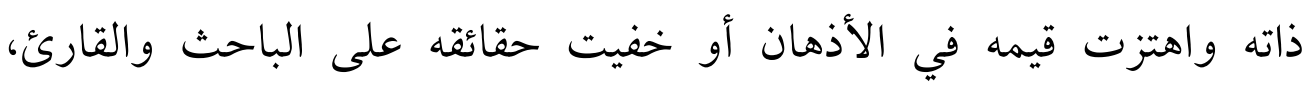

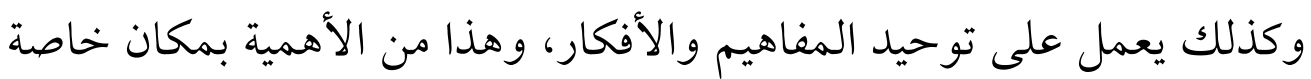

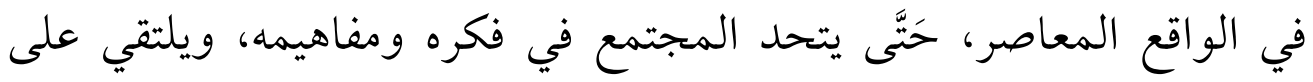

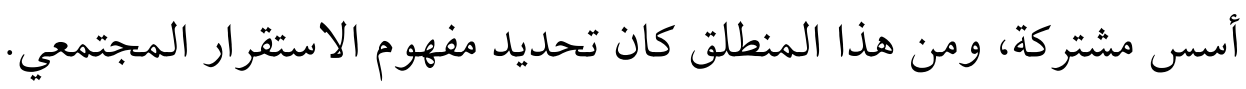
ومن المعلوم أن المفهوم أعم واشمل من المصطلح؛ لأن المصطلح خاص بفن من الفنون، أما المفهوم فهو متصل بقضايا الدين والهوية،

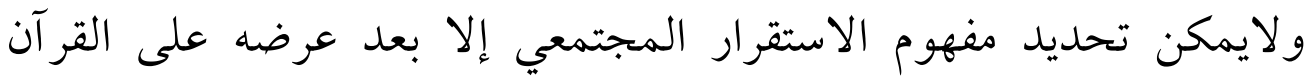

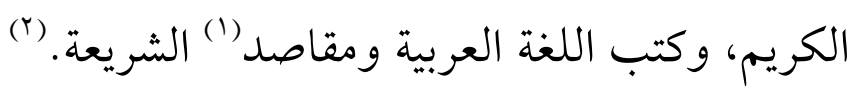

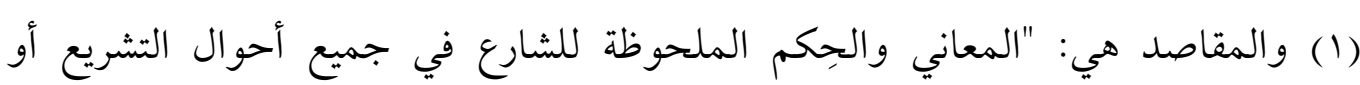

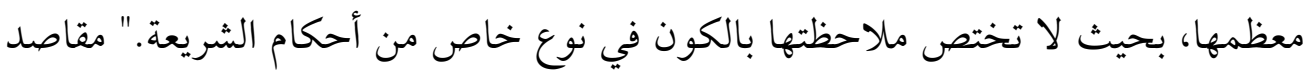

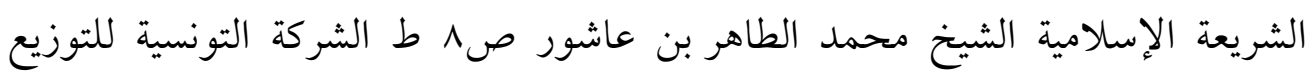
ط

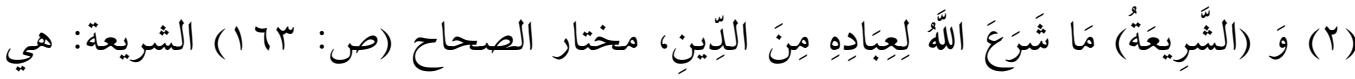

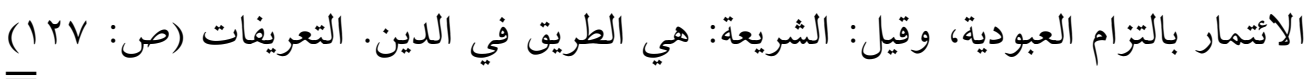




\section{أولاً : تعريف الاستقرارالمجتمعي (1) كما جاء في كتب اللغة:}

الاستقرار مصدر إستقر، ويطلق في اللغة على معالٍ متعددة: فيطلق تارة ويراد منه:الثبات والسكن، فقي المعجم الوسيط يقال:"فُلَان

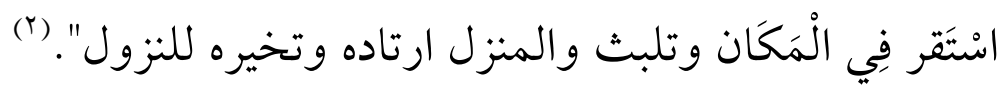

وفي القاموس الفقهي: يقال:استقر بالمكان:أي ثبت، وسكن، وأقر فلانا

بالمكان: ثبته وسكنه. (r)

ويطلق تارة ثانية: وير اد منه التمكن يقال:(انْتَقر ) بِالْمَكَانِ تمكن وَسكن.

ويطلق ثالثة:ويراد منه الثبوت والغاية، والنهاية والقرار، (فالمستقر)يعني:

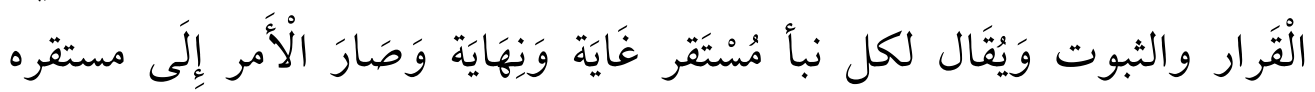

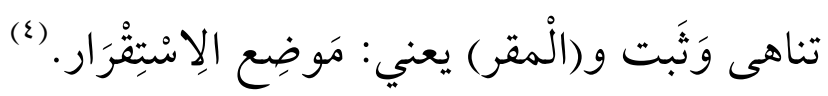

وهي:"النظام الذى شرعه الله أو شرع أصوله ليأخذ الإنسان نفسه فى علاقته بربه وعلاقته

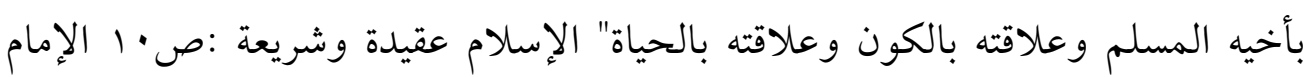

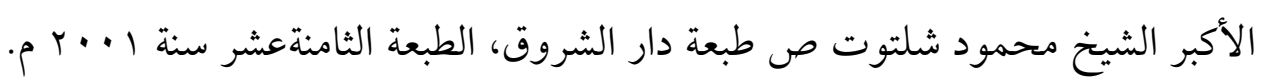

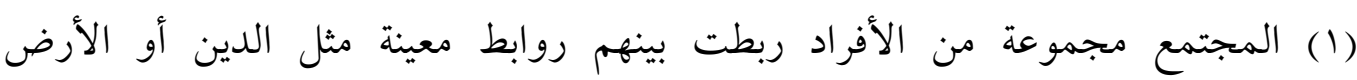

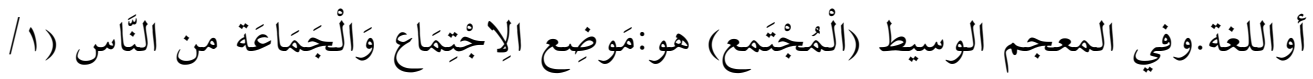

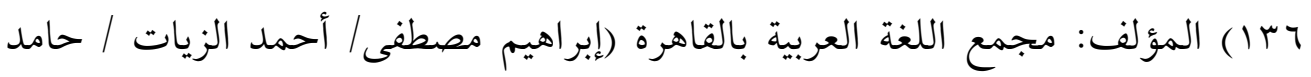
عبد القادر / محمد النجار) الناشر: دار الدعوة.

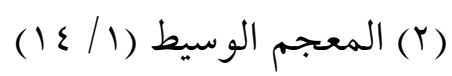

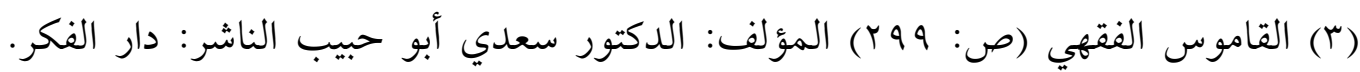

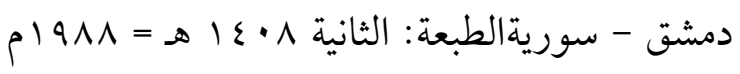

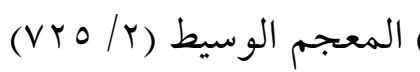


ويطلق رابعة: ويراد منه موضع الاستقرار والاطمئنان. (فالاقترار):

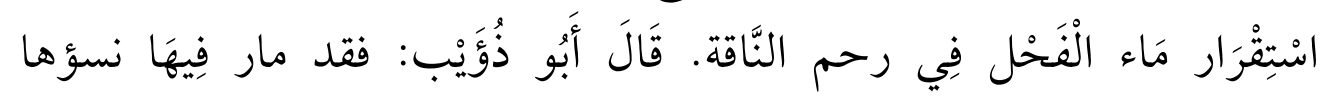

$$
\text { واقترارها (1) }
$$

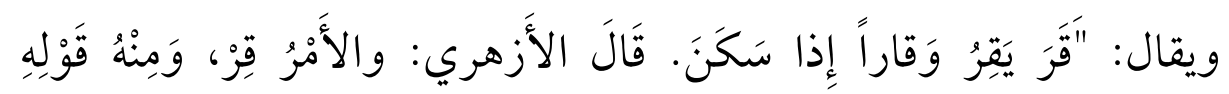

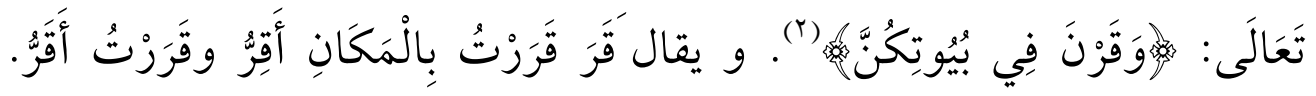

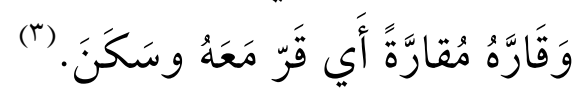

وفي المفردات للراغب الأصفهانى: يقال: قَرَّ في مكانه يَقِقُّ قَرَاراً، إذا

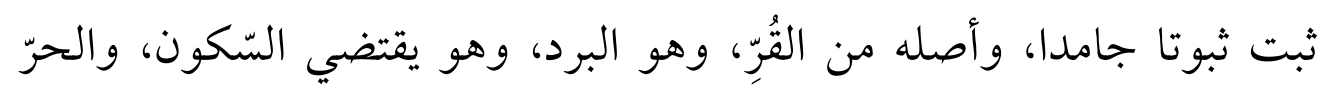

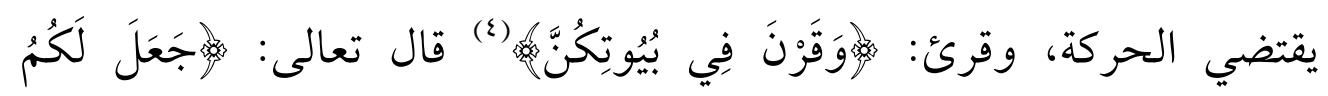

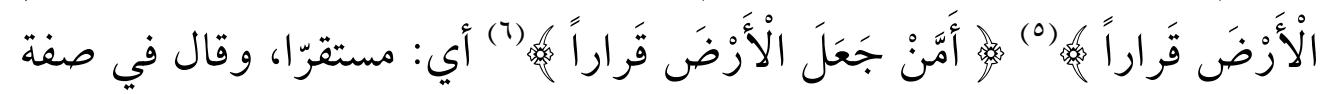

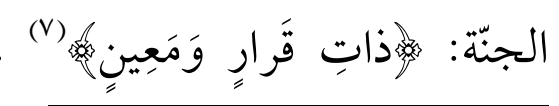

(1) المحكم والمحيط الأعظم (T/ آI ) المؤلف: أبو الحسن علي بن إسماعيل بن سيده

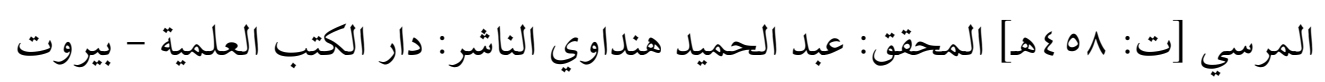

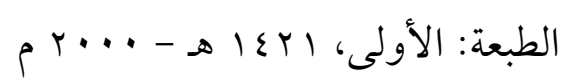

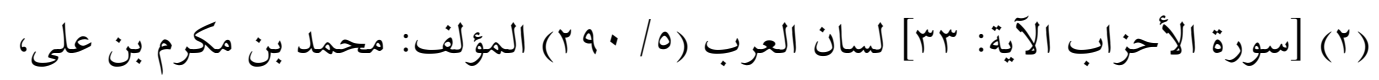

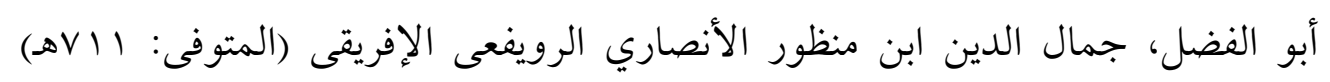

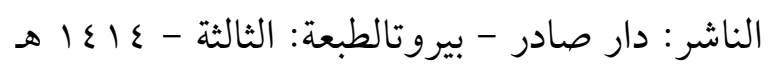

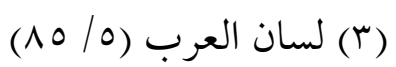

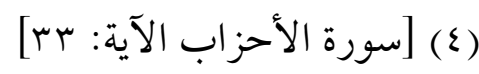

$$
\begin{aligned}
& \text { (0) [سورة غافر الآية: ع7] الآ] } \\
& \text { (7) [سورة النمل الآية: الآ] }
\end{aligned}
$$

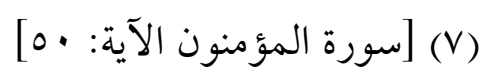




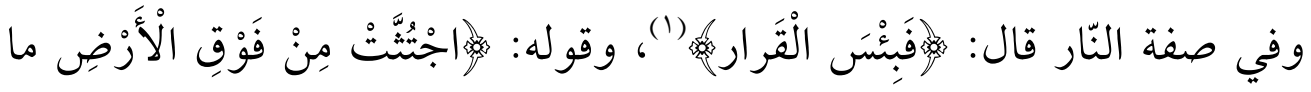

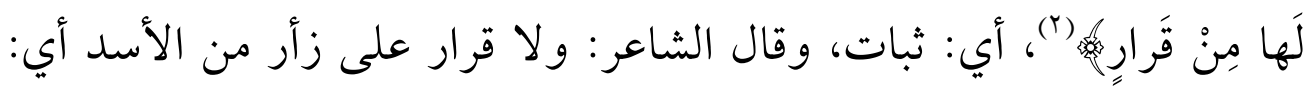

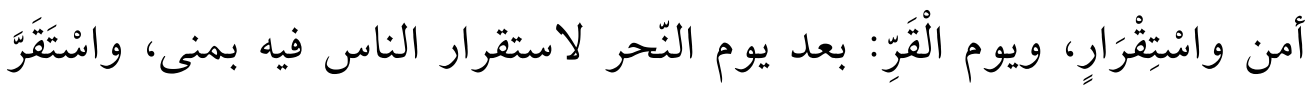

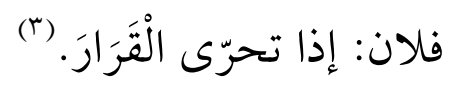

\section{ثانياً : كلمات ذات صلة بالاستقرار:}

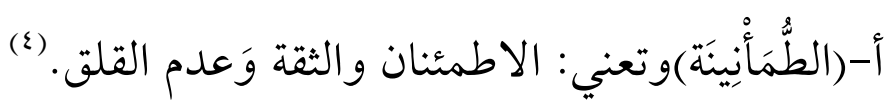

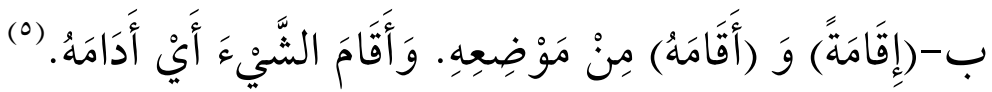

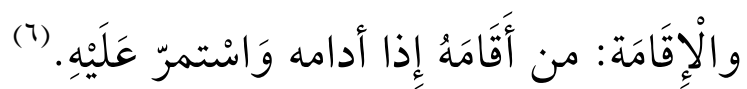

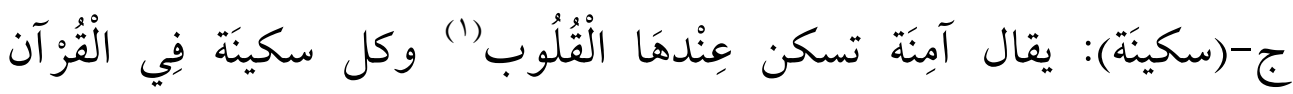

$$
\begin{aligned}
& \text { (1) [سورة ص الآية: •ج] }
\end{aligned}
$$

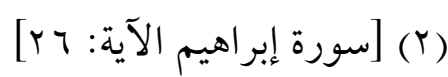

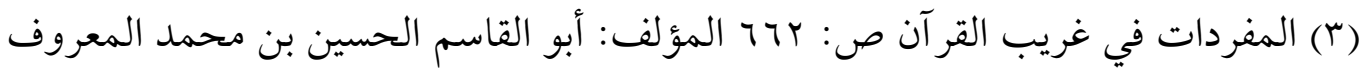

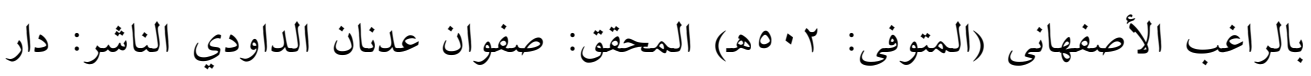

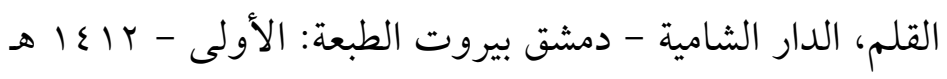

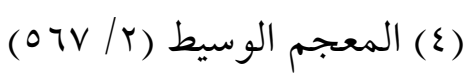

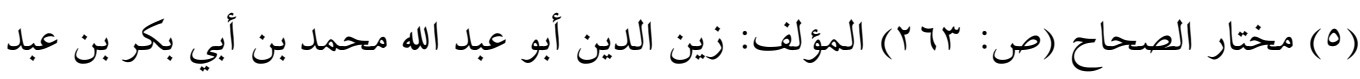

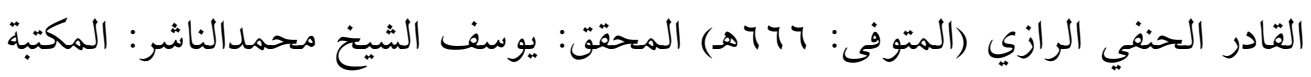

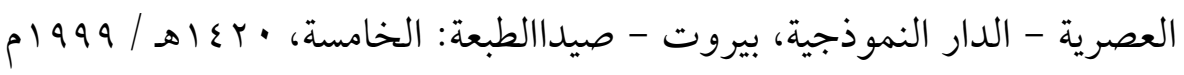

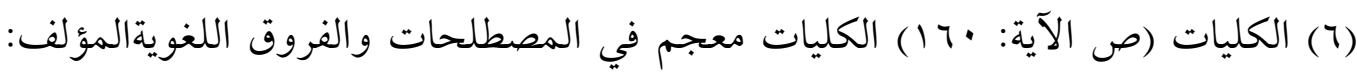

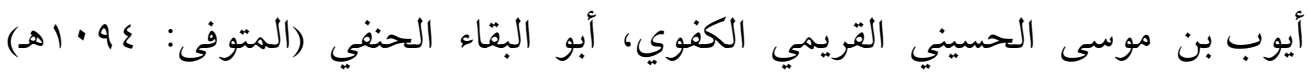

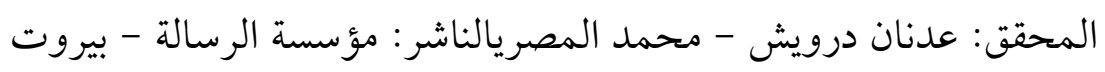




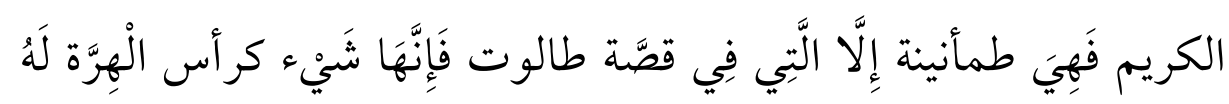

جَنَاحَانِ. (r)

وبالنظر لهذه التعريفات نجد أن الاستقرار يتمحور في كتب اللغة حول

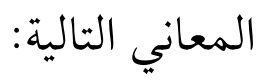

الثبوت، والسكون، والتمكن، و القرار، والغاية، و النهاية، وموضع

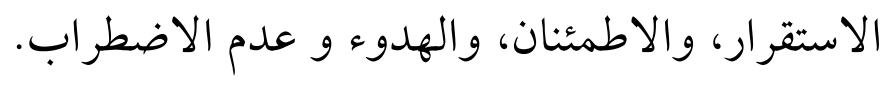

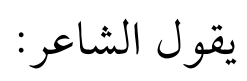

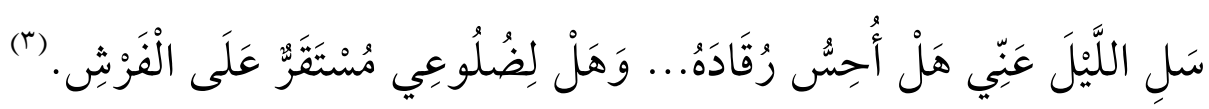

\section{ثالثاً : دلالة كلمة الاستقرار في القرآن الكريــ.}

1- وقدوردت كلمة استقر ومشتقاتها في القرآن الكريم في عدة مواضع

منها:

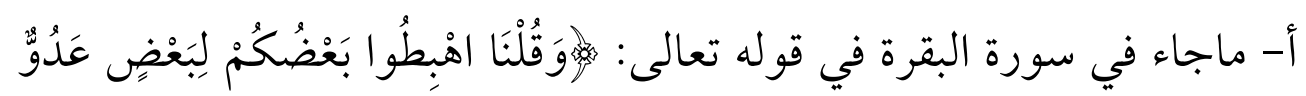

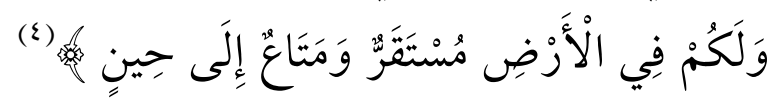

$=$

(1) (1) الكليات (ص: (1) (1)

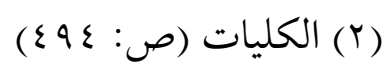

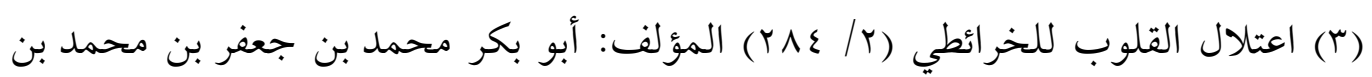

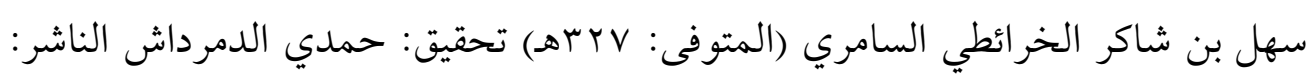

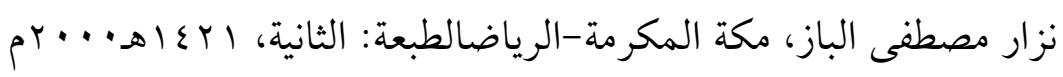

(سورة البقرة الآية: جبـ] 
والمعني: "أنّ لهم في الأرض مستقرَّا ومنز لا بأماكنهم."(1)"

$$
\text { ومعني :(مُسْتَقَرُهُ) أي: "موضع قرار". }
$$

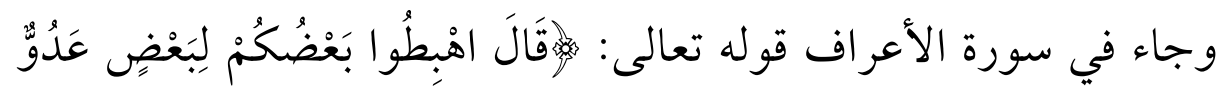

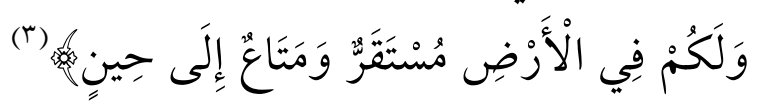

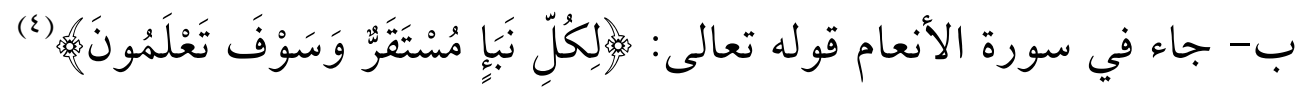
والمعني: "لكل خبر يخبره الله تعالى وقت ومكان يقع فيه من غير خلف

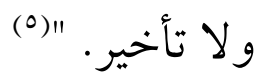

(1) تفسير الطبري = جامع البيان ت شاكر (1/ 9 9\%) المؤلف: محمد بن جرير بن يزيد بن

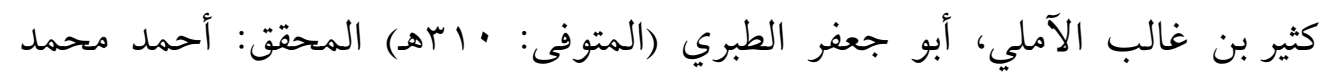

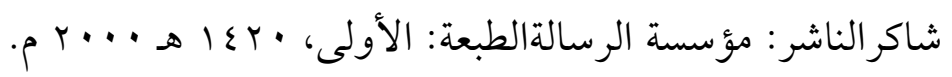

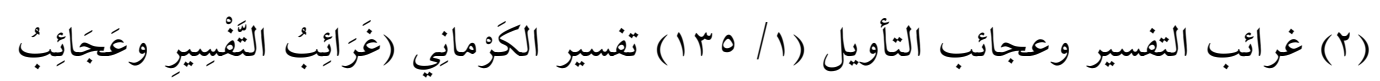

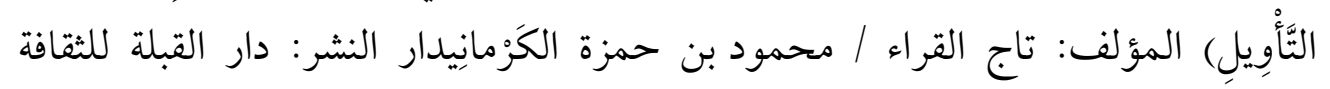

$$
\begin{aligned}
& \text { الإسلامية - جدة مؤسسة علوم القر آن - بيروت }
\end{aligned}
$$

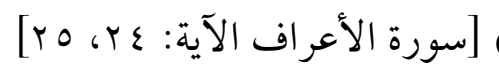

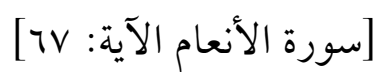

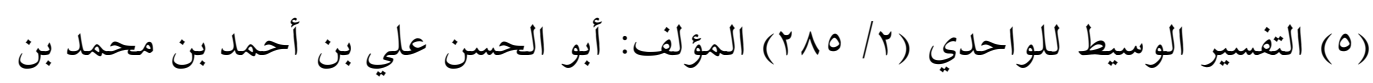

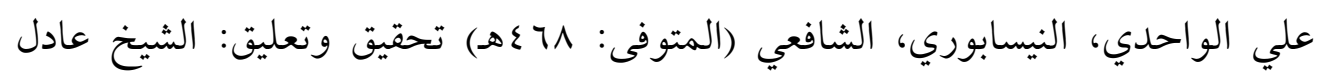

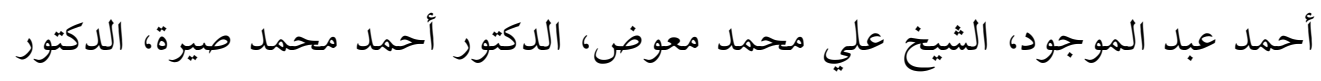

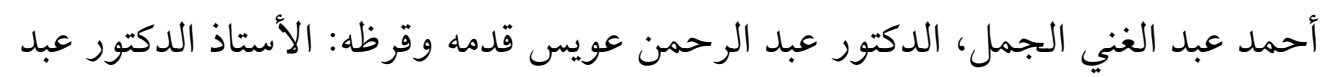

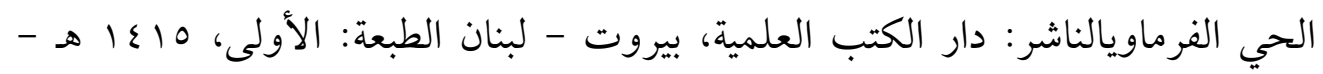


ومعني :لِكُلِّ نَبَا مُسْتَقَرُ أي "غاية يعرف عندها صدقه من كذبه"(1)

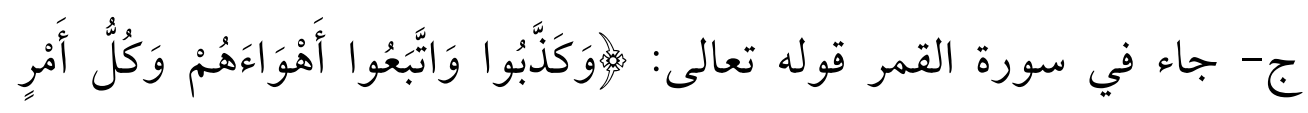
(「) مُسْتَتِرِّر

والمعني: "وكل شيء إلى غاية فالحق يستقر ظاهرا ثابتا، والباطل يستقر

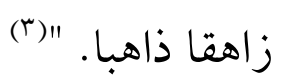

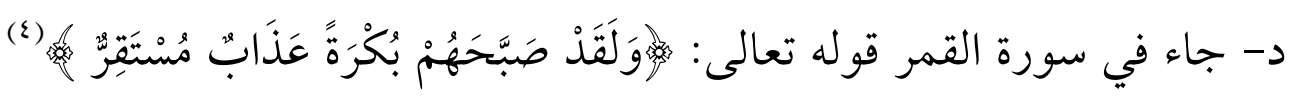

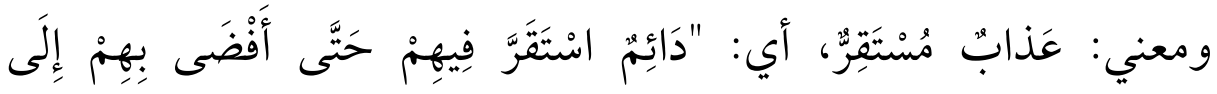

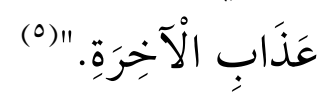

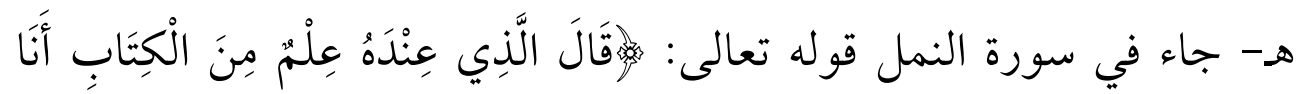

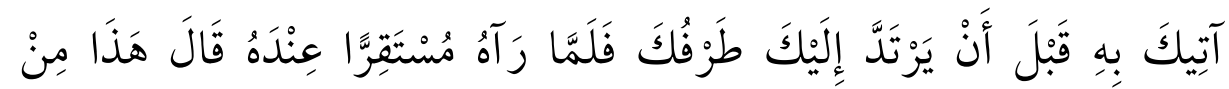

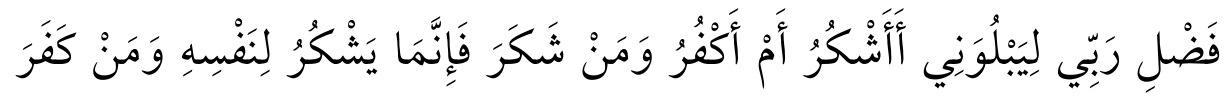

(1) تفسير ابن عطية = المحرر الوجيز في تفسير الكتاب العزيز (r/ ب •r) المؤلف: أبو

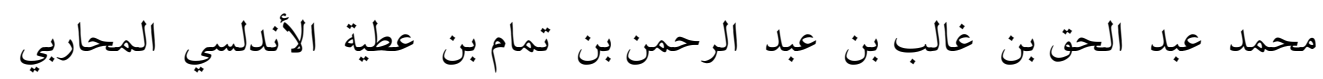
(المتوفى: r عهـ) المحقق: عبد السلام عبد الشافي محمدالناشر: دار الكتب العلمية -

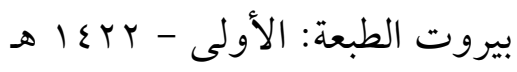

$$
\begin{aligned}
& \text { (r) [سورة القمر الآية: بـ }
\end{aligned}
$$

$$
\begin{aligned}
& \text { (r) تفسير ابن عطية = المحرر الوجيز في تفسير الكتاب العزيز (Y) (Y) (Y) (Y) }
\end{aligned}
$$

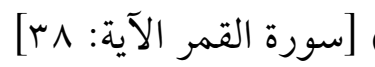

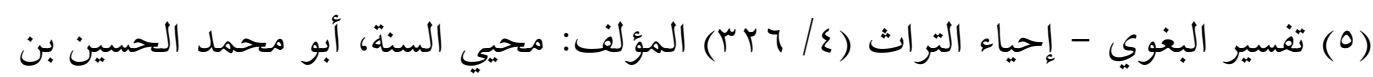

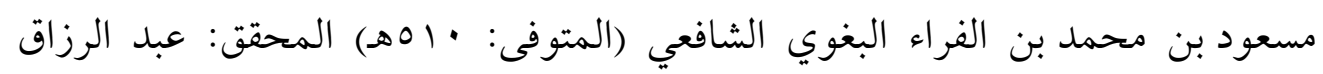

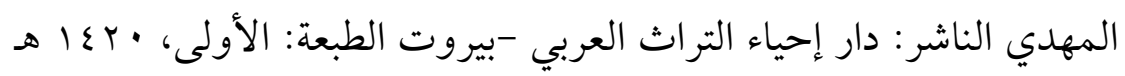




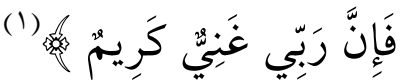

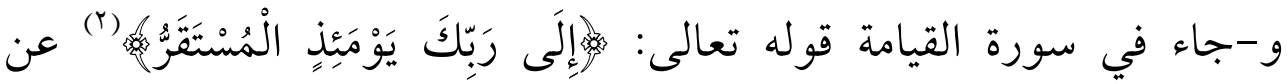

قتادة: أي "المنتهى. "(r)

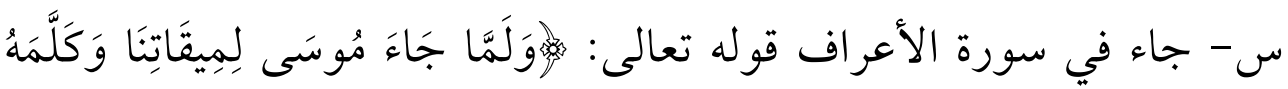

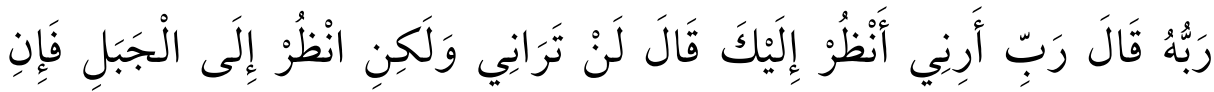

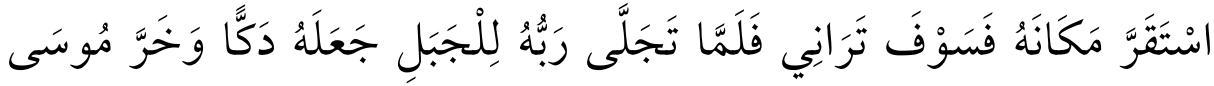

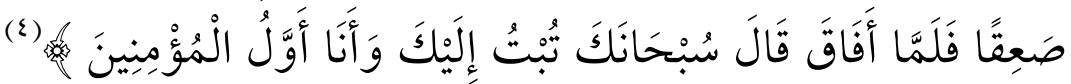

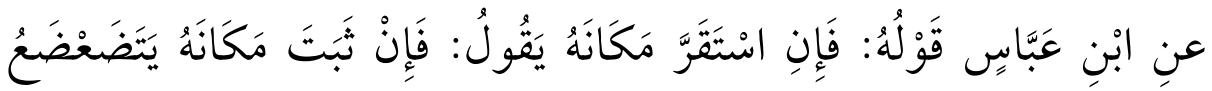

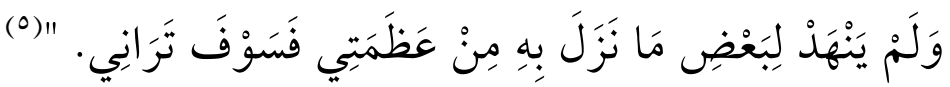
س - جاء في سورة الفرقان قوله تعالى :

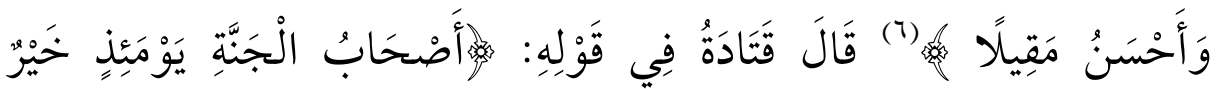

$$
\begin{aligned}
& \text { (1) [سورة النمل الآية: • ع، 1؟] } \\
& \text { (r) [سورة القيامة الآية: r I الهورة }
\end{aligned}
$$

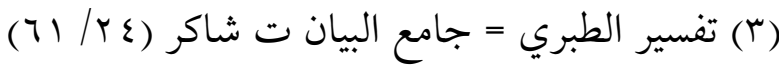

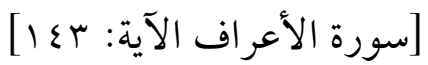

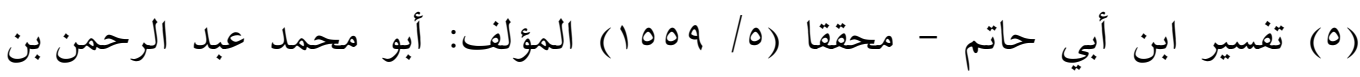

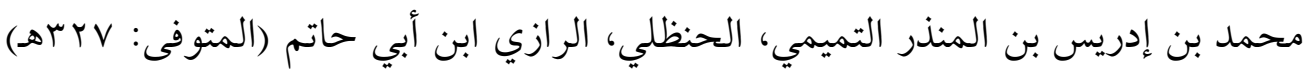

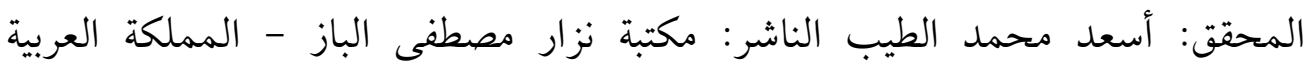

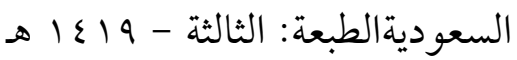

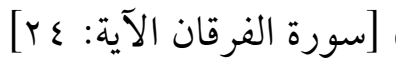




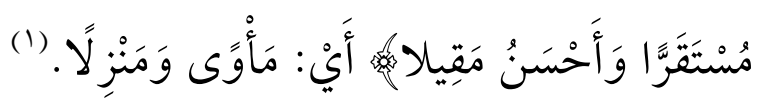

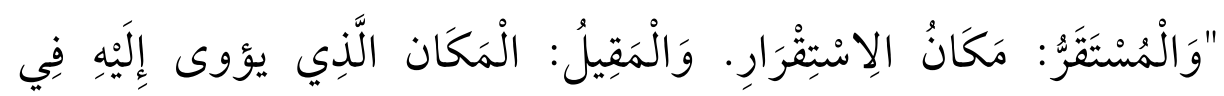

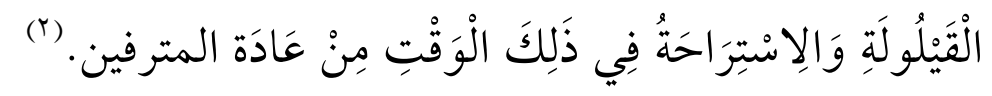

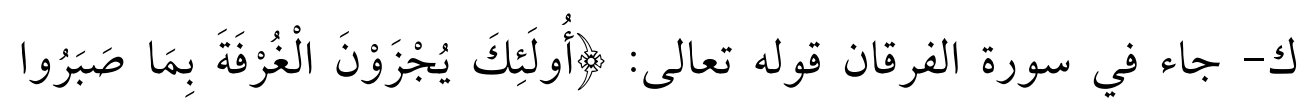

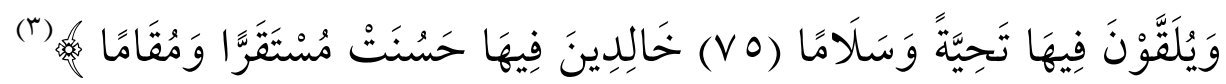

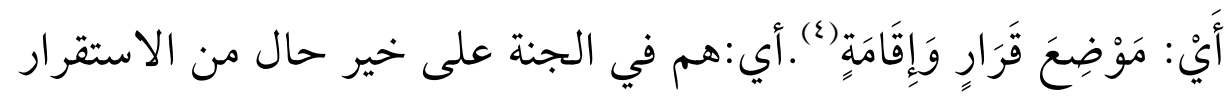

$$
\text { والأمن. }
$$

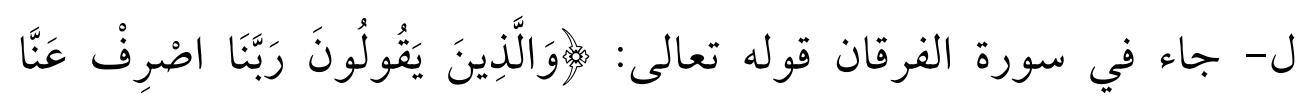

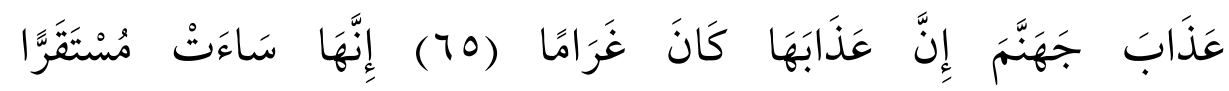

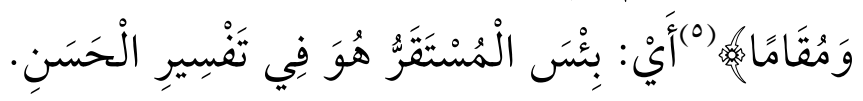

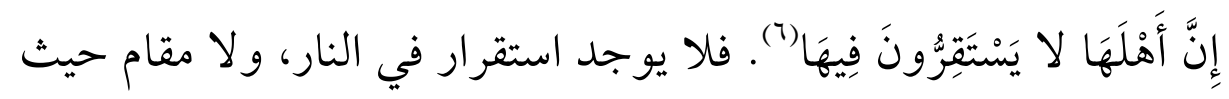

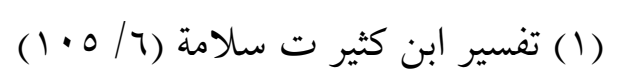

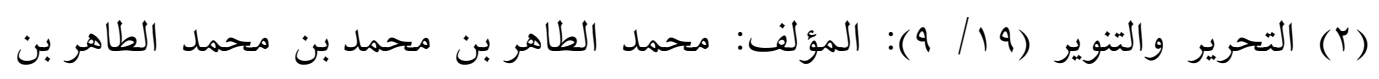

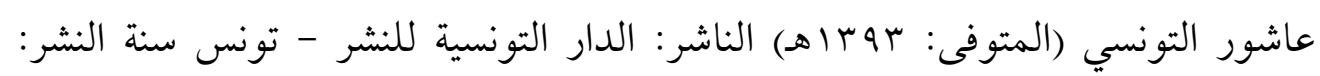

$$
\text { ع ع أهـ }
$$

$$
\begin{aligned}
& \text { (r) [سورة الفرقان الآية: V / V / }
\end{aligned}
$$

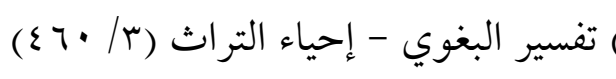

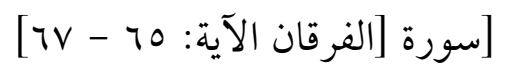

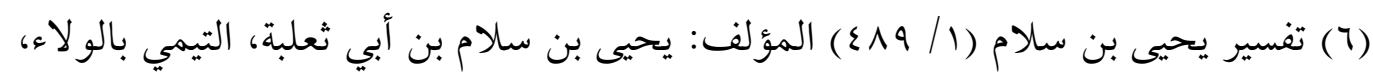

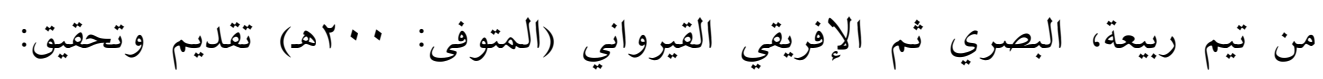
$=$

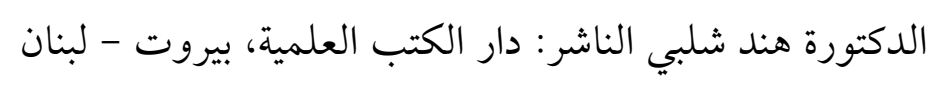


التقلب فيها ليلا و نهار.

ץ-وردت كلمة: (قر)ومشتقاتها في القر آن الكريم في عدة مواضع منها:

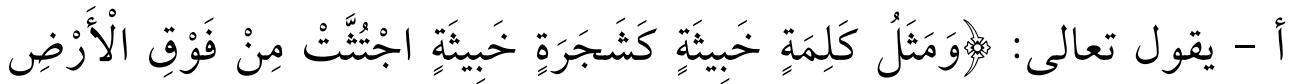

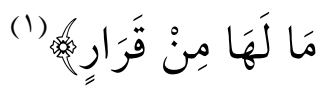

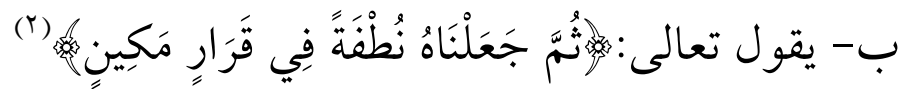

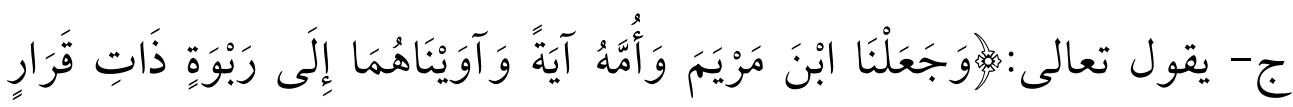

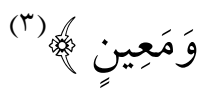

د- يقول تعالى :هَرَفَجَلْنَاهُ فِي قَرَارٍ مَكِينٍ

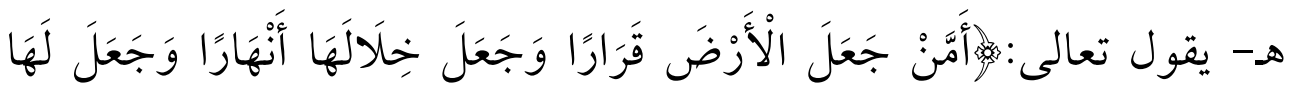

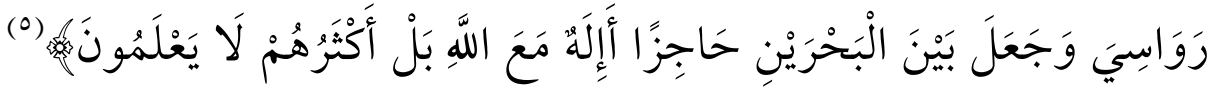

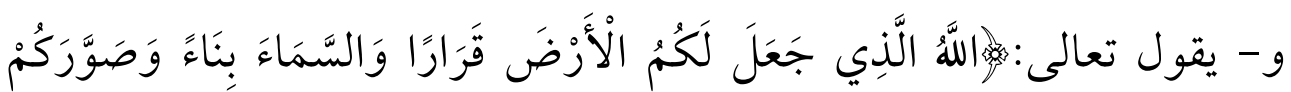

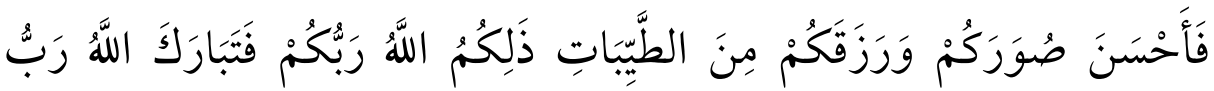

الْعَالَمِينَ

$$
\begin{aligned}
& \text { الطبعة: الأولى، }=
\end{aligned}
$$

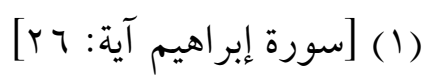

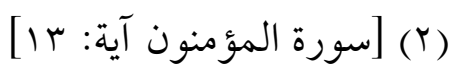

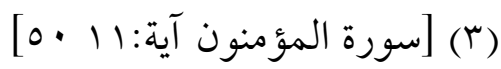

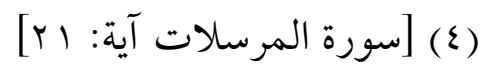

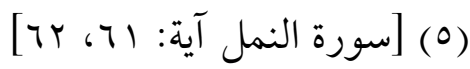

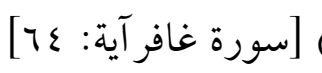




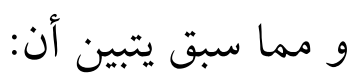

1- الاستقرار ومشتقاته في القرآن الكريم في هذه المواضع يدور حول هذه

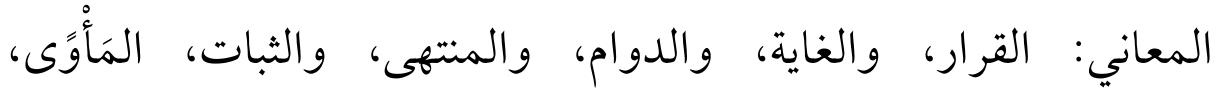

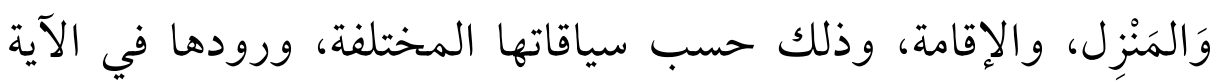
الكريمة وحسبما ذكر المفسرون. ז- كل: " (مستقر) بفتح القاف مصدراً أو مكان استقرار، وبكسرها اتصافاً

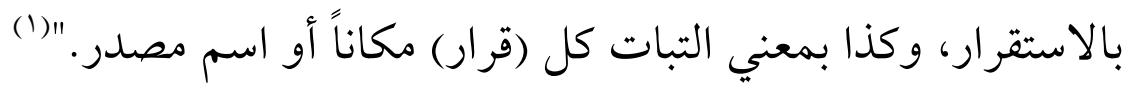
r- الاستقرار في أغلب هذه المواضع جاء في معرض الحديث عن نعمه عزوجل على خلقه في الدنيا أو في الآخرة فمثلاً: أ- الحديث عن أهل الجنة وماهم فيه من النعيم فهم مستقرون مستريحون

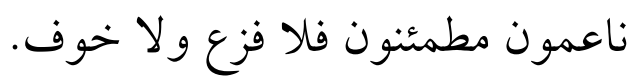
ب- الحديث عن الأرض وكونها مسكناً وقراراً لآدم وذريته من بعده يسكنون فيها، ويستقرون على ظهرها، وهذه من نعم الله علي خلقه. ج- الحديث عن السيدة مريم، ونبيه عيسي عليهما السلام، بأن جعلهما في

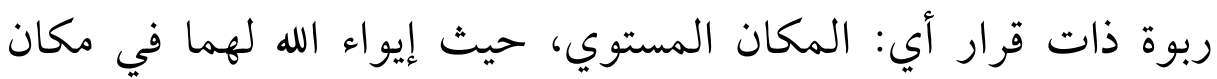
طيب يجدان فيه الرعاية والأمن. إذاً الاستقرار الحقيقي نعمة من نعم الله عزوجل يمن به على من يشاء (1) المعجم الاشتقاقي الموصل للألقاظ القر آن الكريم ص1V0 اد/محمد حسن جبل طبعة

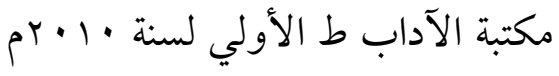


من خلقه أن هم حققوا منهجه واتبعوا سبيله.

\section{رابعاً : مفهوه الاستقرار المجتمعي:}

الاستقرارالاجتماعي قد اصطلح عليه في العلوم الاجتماعية أنه يعني:

"ثات الوضع الاجتماعي الذي لا يطرأ عليه تغيير فجائي أو جذري، بمعنى عدم حدوث تغيير مقصود من قبل المجتمع نفسه أو من خارجه يقوم بتغيير النسق وتوازنه مما يفقده حاله فيخرج على حالة الثبات أو الاستقرار الذي كان عليه إلى حالةعدم الاستقرار. (1) و" الاستقرار الاجتماعي "Social Stability" يختلف معناه من مجتمع الى اخر حسب مستوى التطور الفكري و الاقتصادي لذلك المجتمع، ولكن عموما يمكن القول ان الاستقرار الاجتماعي هو: حالة" الهدوء و السكينة التي تنتاب المجتمع و تجعله قادرا على تحقيق طموحاته و اهدافه نتيجة للتوازن الاجتماعي بين مختلف القوى الاجتماعية الفاعلة. كما يمكن ان نعرف الاستقرار الاجتماعي في حالة المجتمعات ذات

$$
\text { الهويات الفرعية المتعددة: }
$$

حالة العمل و التفاعل الايجابية غير المقيدة بين هذه المجتمعات الفرعية دون وجود معوقات طبيعية او مصطنعة داخلية او خارجية و دون وجود قوة قهرية

$$
\text { تجبر هذه المجتمعات على العمل و التفاعل معا. (r) }
$$

(1) القاموس الألفبائي يحيى بن الحاج الجيلاني وآخرون، ص.rrr طبعة الأهلية للنشر،

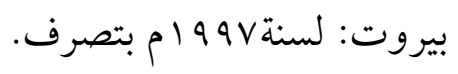
http://vision4iraq.blogspot.com.eg/2015/09/blog-post.html (r) $=$ 
و الاستقرار الاجتماعي يعني:انتظام حركه المجتمع في أنماط معينه، على وجه يتسق مع السنن الالهيه الكلية والنوعية، التي تضبط حركه المجتمع، وهو ما يتحقق من خلال المشاركة وينتفي في حاله الصراع. (1) و يمكن تحديد مفهوم الاستقرار المجتمعي بعد هذا العرض والنظرة

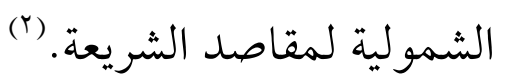

بأنه يعني:حالة من السكينة والهدوء والثبات والتعايش بين أفراد

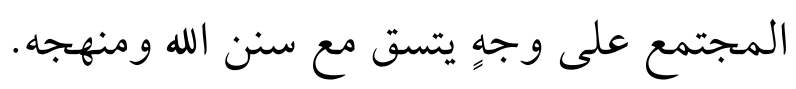
ولذلك فإن العناصر الرئيسة للاستقرار الحقيقي (זمن خلال ماسبق تكمن في: العنصر الأول: المنهج. وأعني بذلك:تحقيق المنهج الرباني الفريد المتكامل سواء على مستوي

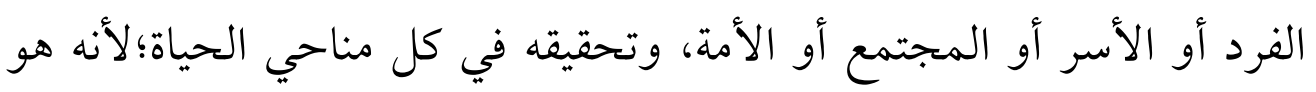

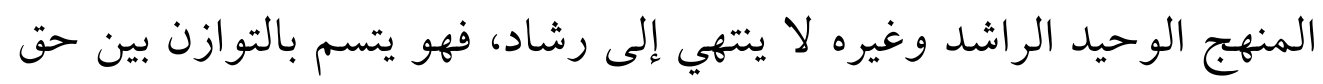

الرابط: مقال بعنوان دور مؤسسات المجتمع المدني في الاستقرار الاجتماعي. https://drsabrikhalil.wordpress.com/2014/12/03/\%D8\%A7\%D9\%84 الرابط: مقال بعنوان الحفاظ على الاستقرار في المنظور التشريعي الاسلامى.

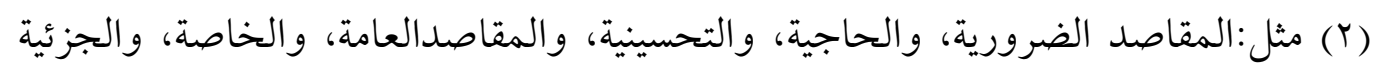
وكل ذلك مفصل في كتب المقاصد. (r) لأن: هناك استقرار هش ومزيف لا يمكن أن يستمر و يصمد وهو: الذي لا يقوم على هذه العناصر . (ب) 
الجسم وحق الروح، وبين الدنيا والآخرة، وكذلك يتسم بالشمول والعموم حيث جاء لتنظيم علاقة الإنسان بربه، وبنفسه، وبالمجتمع الذي يعيش فيه، و كذلك يتسم بالواسطية، والو اقعية.

فاله هو خالق الإنسان وهويعلم ما يصلحه يقول تعالى: مارغالَا يَعْلَمُ مَنْ

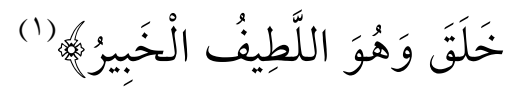

ولذلك لما أنزل الله الأبويين إلي الأرض أراد لهم الاستقرار والأمن

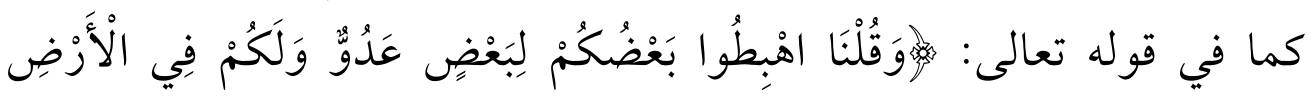

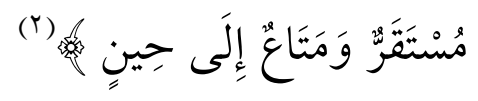

وجعل سبحانه للاستقرار مقومات مادية ومعنوية فالمادية مثل: تذليل

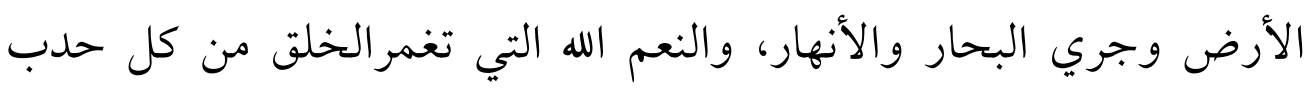

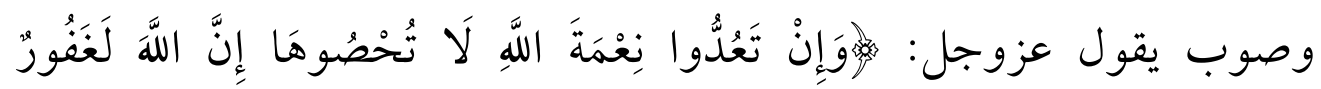

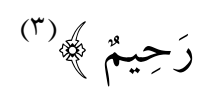

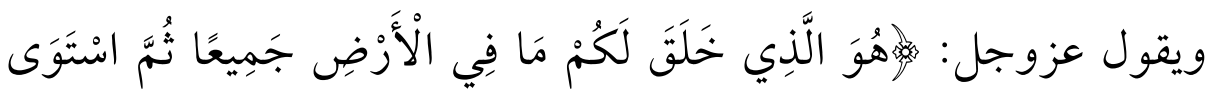

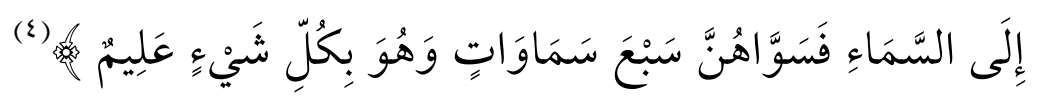

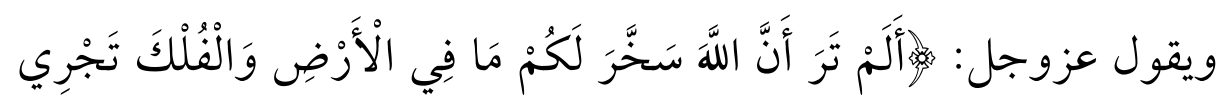

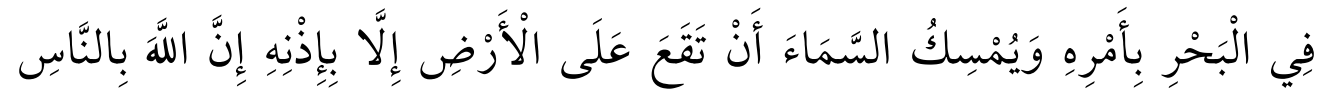

$$
\begin{aligned}
& \text { (1) [سورة الملك الآية: ع 1] }
\end{aligned}
$$

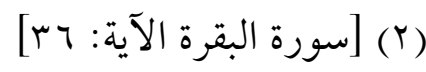

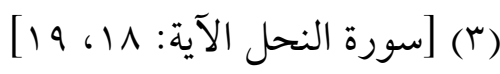

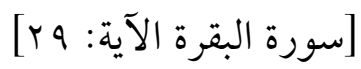




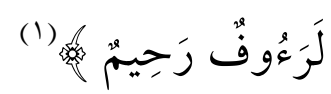

وجعل له كذلك مقومات معنوية: مثل: إرسال الرسل، وإنزال الكتب،

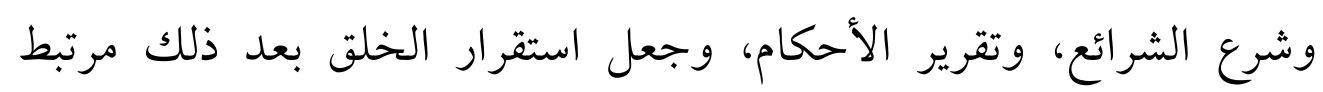
بمدي ارتباطهم بالمنهج الإلهي والعمل في نطاق ما يرضيه عزوجل، فكلما تحققوا بالمنهج الرباني كلما تتحقق لهم الاستقرار الحقيقي على هذه البسيطة.

العنصر الثاني: التعايش.

و أعني بذلك: التعايش بين أفراد المجتمع بغض النظر عن اللون أو الغه

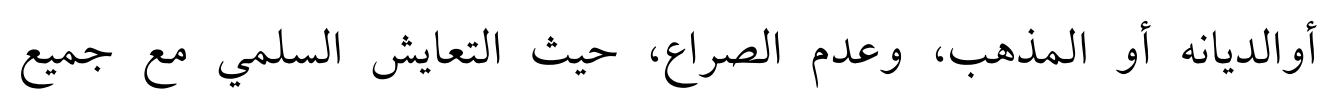

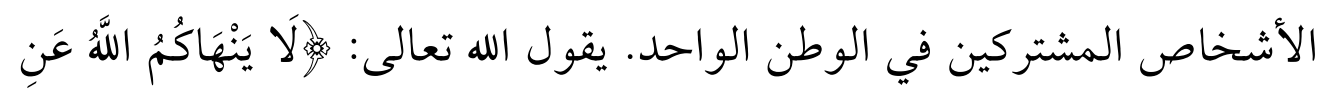

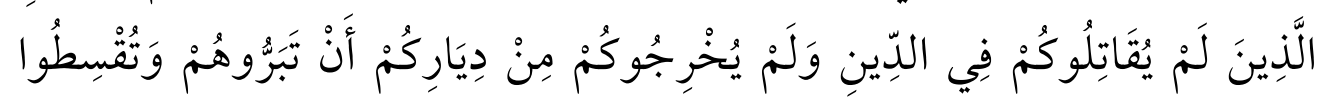

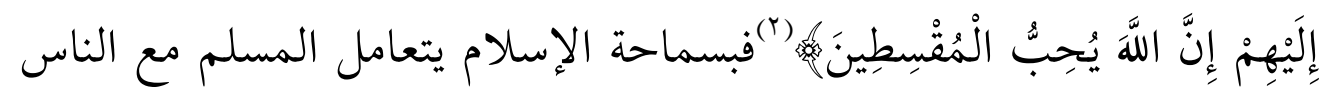

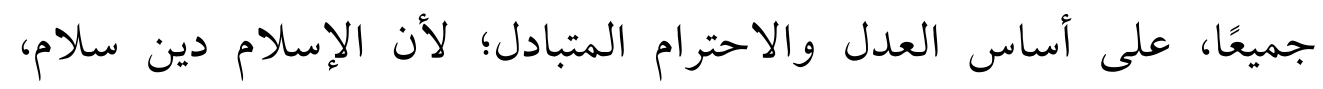
وعقيدة حب، لايرغب في الخصومة مع أحد من البشر فهو يسالم من سلامه.

\section{العنصر الثالث: الحماية.}

وأعني بذلك: حماية الوضع الاجتماعي من أن يطرأ عليه تغيير فجائي أو جذري، يفقده توازنه فيخرجه من حالة الثبات والسكون الذي كان عليها إلى حالة القلق والاضطراب وربما التقاتل.

$$
\begin{aligned}
& \text { (1) [سورة الحج الآية:70] } \\
& \text { (r) [سورة الممتحنة الآية: 1) }
\end{aligned}
$$


وحماية الوضع الاجتماعي تكون بالحفاظ على النسيج المجتمعي من كل الآفات المادية، والمعنوية، والتي تؤثر ثأثيراً سلبياً على استقراره، وذلك برفض كل أشكال: الانحلال في العقائد، والأخلاق، ورفض كل أشكال الظلم، والفساد، وكل أشكال العنصرية، والتعصب، والعنف، والغلو، والتطرف، فليس في الشريعة تطرف أو إرهاب(1) إنما أحكامها تحمل للناس الوسطية والاعتدال وترفض كل أشكال الإرهاب والتقاتل، أو مجرد الدعوة إليه أو التحريض عليه، لإن هدف الشريعة هو: الوصول إلي مجتمع أمن مستقر يخلو من النزاعات، وإن وقع فيه نزاع يحل بطريقه سلمية.

ولقد حققت الشريعة بمقاصدها هذه العناصرالثلاثة وذلك بحفظها للضروريات، وجلبها للمنافع ودفعها للمضار.

\section{G(2)}

(1) صدر في تحديد الإرهاب بيان عن مجمع الفقه الإسلامي في رابطة العالم الإسلامي

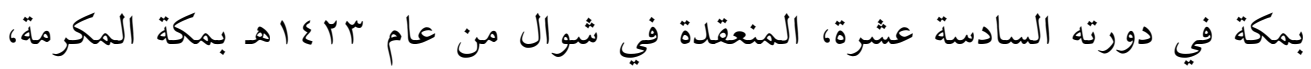

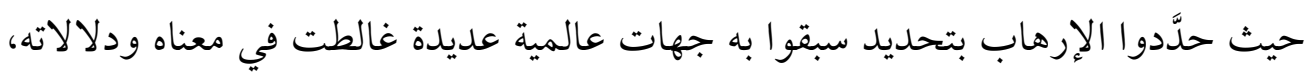

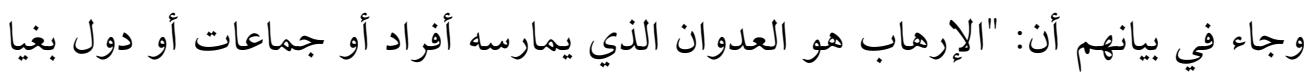
على الإنسان في دينه، ودمه، وعقله، وماله، وعرضه، ويشمل صنوف الإنه التهدوال التخويف والأذى النى

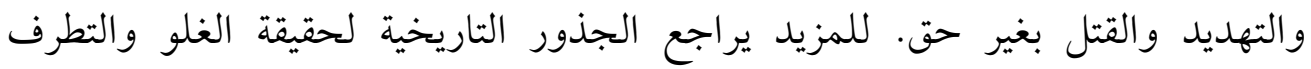
والإرهاب والعنف (ص: با، بترقيم الشاملة آليا) المؤلف: علي بن عبد العزيز بن علي الشبل الناشر: الكتاب منشور على موقع وزارة الأوقاف السعودية بدون بيانات. 


\section{المطلب الثاني}

\section{أهمية الاستقرار وخطورة الإخلال.}

\section{أولا : أهمية الاستقرارالمجتمعي.}

الاستقرار حاجة فطرية لكل إنسان وهو الحالة الطبيعية للحياة، وغيابه حالة معاكسة للفطرة، فالإنسان اجتماعى بطبعه يحتاج إلى مجتمع يحيط به ويستقر فيه ليحقق فيه إحتياجاته المادية والروحية والثقافية والأخلاقية، ولذلك فإن هناك أهمية كبيرة للاستقرار، وعندما نريد أن نحدد بعض جوانب

$$
\text { هذه الأهمية فنجد أنه: }
$$

ا- يحمي المجتمع من الفتن والقلاقل، حيث ينبذ الصراع، ويوفر المناخ الملائم لكي يعيش الجميع في سلام، ويتحويل منحى الاختلاف والاشتباك بين أفراد المجتمع الى الحوار المشاركة والبناء والتعمير. r- يحقق الأمن والسلام، وهو من المطالب الضرورية للإنسان أوهو ذو أهمية لا تقل عن المطالب الأخرى كالغذاء والكساء، حتي يستطيع الإنسان أن يقوم بممارسة حياته اليومية على الوجه الأمثل، وقد أمن الله تعالى للإنسان حاجته الضرورية التي تعينه على الاستقرار فقال تعالى:

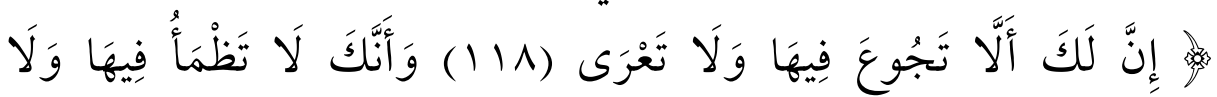
تَضْحَى به. (1) وقد انتبه الإنسان إلىى ضرورة الأمن منذ بداية حياته فكان البعد عما يهدد حياتة وكان رفضه لكل أشكال الجريمة والعنف، و"قد 
أثبتت الدّراسات العلميَّة في مجال العلوم الاجتماعيَّة أنَّ حاجات الإنسان الأساسيَّة والأرقى في سلّم الحاجات الإنسانيَّة لا يمكن لها أن تتحقّق ما لم يتحقق أولاً للإنسان حاجته للأمن؛ حيث يشير هرم الحاجات الإنسانيَّة الذي وضعه عالم النفس الأمريكي أبراهام ماسلو

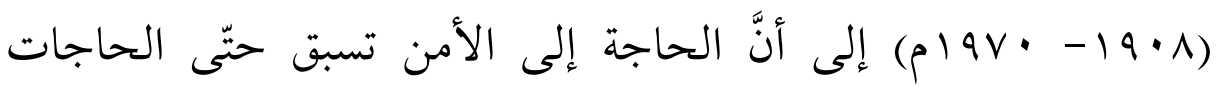

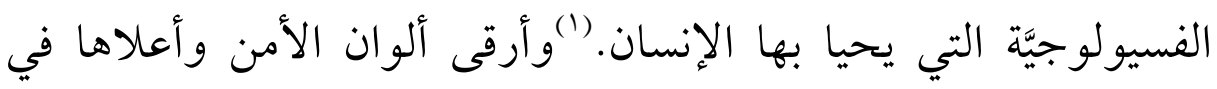

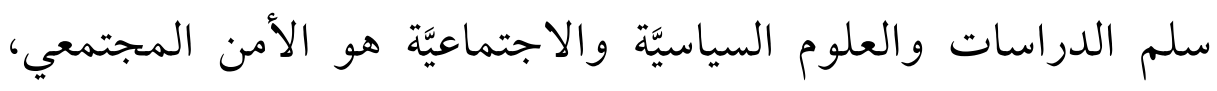
فهو ذلك الجانب من الأمان الذي يرتبط بالمجتمع ككل، ويرتبط أيضًا بالكثير من الممارسات والمقومات التي إن توافرت؛ فإنَّ ذلك يكون وئرنيط بمثابة شهادة على تطور ورقي هذا المجتمع. r- يعين علي التقارب والتفاهم والتسامح والتضامن بين الناس. ع - يساعد علي إعمار الكون. فمن مهام الإنسان: عمارة هذا الكون، وهذه العمارة تطلب الاستقرار ولا يمكن أن تتم عمارة إلا عن طريقه. ج- يحمي النسيج الإجتماعي من التمزق. - يحافظ علي المجتمعات ويحمي الحقوق والواجبات. 1- يعمل علي إيجاد عالم إنساني متعاون. 9- يحقق كر امة الإنسان وحقوقه.

(1) مقال بعنوان:الأمن المجتمعي في الإسلام.. رؤية سياسيَّة الرابط https://basaer-online.com/2011/09/2011-09-21-20-49-35 
• 1- يحافظ على الضروريات اللازمة للناس، من الدين والنفس والعقل

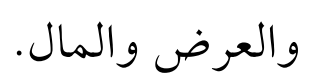

1 - 1 يطهر المجتمع من الفساد والرذائل والفو احش. r ا - يطهر المجتمع من الأمراض والأدواء الظاهرة والباطنة. rا - يوحد الصف ويجمع الكلمة.

ع ا- يحقق الأخوة الإنسانية. ولا شك في أن الأخوة الإنسانية قد تشكّل

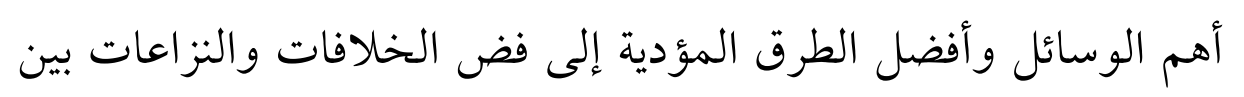

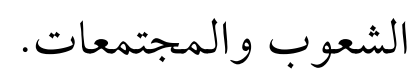

10 - يحقق التعاون والتكافل والتضامن. 17

IV يحقق انشراح الصدر وطمأنة القلب وإراحة البال. 11- يحقق الآثار الاجتماعية والإنسانية وتنميتها على نحو الأخوة و التضامن.

9 ا - يحقق أواصر التضامن والتآلف والتراحم والتواد بين أبناء المجتمع. • r- القدرة على المشاركة في الوطن بالر أي والجهد والبناء.

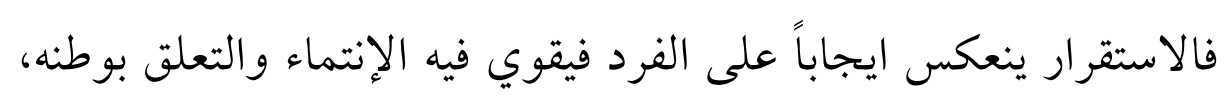
فيقدم كل جهد في تطويره والدفاع عنه. ا آ- القدرة على تحقيق الأهداف والطموحات. 


\section{ثانياً :خطورة الإخلال باستقرار المجتمع.}

إن الإخلال باستقرار المجتمع ليسبب كثيراً من المشكلات، بل أن

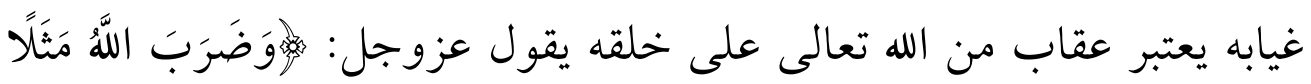

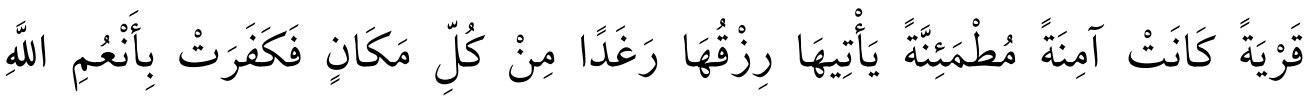

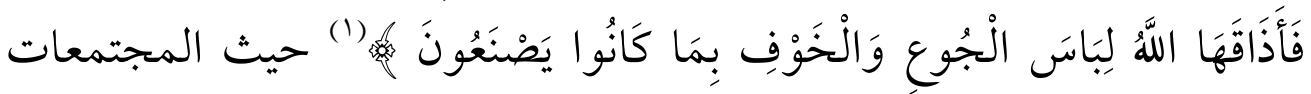
البشرية بلا استقرار: - مان

$$
1 \text { - تسودها الفرقه والاختلاف. }
$$

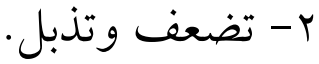

$$
\text { r- تهلك وتفسد. }
$$

ع - يضيع الحق فيها.

ه- لا تجد فيها تقارباً ولا تعايشاً.

7- يسودها الخراب و الدمار.

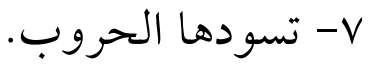

1- تضيع فيها القيم و المبادئ.

9 - تضيع فيها الحقوق.

• 1 - تكثر فيها الجريمة.

1 - تنشأ فيها الصراعات المذهبية والطائفية والعرقية.

$$
\text { (1) [سورة النحل الآية: rII] }
$$




$$
\text { r ا - يسودها الاضطر اب والخوف. }
$$

rا - يظهر فيها الفساد والرذائل الفواحش وجميع الأمراض والأدواء الظاهرة و الباطنة.

ع - تكثر فيها التجاوزات والاعتداءات ويذهب منها الأمن ويحل فيها

$$
\text { الخوف و الرعب. }
$$

0 1-تصبح حياة الناس كلها حيرة، وقلق، واضطراب، و تردد وتخبط. 7 ا 1 - عدم القدرة على تحقيق الأهداف والطموحات الفردية والجماعية. IV

حيث تهدرالدماء بالقتل والتعدي، وتضيع الأموال بالسرقة والنهب، وتنتهك الأعراض، وإذا انتهكت حقوق الناس ومصالحهم فهذا يعني الدمار وشيوع الفوضي وبالتالي ضياع الأمن والسلم وهذا يعني كله ضياع

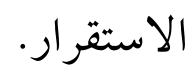

G(2) 


\section{المبحث الثاني}

مقومات الاستقرارالمجتمعي.

$$
\begin{aligned}
& \text { المطلب الأول: تحقيق الإيمان. } \\
& \text { المطلب الثاني: تحقيق الأخوة والترابط. } \\
& \text { المطلب الثالث: تحقيق العدل. } \\
& \text { المطلب الرابع: تحقيق التعايش السلمي. } \\
& \text { المطلب الخامس: تحقيق الوسطية والاعتدال. }
\end{aligned}
$$




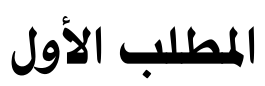

\section{تحقيق الإيمان.}

الاستقرارالمجتمعي له مقومات لايمكن أن يتحقق إلا بتوافرها في

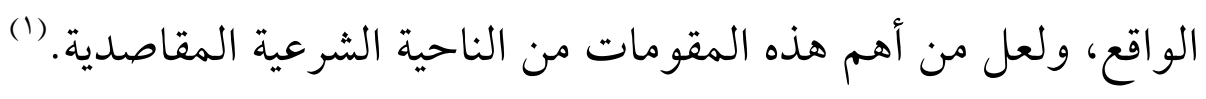

الإيمان بالله والعمل الصالح فهما سَّر الحياةَ الطيبة، وهما من أعظم

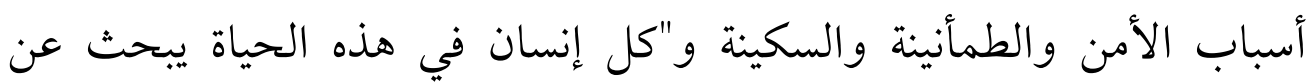

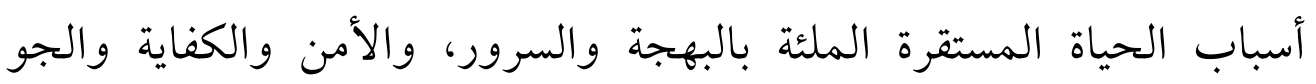

النظيف، والمظهر الجميل، والحياة الطيبة هدف جعله الله جزاء الإيمان. (r)

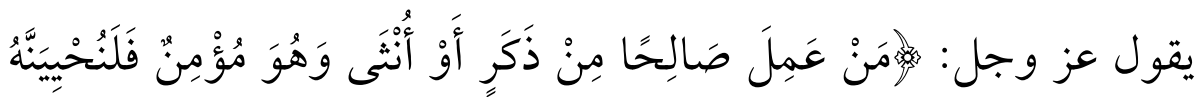

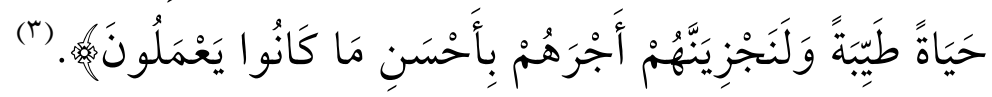

فالشرط الأول لتحقيق نعمة الاستقرار والأمن كما حدّدتها هذه الأية

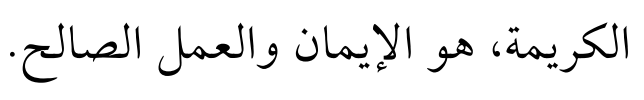

فالإيمان يطهر النفس وينمي فيها معاني الخير ويعالج ما يعتريها من

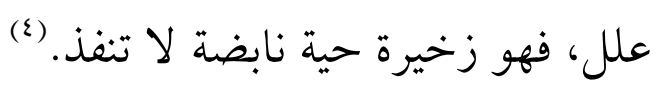

(1) للأنه: يو جد مقومات أخري عند علماء الاجتماع وعلم النفس.

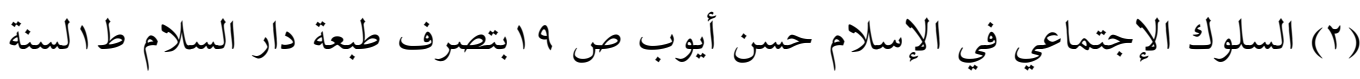

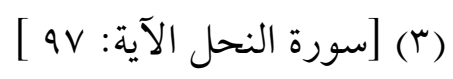

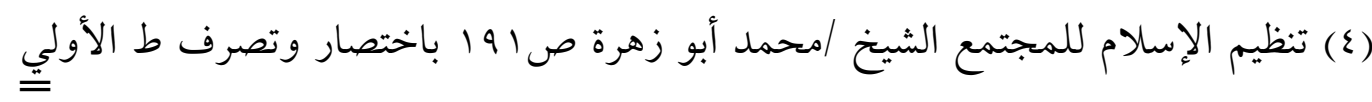


فتحقيقه يحمل الإنسان على الاستعلاء على نفسه الأمّارة بالسوء،

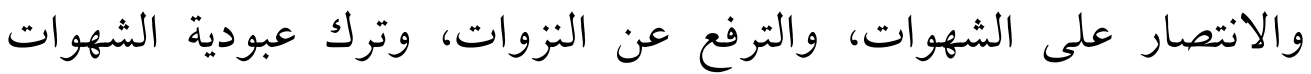

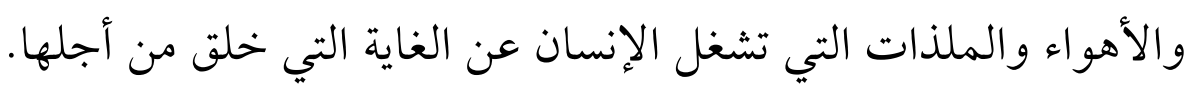

فهو نقطة تحول يرتقي فيها الإنسان إلى معرفة الله ومحبته وطاعته،

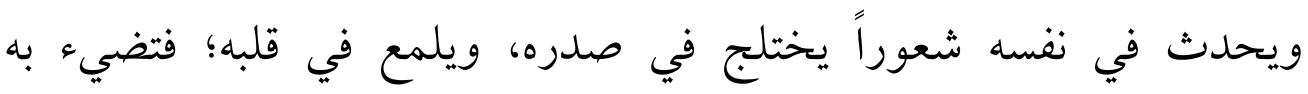

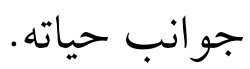

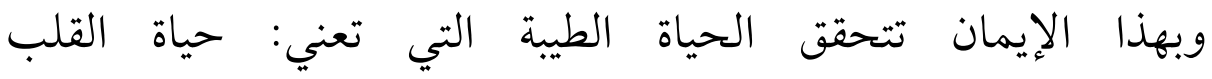

وهانئنه،وانشراح الصدر!ولذلك كان للإيمان ثمار على النفس حيث يورث:

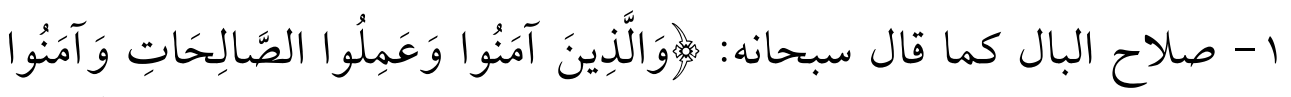

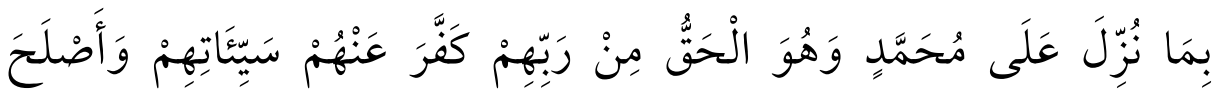

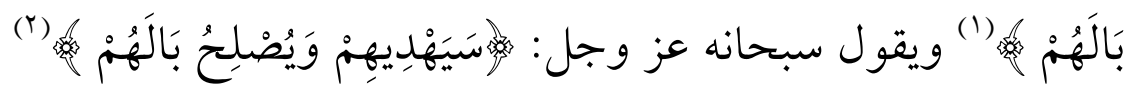
r- يورث السكينة والتي هي ينبوع السعادة الحقيقية، حيث يقول سبحانه:

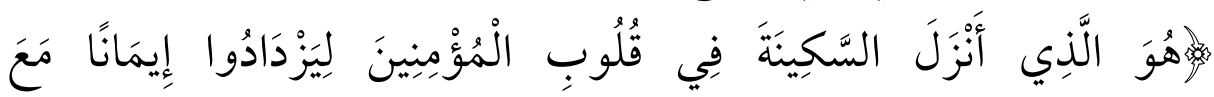

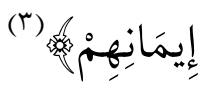

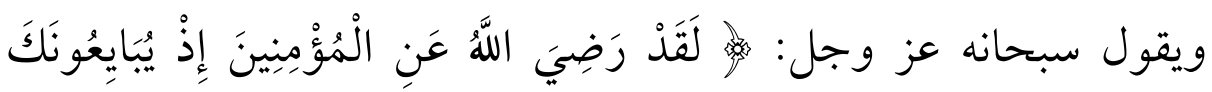

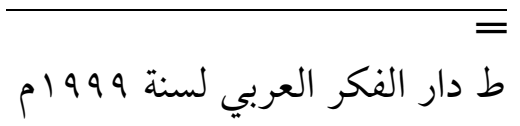

$$
\begin{aligned}
& \text { (1) [سورةمحمد الآية: r، بـ] } \\
& \text { (r) [سورة محمد الآية: } 0 \text { ] }
\end{aligned}
$$

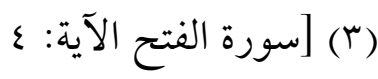




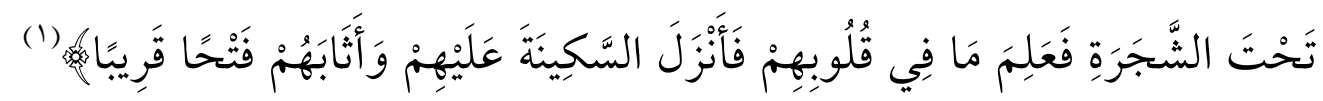

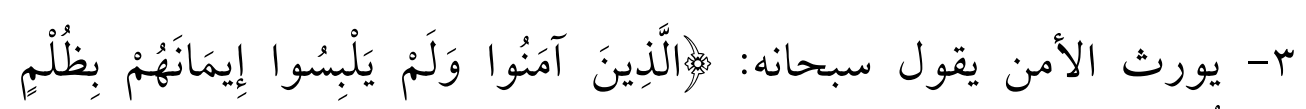

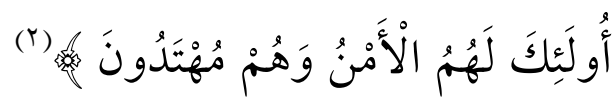

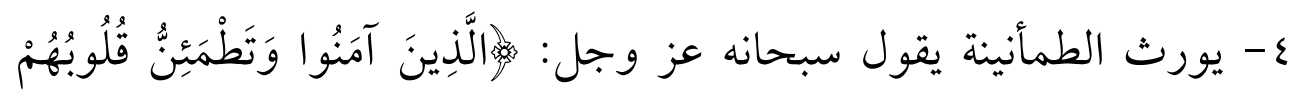

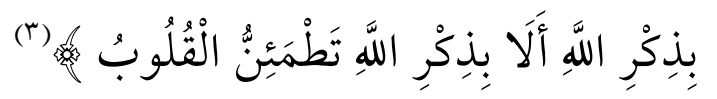

ه- ينزل البركة ويزيد الرزق يقول سبحانه عز وجل : آهَوَلَوْ أَنَّ أَهْلَ الْقُرَى

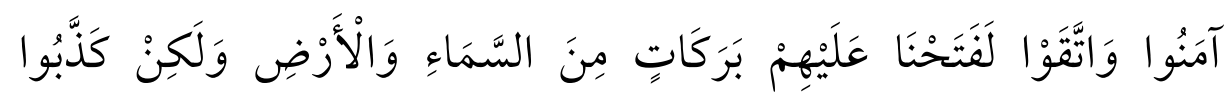

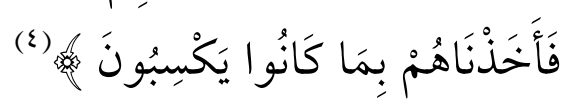

7- يورث السعادة بكل معانيها كما فسرها ابن عباس -رضى الله عنهما- في

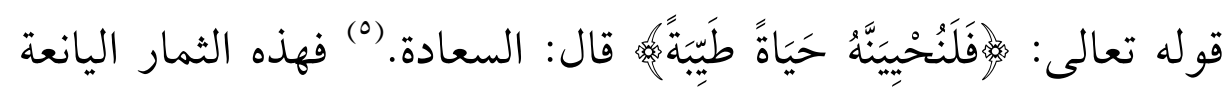
للإيمان من صلاح البال، والسكينة، والأمن، والطمأنينة والبركة، والسعادة، هي الروافد الحقيقية للاستقرار المجتمعي.

فالإيمان بالله والارتباط به هو وحده الذي يصح أن يكون بداية إصلاح

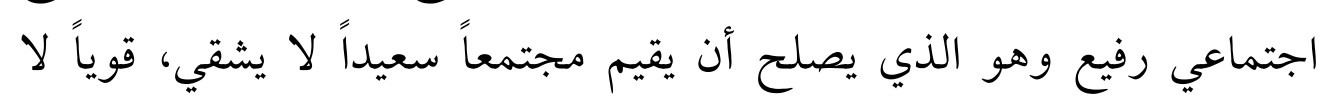

$$
\begin{aligned}
& \text { (1) [سورة الفتح الآية: 111) }
\end{aligned}
$$

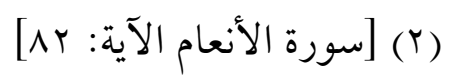

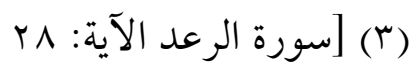

$$
\begin{aligned}
& \text { (ع) [مورة الأعراف الآية: } 97 \text { ] }
\end{aligned}
$$

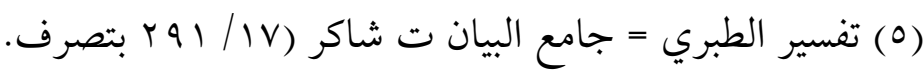




\section{يقهر، آمناً لا يفزع ولا يخاف. (1)}

ولذلك صنع الإيمان بيوتاً سعادتها لا توصف، وأنشاء جنات معروشات من المجتمعات المستقرة، وحضارة الأمة المسلمة وتاريخها الطويل خيرشاهد على ذلك على مر العصور والدهور. وهذا نموذج تحقق بالإيمان ومقتضياته فكانت نفسه وبيته كشجرة طيبة

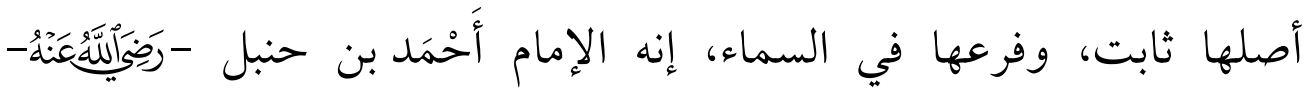
يلخص لنا حقيقة الاستقرار النفسي، والأسري: فيقول عن زوجته أَهُّ صَالِحِح -

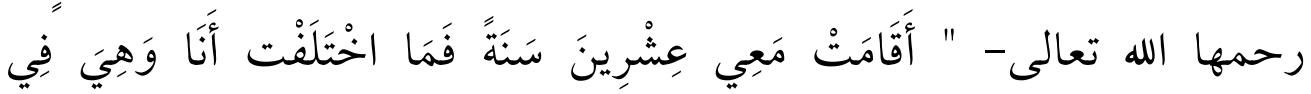

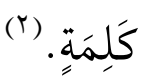

ولذلك حدد الله هذا هذا القانون لعبادة منذ أنزل الأبوين إلي الأرض، وهو أن الاستقرار والأمن لمن اطاع أمره عزوجل واتبع هداه، و الخوف

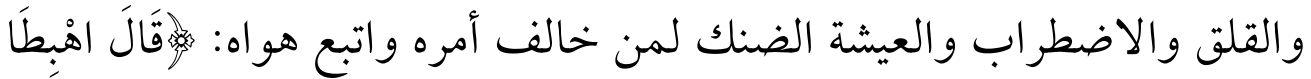

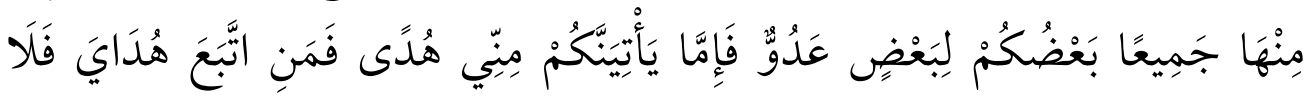

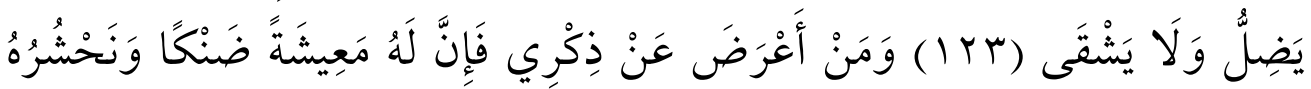

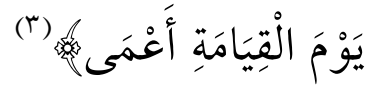

(1) تنظيم الإسلام للمجتمع الشيخ /محمد أبو زهرة ص اله 9 اباختصار.

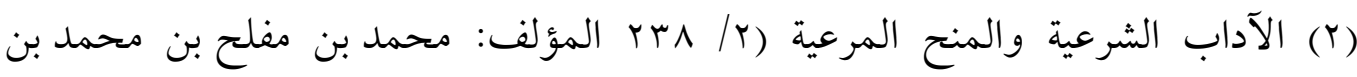
مفرج، أبو عبد الله، شمس الدين المقدسي الرامينى ثم الصالحي الحنبلي (المتوفى:

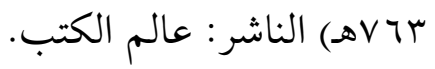

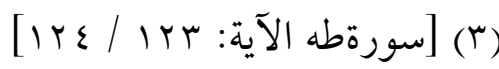




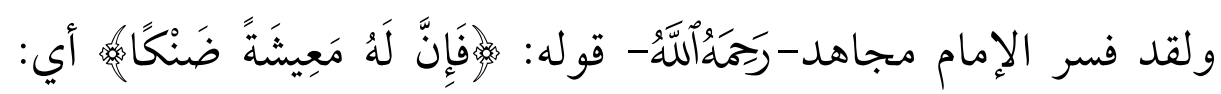

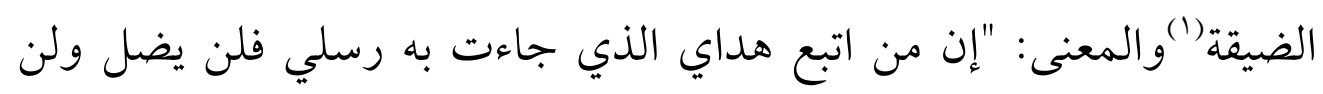

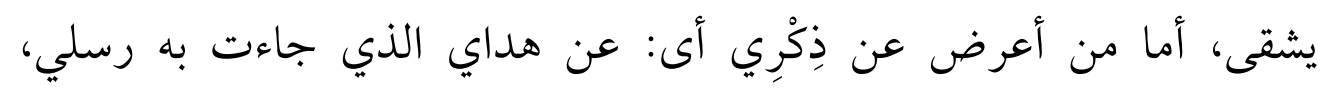

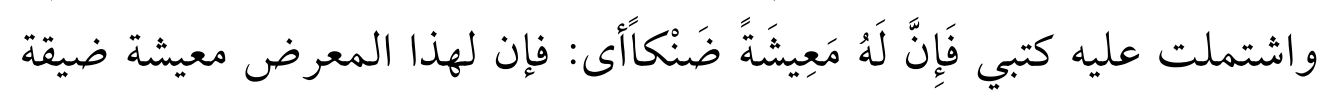

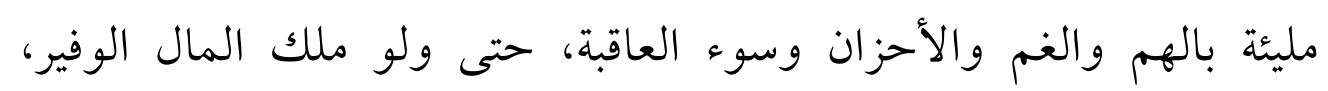

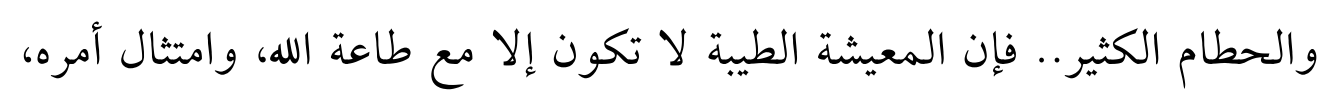
واجتناب نهيه" والنطين

فالذي"يأخذ بهوى نفسه وبمنهج البشر فإن له معيشة ضنكا ضيقة

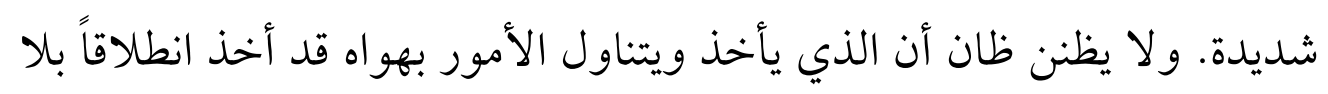

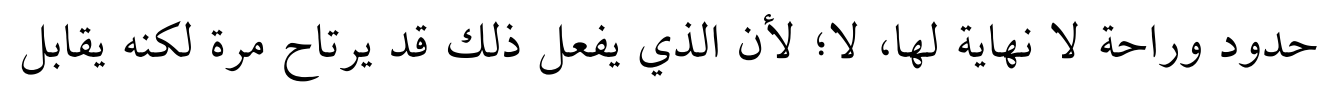

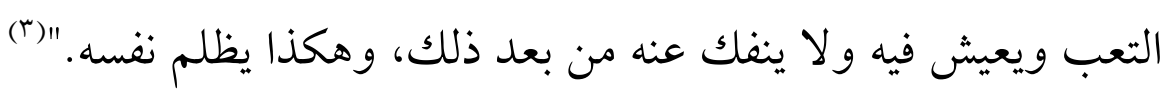

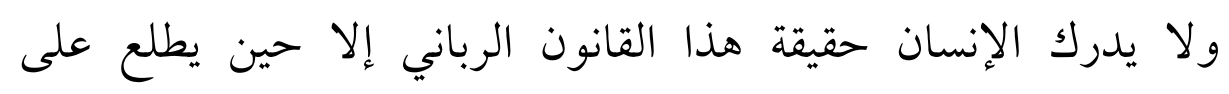

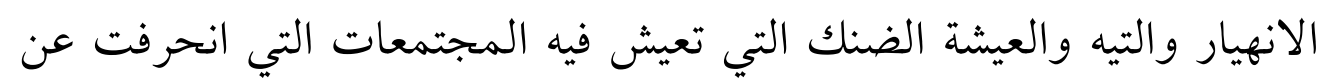

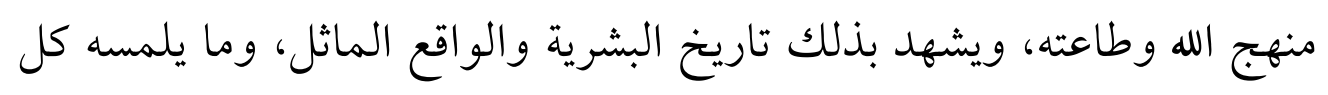

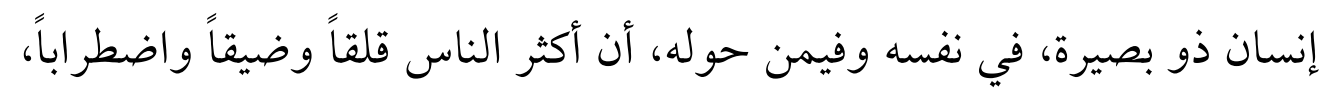

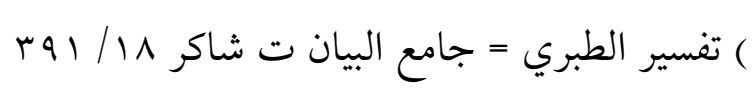

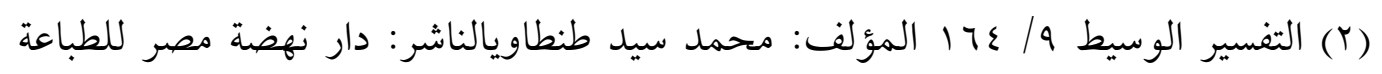

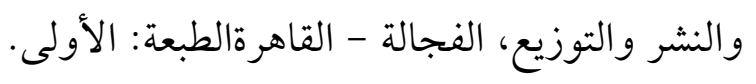

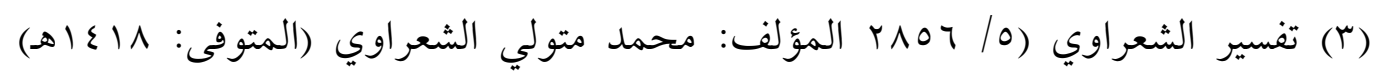

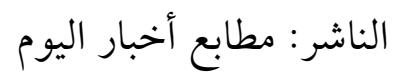
نشر عام 199V م) مطابع اخبار 
هم المحرومون من نعمة الإيمان.

وهذا نموذج عرضه القرآن الكريم لمن إنحرف عن منهج الله، إنها

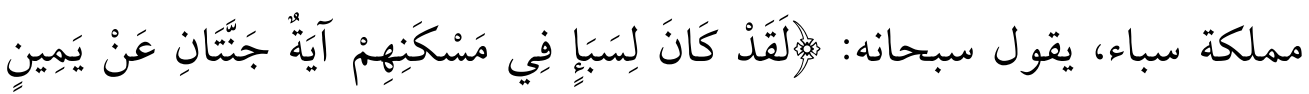

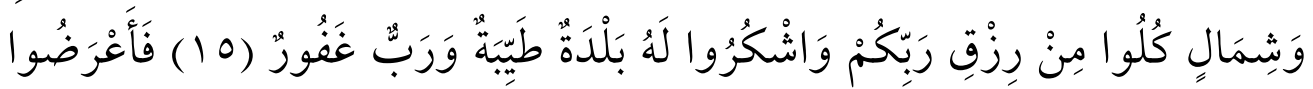

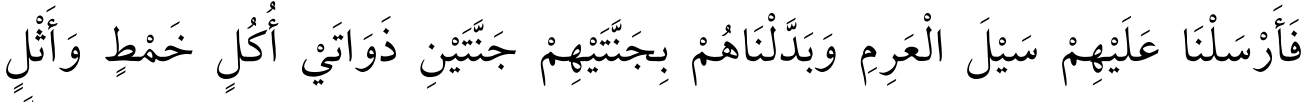

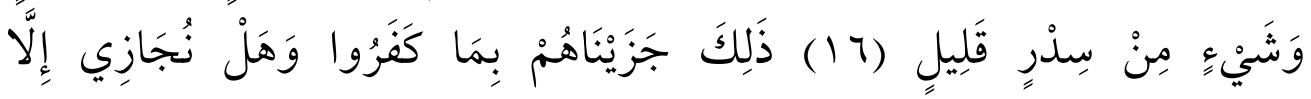

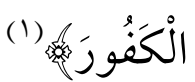

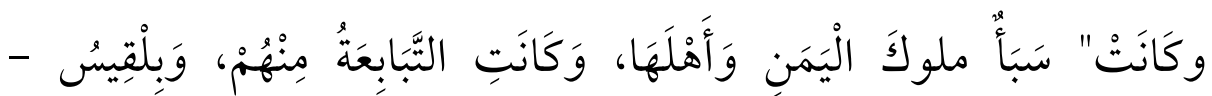

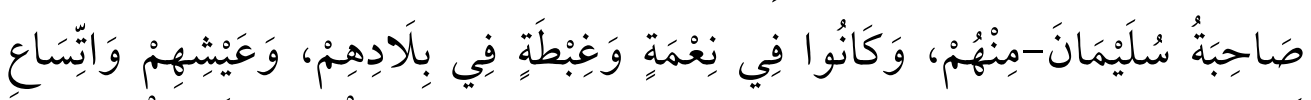

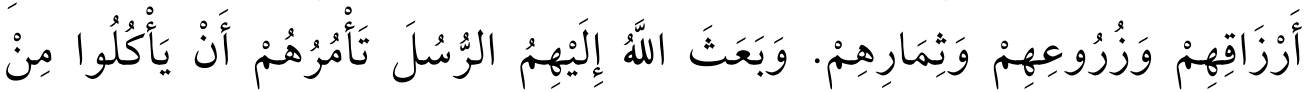

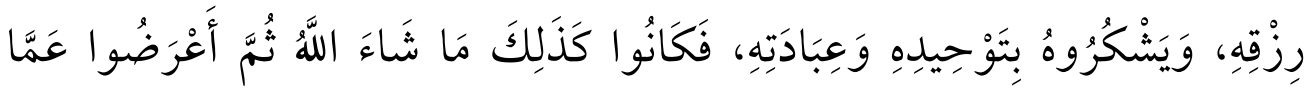

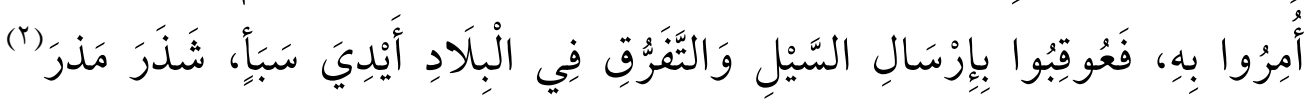

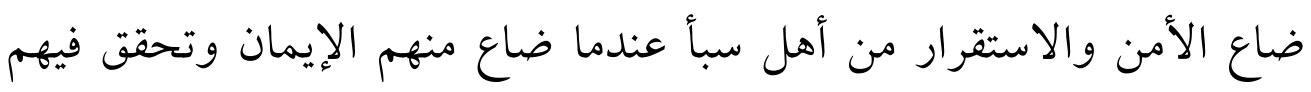

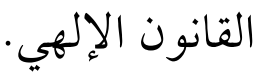

وفي الواقع المعاصر نجد دولة مثل: دولة السويد حيث الحياة والمعيشة فيها شيء لا يتصوره العقل، وتصرف الدولة لكل واحد منهم مبالغ،

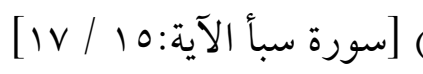

(r) تفسير ابن كثير ت سلامة ج/ / ع.0 المؤلف: أبو الفداء إسماعيل بن عمر بن كثير القرشي البصري ثم الدمشقي (المتوفى: عVVهـ) المحقق: سامي بن محمد سلامةالناشر:

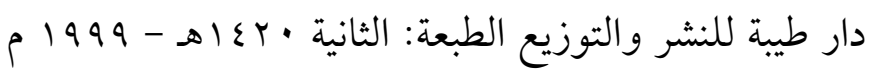


وضماناً صحياً واجتماعياً، ومع هذا هم في أسوا حياة يعيشونها،: فلا ينامون إلا بفعل الحبوب والمخدرات، وتتصدر السويد رأس القائمة في (إحصائية

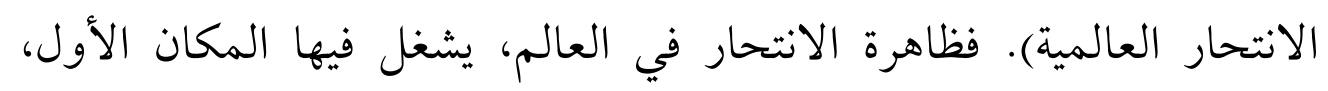

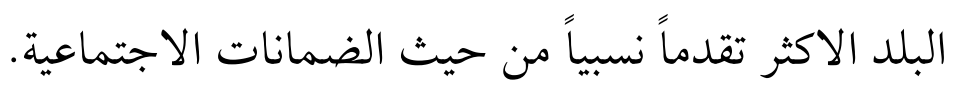

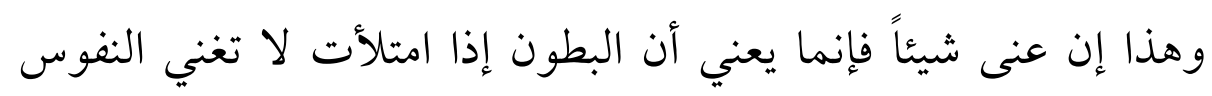

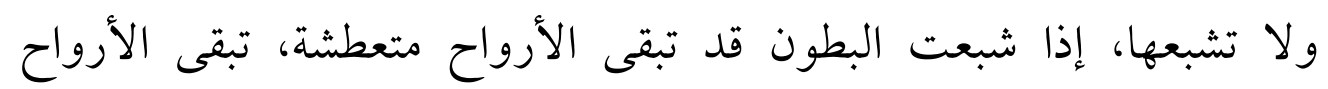

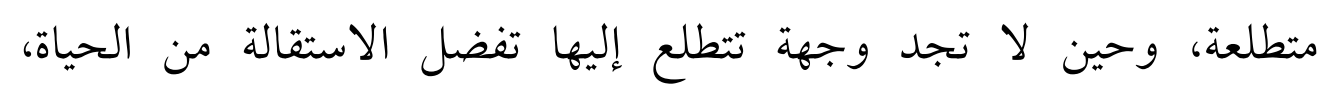

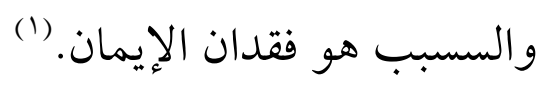

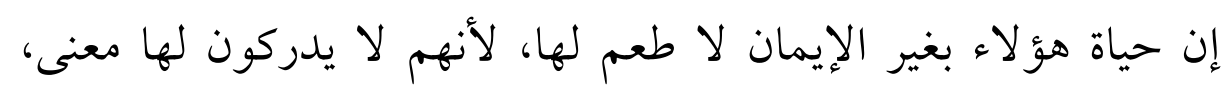

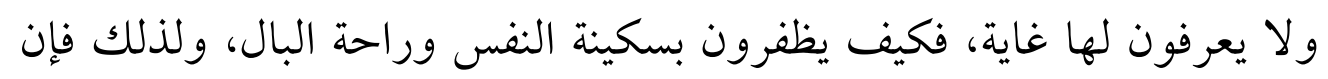

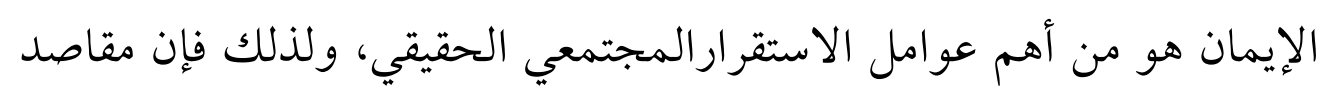
الشريعة تعمل على تحقيقه.

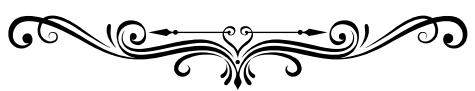

(1) دور المسلم ورسالته في الثلث الأخير من القرن العشرين (ص: r r ب) بتصرف المؤلف:

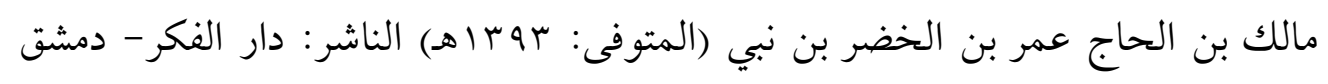

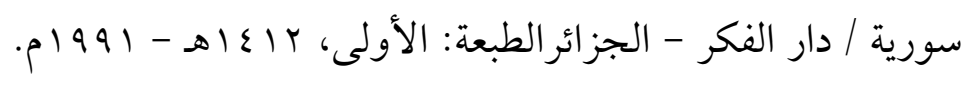




\section{المطلب الثاني}

\section{تحقيق الأخوة والتزابط.}

الأخوة والترابط والاعتصام من عوامل الاستقرار الحقيقي، لذلك قررتها الشريعة، وحققتهاواقعاً عملياً بين المؤمنين بها والمنتسبين إليها.

بل جعلت الشريعة الأخوة مقصداً من مقاصدها فكانت الوحدة بكل صورها، حيث جمعت قلوب اتباعها على الإيمان بالله، وملائكته، وكتبه، ورسله، واليوم الآخر، وجمعت قلوبهم كذلك علي الشعائره التعبدية من صلاة وصيام وزكاة وحج، وجمعتها على قبلة واحدة، وجمعتها على فضائل الأخلاق، و جمعتها على المنهج الذي وضعه الله تعالى لهم لتنتظم حياتهم،

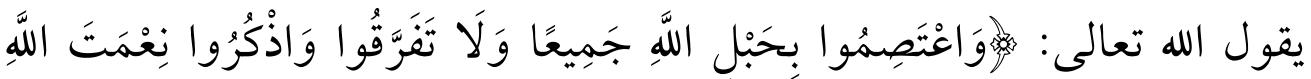

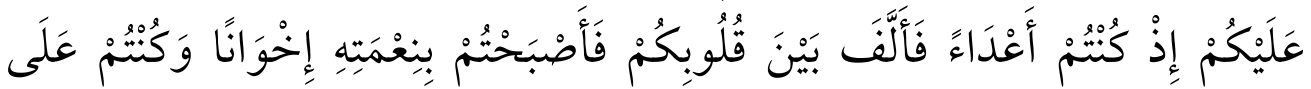

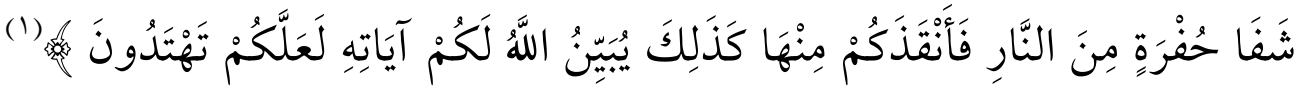
والأخوة في الشريعة الغراء تشمل كل فئات المجتمع، فليس هناك فئة من الناس أعلى من أن تؤاخي الآخرين، ولا فئة أهون من أن يؤاخيها الآخرون، لا يجوز أن يكون المال أو المنصب أو النسب، فالحاكم أخو أح

$$
\text { المحكوم، والراعي أخو لرعيته. }
$$

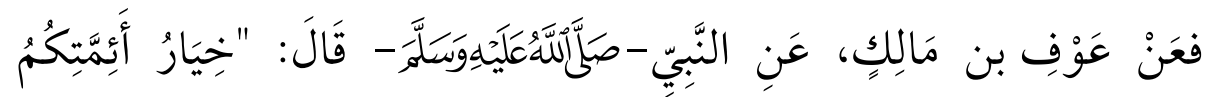

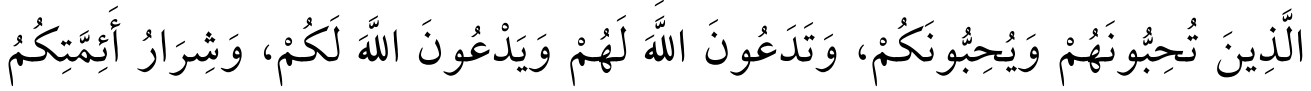

$$
\text { [سورة آل عمران الآية: بـ1) }
$$




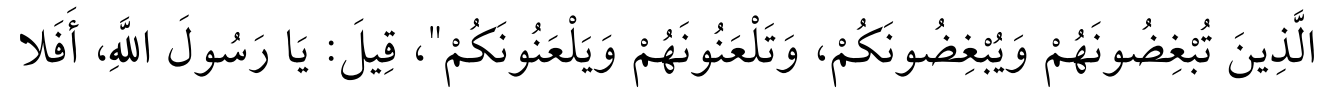

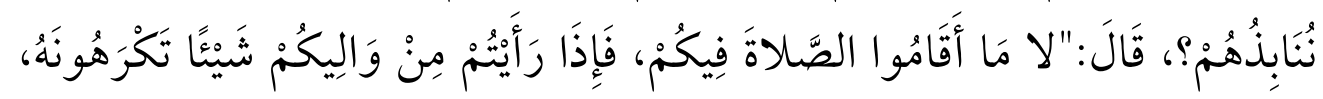

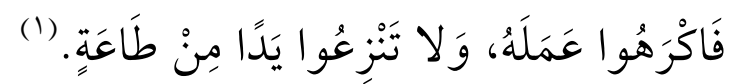

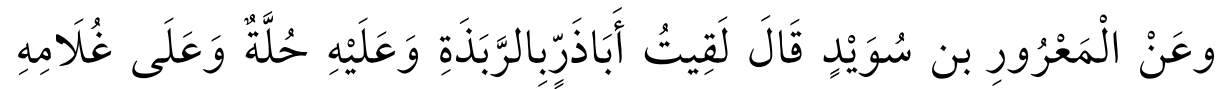

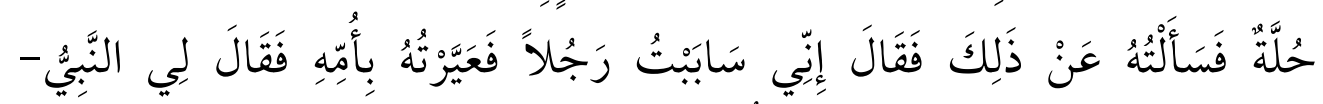

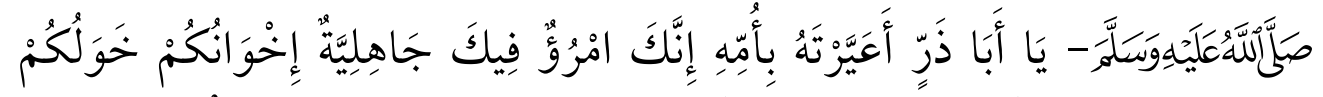

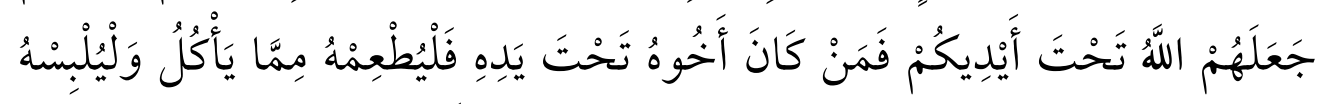

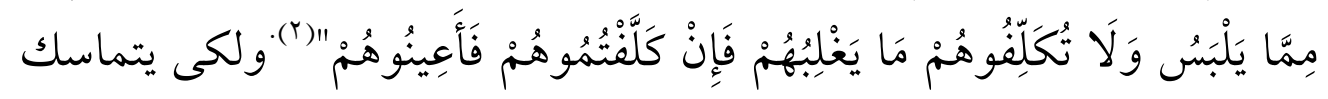

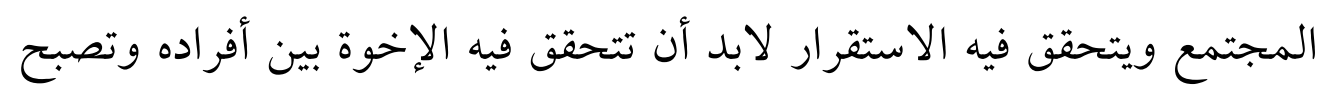

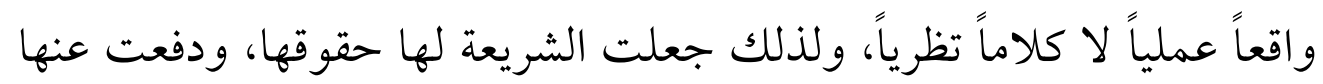
مكدر اتها.

$$
\text { أ- من حقوق الإخوة. }
$$

الحياة المستقرة لا تكون في الأمة إلا إذا أدي كل واحد واجبه نحو

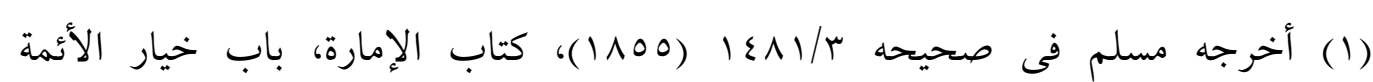

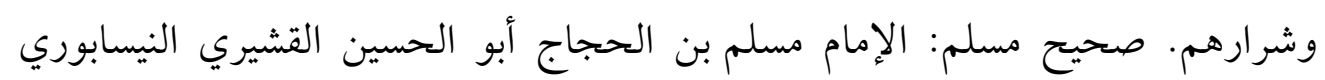

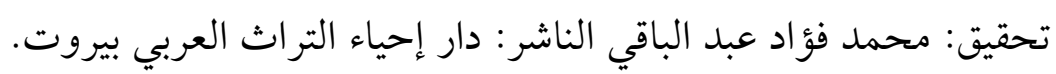

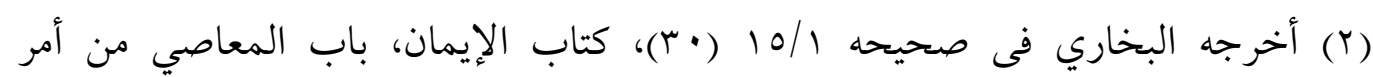

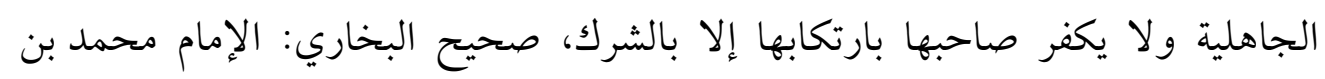

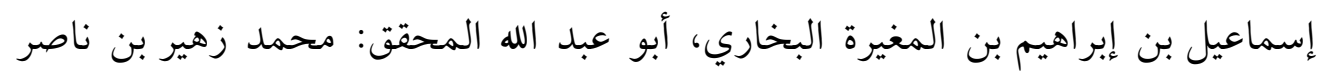

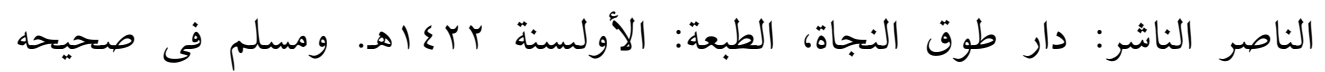

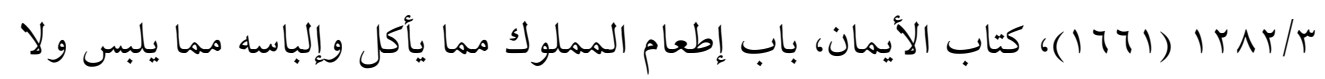

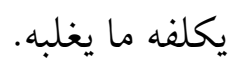


أخية والمجتمع الذي يعيش فيه والإمة التي ينتسب إليها والإنسانية التي هو جزء منها.") ولذلك كانت الحقوق والواجبات و التي حددتها الشريعة الغراء ليتحقق بها الاستقرار والتي منها:

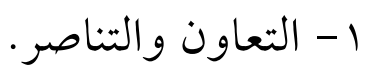

إذاً ما قيمة الأخوة إذا لم تعاون أخاك عند الحاجة، وتنصره عند الشدة،

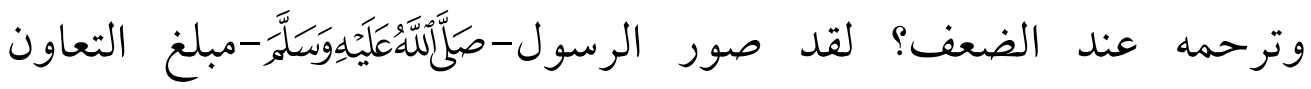
والترابط بين أبناء المجتمع المسلم بعضه وبعض هذا التصوير المعبر حين

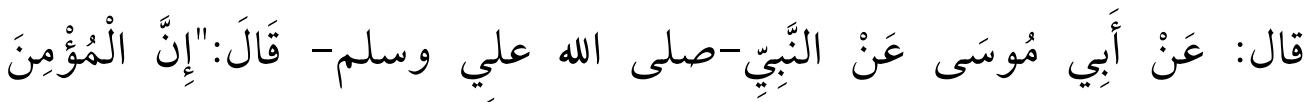

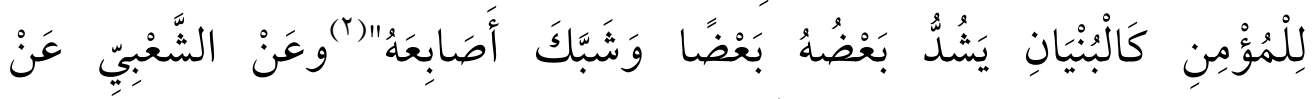

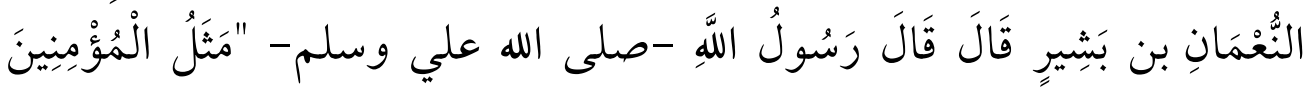

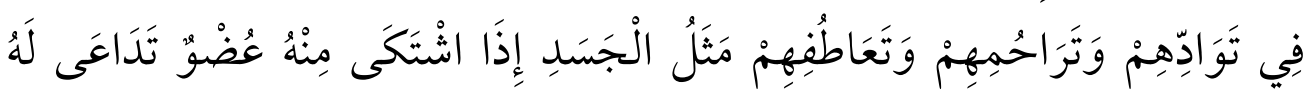

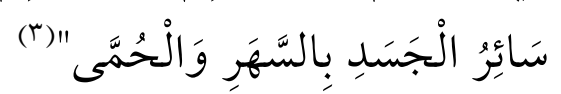

ץ- أداء الحقوق الستة: فعَنْ أَبِي هُرَيْرَةَ أَنَّ رَسُولَ اللَّهِ-صلى الله علي وسلم -

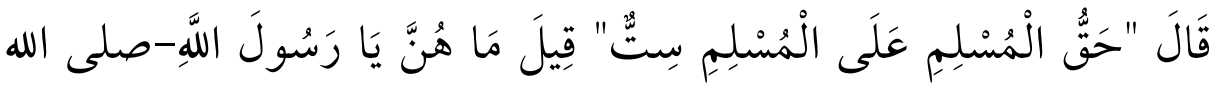

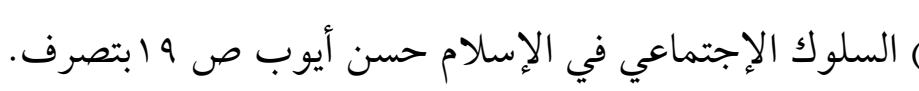

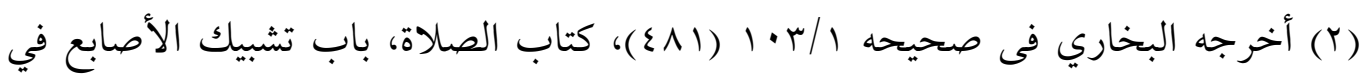

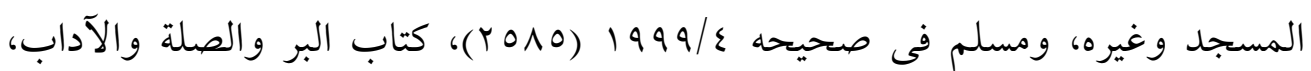

$$
\text { باب تراحم المؤمنين وتعاطفهم وتعاضدهم ومسيم. }
$$

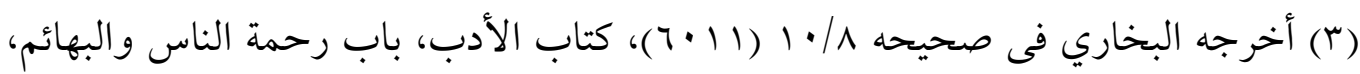

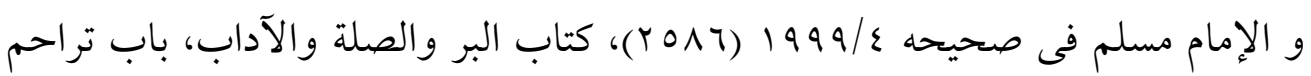
المؤمنين وتعاطفهم وتعاضدهم. 


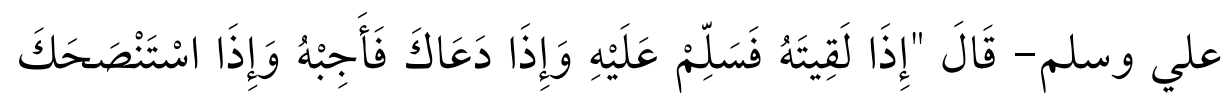

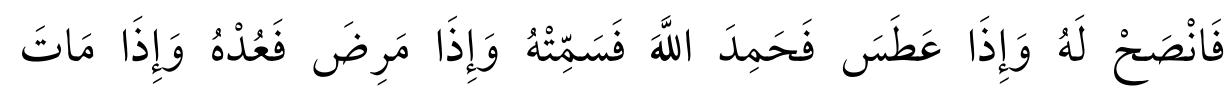

(1)" فَاتَبِْعْدُ

r- اجتناب التباغض وسوء الظن.

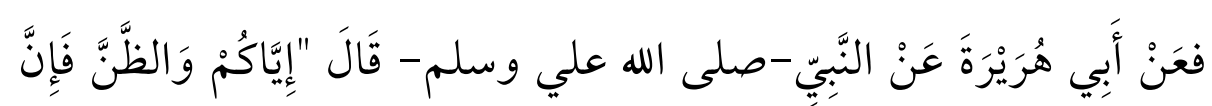

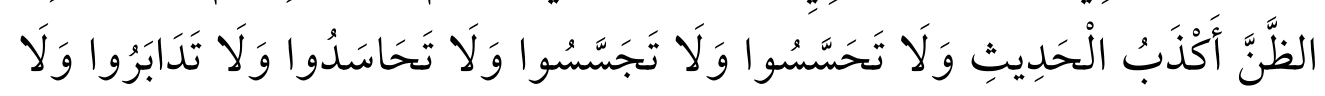

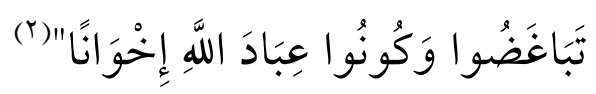

يدلنا هذا الحديث على أن العناصر الأساسية لهذه الأخوة: المحبة،

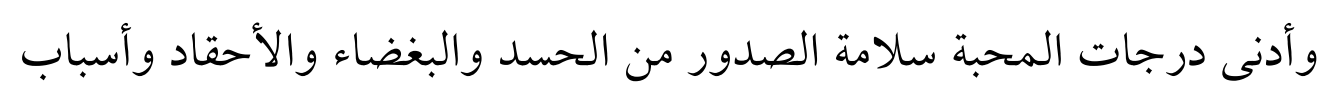
العداوة والشحناء لإن جو البغضاء والشحناء جو عفن كريه. ع - الإعانه والمواساه.

إن من لوازم الأخوة التكافل والتعاون وهذا الذي أكدته الشريعة الغراء،

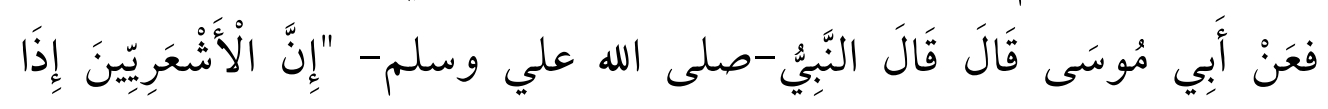

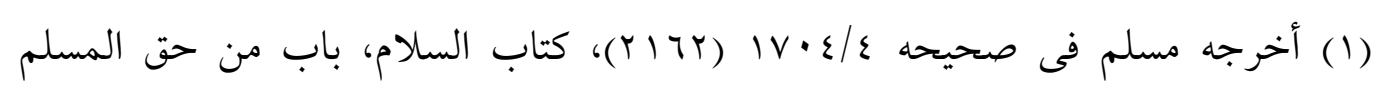

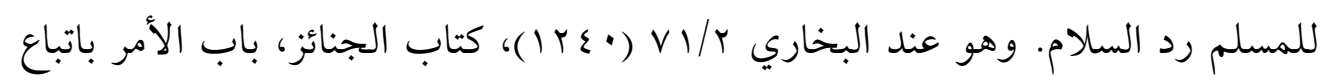

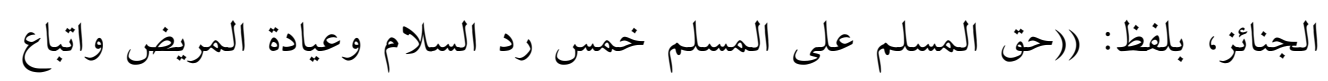

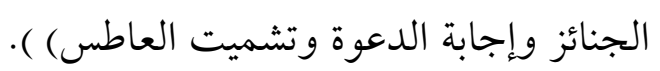

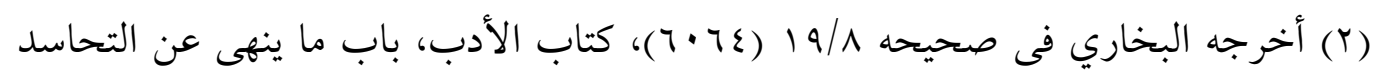

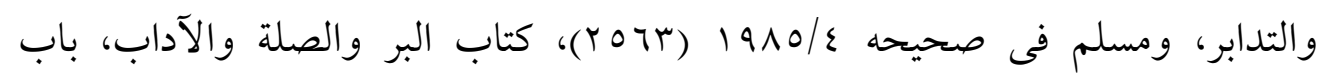
تحريم الظن والتجسس والتنافس والتناجش ونحوها واهيا. 


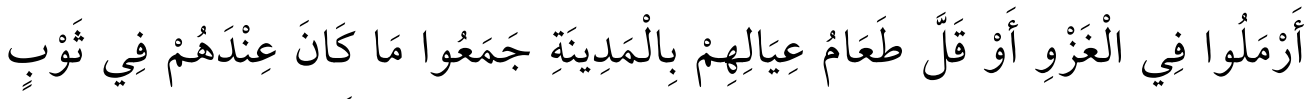

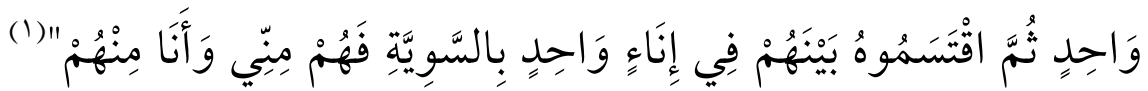

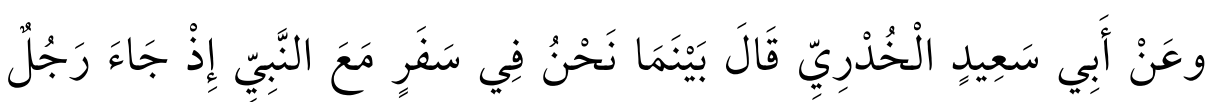

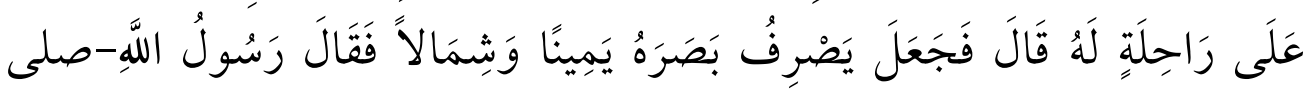

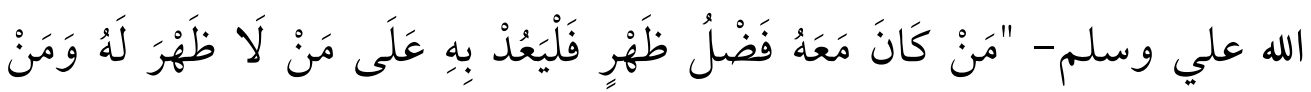

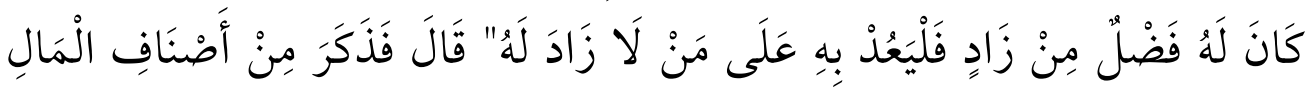

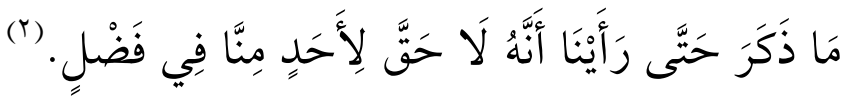

$$
\begin{aligned}
& \text { 0- السعي في حاجته. }
\end{aligned}
$$

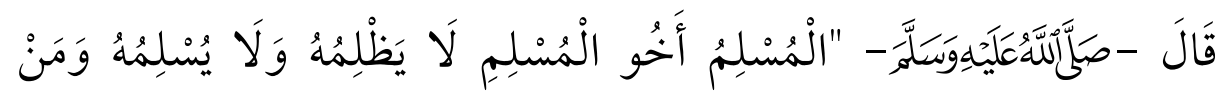

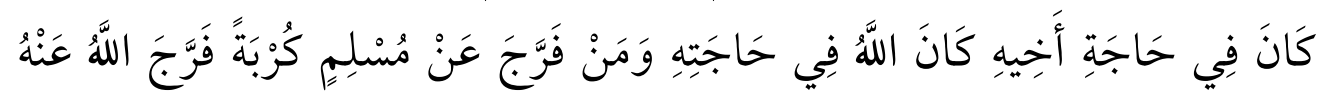

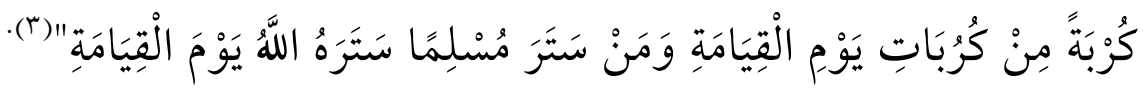

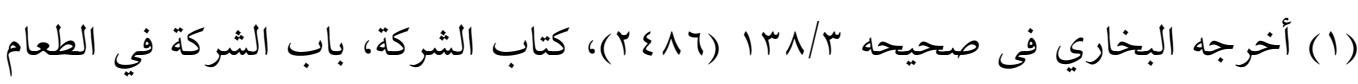

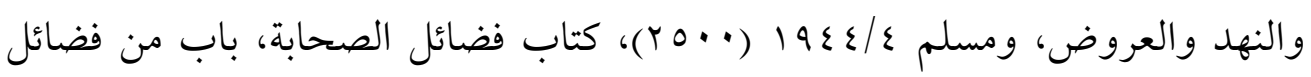

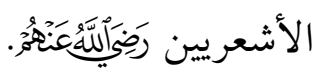

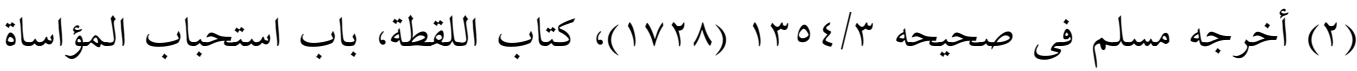
بفضول المال.

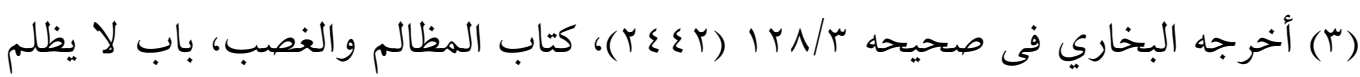

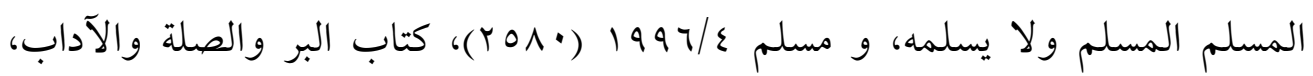

$$
\text { باب تحريم الظلم. }
$$


7- النفقة وبذل الطعام والإثار.

فعنْ ثَوْبَانَ قَالَ قَالَ رَسُولُ اللَّهِ-صلى الله علي وسلم - "أَفََْلُ دِينَارِ يُنْفِقُهُ

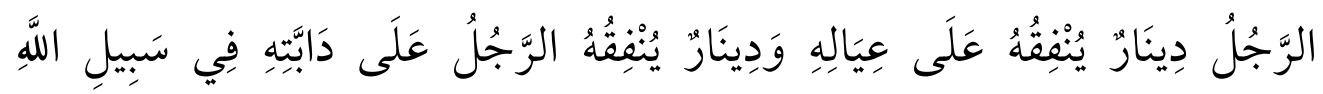

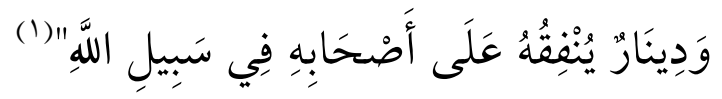

الصحابة يعلموننا الإيثار، كما جاء فى الحديث عَنِ الثَِِّْْيّ، عَنْ حُمَيْدٍ

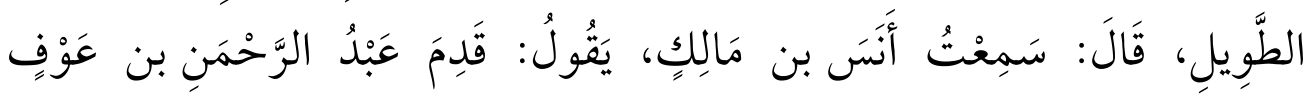

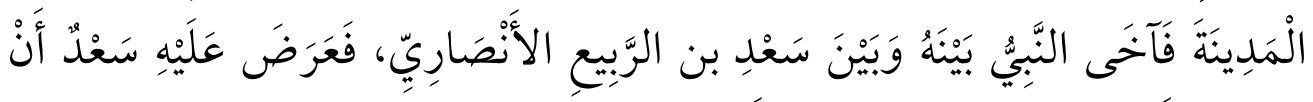

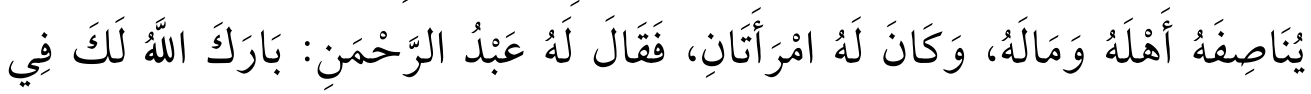

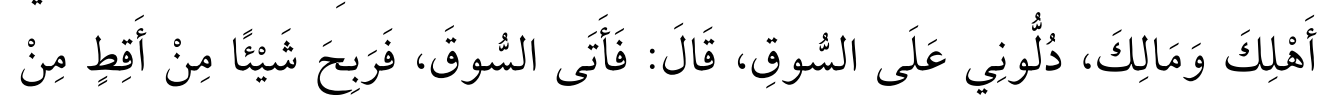

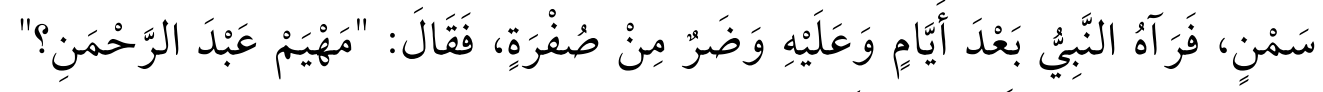

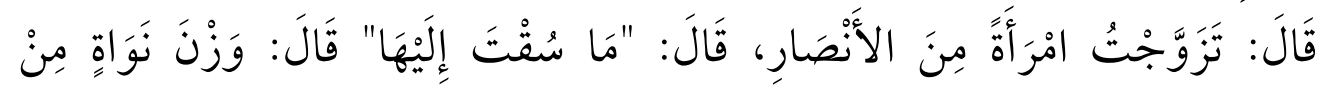

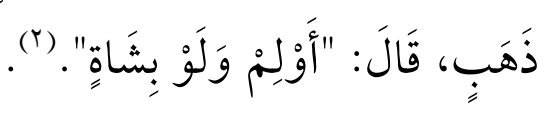

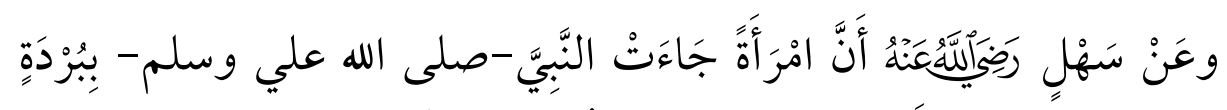

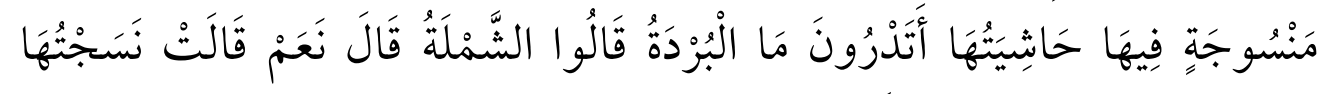

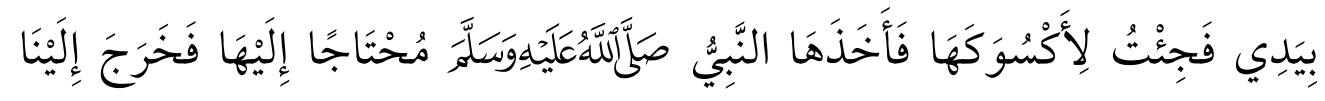
(1) أخرجه مسلم فى صحيحه /1/79 ( (999)، كتاب الزكاة، باب فضل النفقة على العيال

$$
\text { والمملوك و إثم من ضيعهم أو حبس نفقتهم عنهم. }
$$

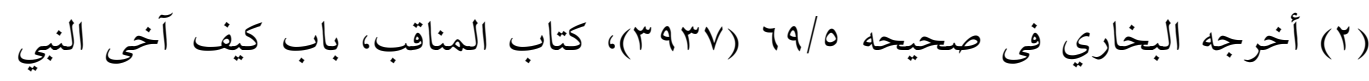

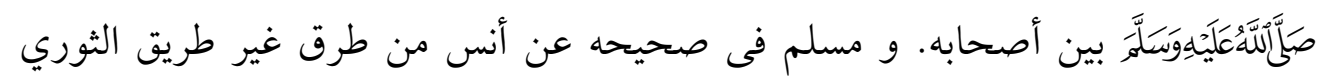

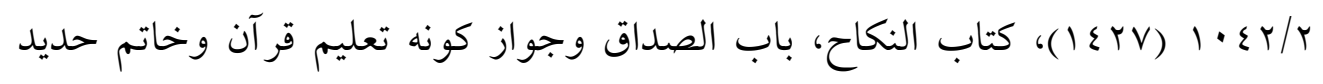

$$
\text { وغير ذلك. }
$$




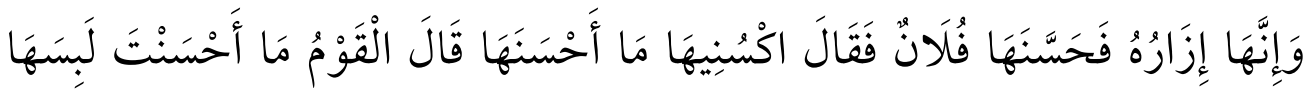

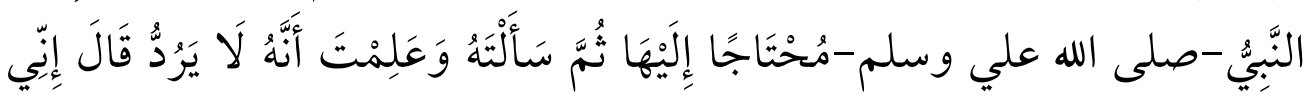

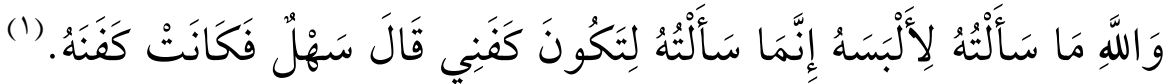
و "بالإيثار ترتقى شخصية المسلم الإيمانية ويستشعر عظمة الإسلام فى تصى كل كيانه وهى تمده بقوة روحية عالية فيرى الوجود من حوله كأنه أسرة واحدة يظلها الدين بسماحته ويسره فلا عسر ولاحرج بعطاءه وسخاءه فلا

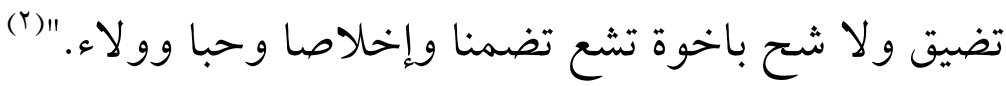
ب- من مكدرات ومعوقات الأخوة:

للحفاظ علي الأخوة بين المؤمنين أغلقت الشريعة ودفعت كل باب يعكر صفوها لأن بتعكير صفوها يتعكر صفو الاستقرار ومن ذلك: لانكين

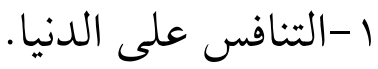

التنافس على الدنيا من شأنه أن يولد الغيرة، وبالتالي الحسد وإيغار

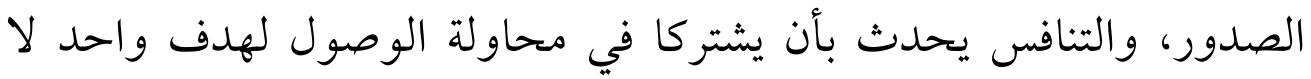

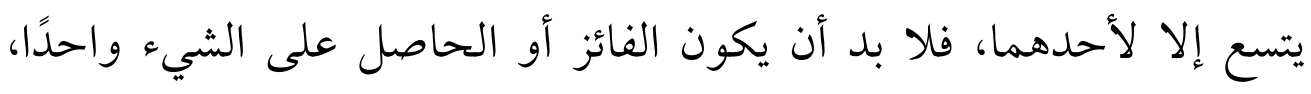
فيحصل بينهما تنافس عليه مما يوغر الصدور، ويفسد الأخوة ويكدرها. r- الجدال والمراء: فالجدال والمراء يوحشان القلوب، ويوغرانها لا سيما

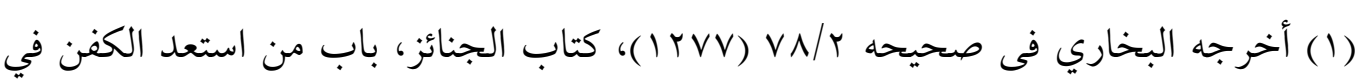

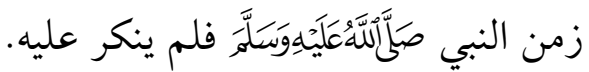

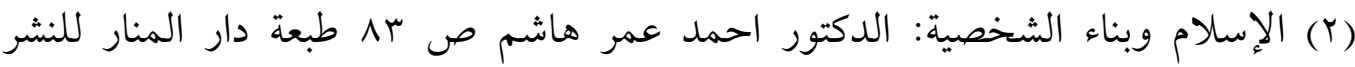

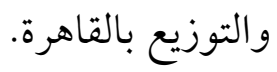




\section{إذا أصبحا لحظ النفس لا لإظهار الحق.}

r- التفاخر بالأنساب: وهذا لا شك أنه من عمل الجاهلية، وهذا إن كان

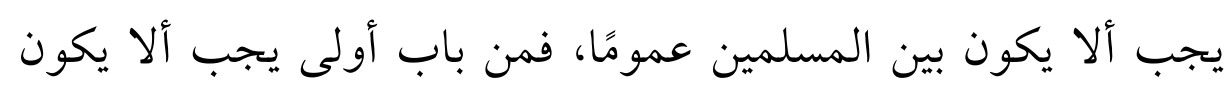

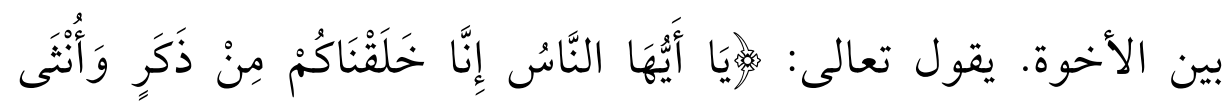

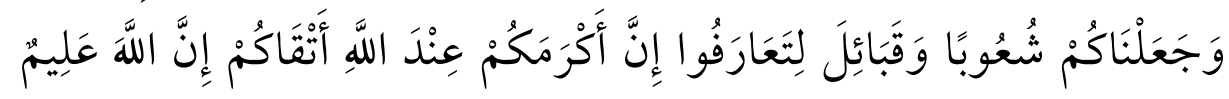

$$
\text { (1) خَبِيرِ }
$$

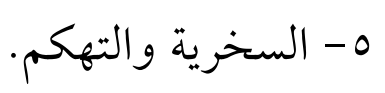

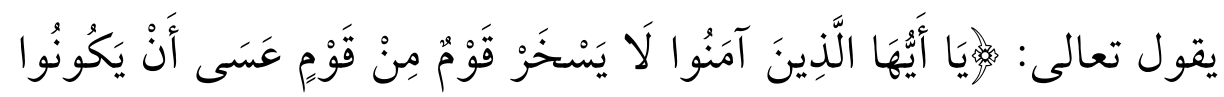

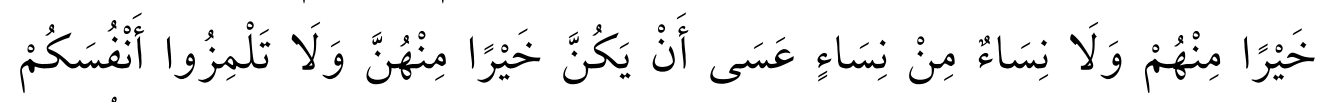

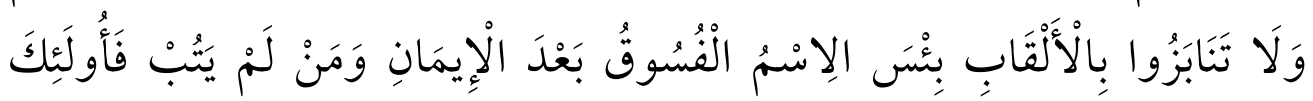

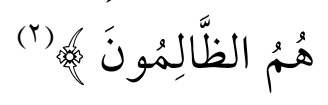

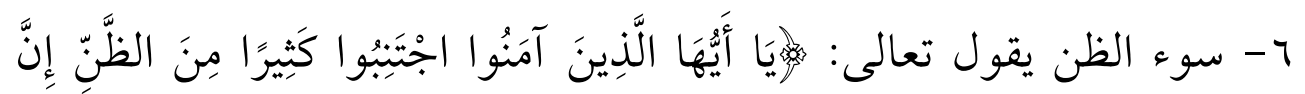

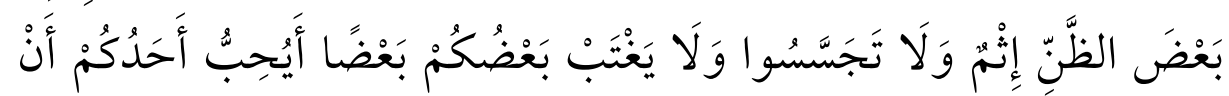

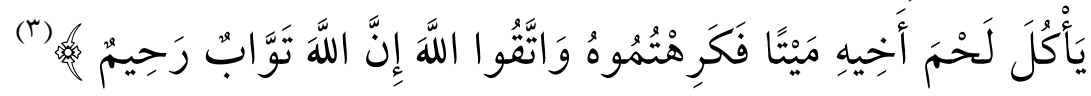

وكل هذه المكدرات وغيرها لاشك تثير الفرقة والاختلاف والله حذرنا

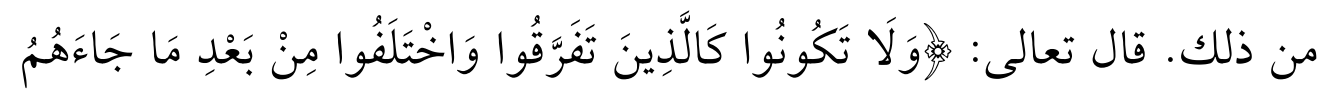

$$
\begin{aligned}
& \text { (1) [سورة الحجرات الآية: با، ع1) }
\end{aligned}
$$

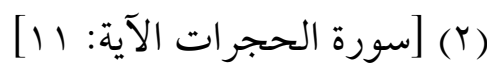

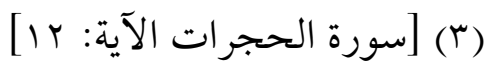




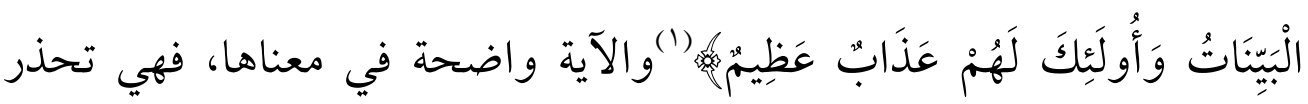
من التفرق وتدعو إلى الوحدة وجمع الكلمة.

وخلاصة القول: إن قياس تحقق الاستقرار في أي مجتمع هو بمدي

تماسك فئات هذا المجتمع وترابطه، وجملة هذه الأداب السابقة وغيرها الكثيرتعد هي المؤسس الأول لتحقيق التماسك والترابط، وهذه التعاليم تجسدت في واقع الأمة وعاشها أصحابها معايشة عملية، وعما بها الخير ووجد الناس آثارها وشهد العدو قبل الصديق بها، فكانت الأمة جسداً واحداً وقلباً واحداً، فعم بهذا الإخاء الاستقرار والأمن، وإن أكثر ما يهدد الاستقرارالمجتمعي هو: الفرقة والتنازع والانقسام والتناحر، حيث إن وقوع ذلك يترتب عليه حصول الازمات التي تؤدي الى ضياع الاستقرار في المجتمع، والواقع خير شاهد على ذلك حيث المجتمعات المتناحرة في واقعنا المعاصر غير مستقرة. 


\section{المطلب الثالث}

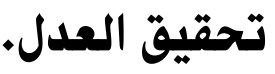

من مقومات الاستقرار تحقيق العدل بين أفراد المجتمع بغض النظر

$$
\text { إلي الدين أو الون أو الجنس. }
$$

والمراد بالعدل أن يعطى كل ذي حق حقه، فلا يبخس حقه ولا يجور على حق غيره، و العدل هو أساس العمران وسبب الاستقرار، ولذلك جاء" الإسلام فكان دين الحق والعدل في كل شيء، مع النفس والأهل والقرابة، وجميع الناس حتى الأعداء، والعدل قائم على الخشية من الله، وتقوى الله في السّر والعلن، والإيمان منبع كل فضيلة"(1) وقد ألزم الإسالم" قادة المسلمين وحكامهم وقضاتهم من مراعاة العدل في المعاملة بين المسلمين، دون تمييز بين عناصرهم وفئاتهم وطبقاتهم

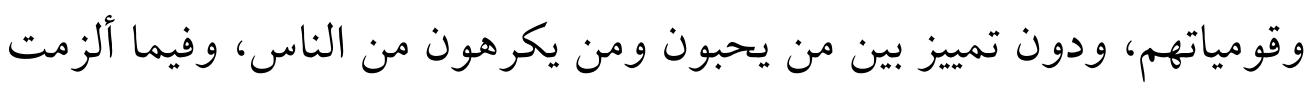
به جميع المسلمين من التقييد بحقوق التسوية ضمن إطار العدل بين عناصر المسلمين وفئاتهم وطبقاتهم وقومياتهم أيضًا، فالمسلمون كل المسلمين سواء أمام الحق، وبين يدي القضاء، وفي تقدير الكفايات، وإيجاد فرص العمل المتكافئة للجميع، وهي اقتباس العلم والمعرفة، لا تمييز بين عنصر منهم وعنصر، ولا بين فئة وفئة، ولا بين طبقة وطبقة، ولا بين قوم وقوم، ولا بين

(1) التفسير الوسيط: صع إع المؤلف: د وهبة بن مصطفى الزحيلي الناشر: دار الفكر -

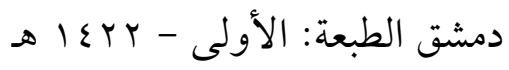


نساء ونساء. (1)

وكم حفل التاريخ بنماذج رائعة، حكم فيها لغير المسلمين، ضد المسلمين، وللرعية ضد الراعى فسعد الجميع واستقر ومن ذلك.

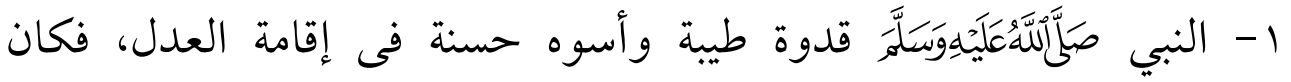

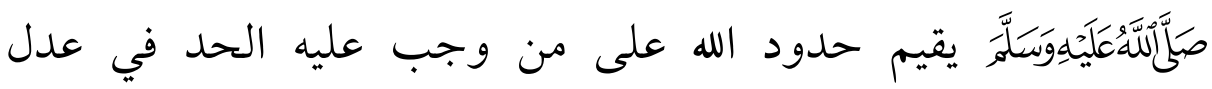
وإنصاف لا تأخذه في ذلك لومة لائم ولا قرابة قريب ولا مكانة شريف.

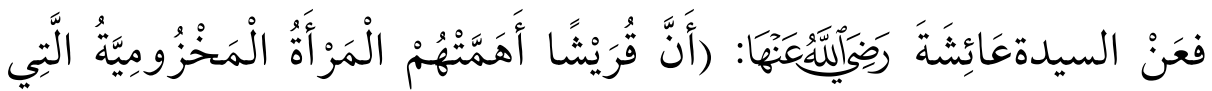

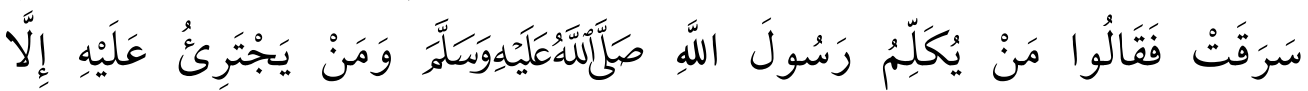

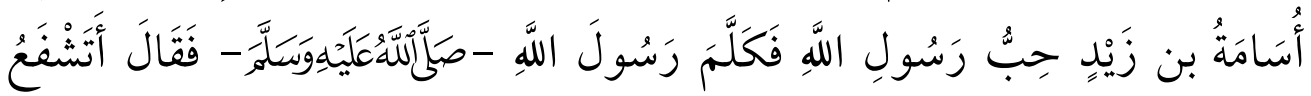

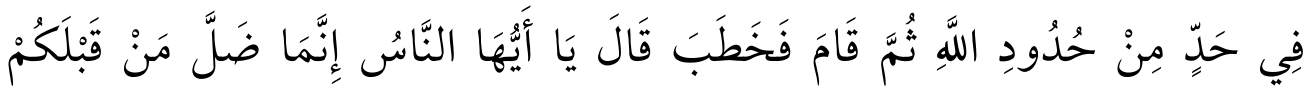

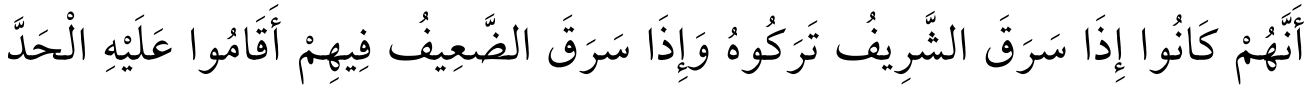

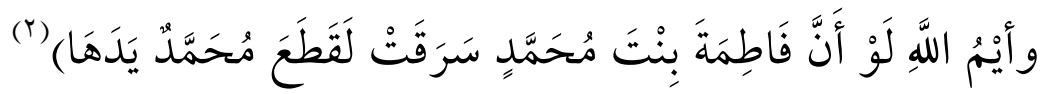
ץ- و"هذا رجل من أهل مصر يشكو ابن عمرو بن العاص الذى ولى على (1) الحضارة الإسلامية أسسها ووسائلها وصور من تطبيقات المسلمين لها ولمحات من

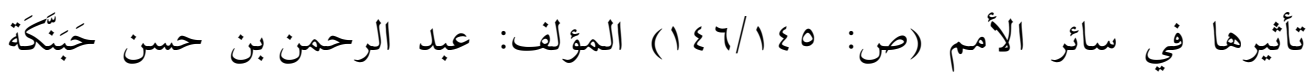

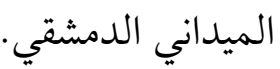

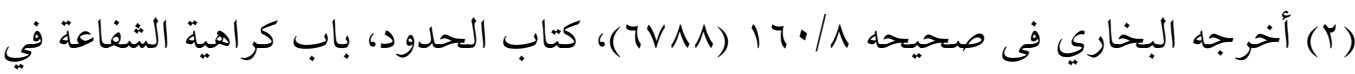

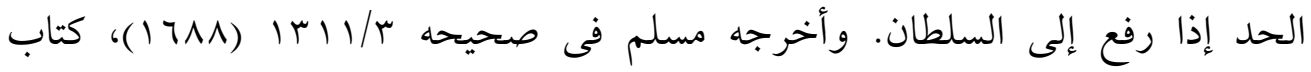
الحدود، باب قطع السارق الشريف وغيره والنهي عن الشفاعة في الحدود. 


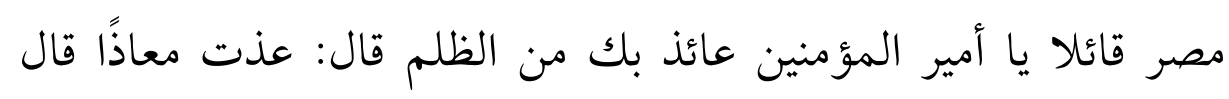

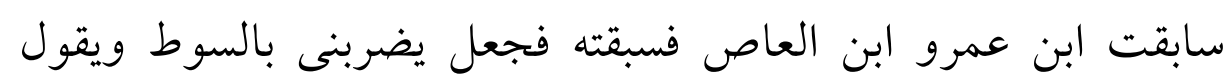

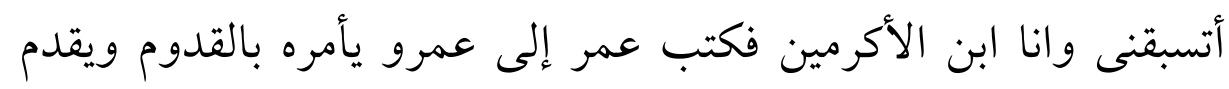

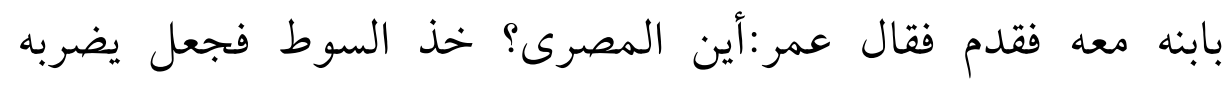

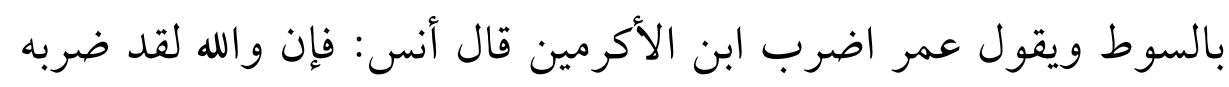

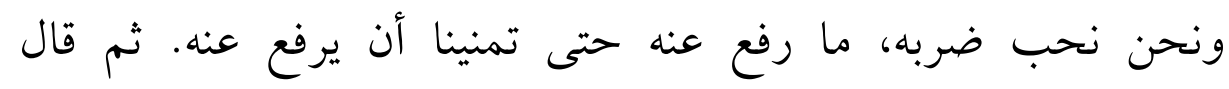

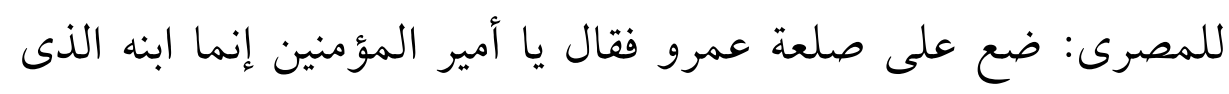

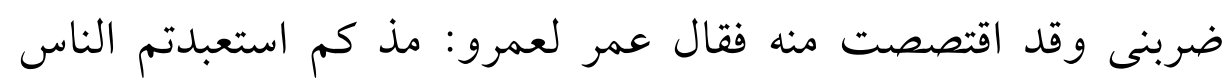

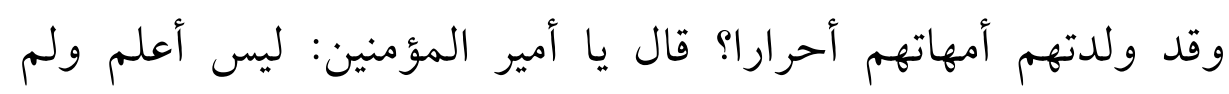

\section{يأتنى. ") وقل ولن}

فالمجتمع الذي يسوده العدل يطمأن ويستقر، أماالمجتمع الذي يسوده

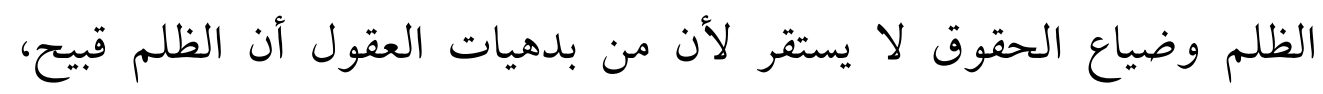

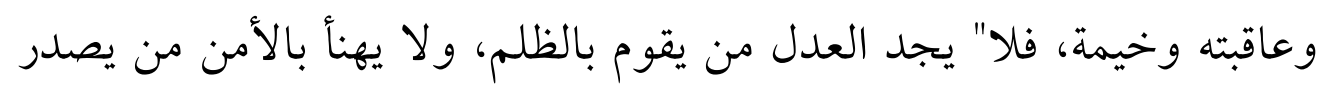

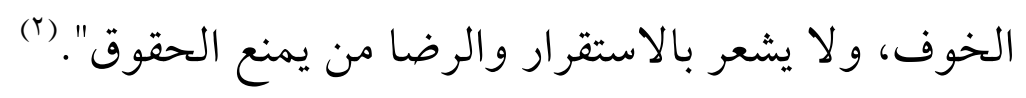

وهذه من سنن الله عزوجل في خلقه أنه يأذن بزوال الإمم الظالمة، حيث يقول سبحانه:

(1) مناقب أمير المؤمنين عمر ابن الخطاب رضى الله عنه صهو للحافظ ابن الجوزى ط

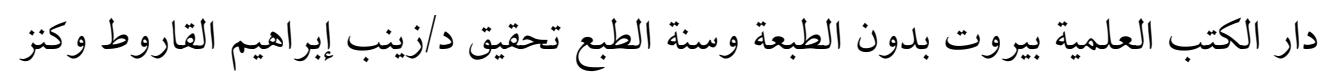

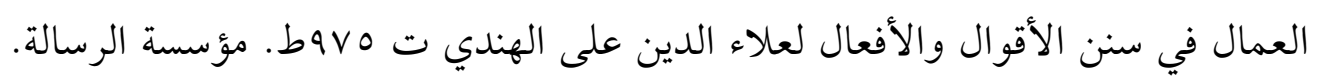
(7r / / T r )

(r) السلوك الإجتماعي في الإسلام حسن أيوب ص 19 


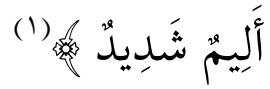

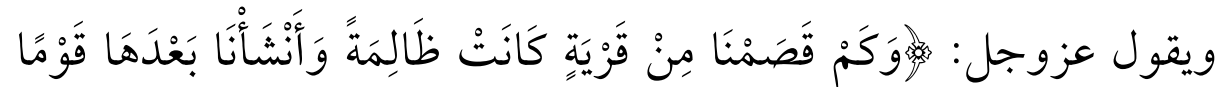

$$
\text { آخَرِينَ وَهِ }
$$

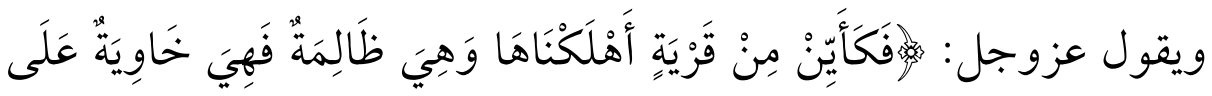

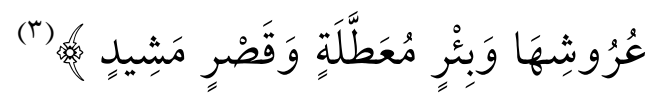

ويقول عزوجل:

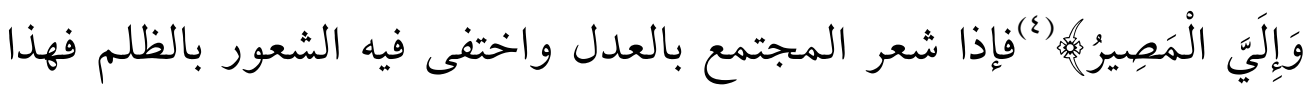
المجتمع سيسوده التعاون والتكافل ويتحقق فيه الاستقرار.

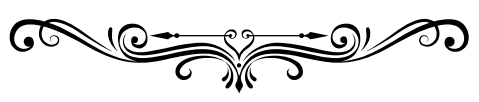

$$
\begin{aligned}
& \text { (1) [سورة هود الآية: ب•1] } \\
& \text { (r) [سورة الأنبياء الآية: 11 11) }
\end{aligned}
$$

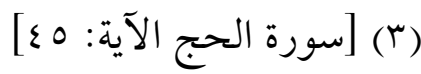

$$
\begin{aligned}
& \text { (ع) [سورة الحج الآية: ^^ع] }
\end{aligned}
$$




\section{المطلب الرابع}

\section{تحقيق التعايش السلمي.}

التعايش السلمي من المقومات الأساسية التي يقوم عليه الاستقرار المجتمعي، لذلك حرصت الشريعة علي نشره وتحقيقه.

وهذا نموذج عملي للتعايش السلمي الحقيقي الذي وحققه الرسول

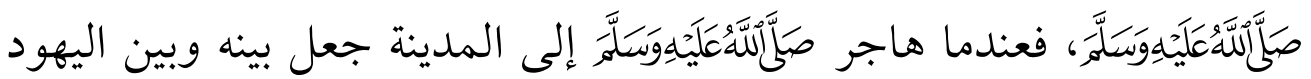

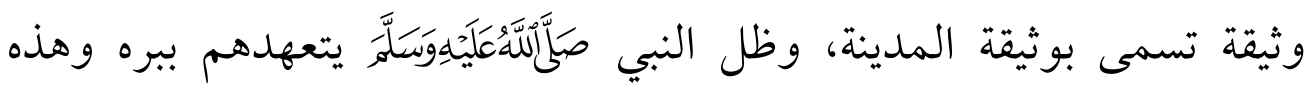

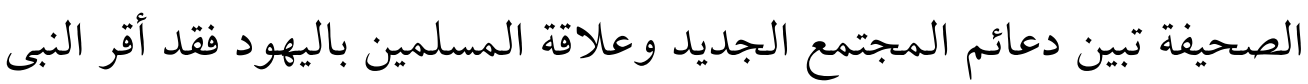

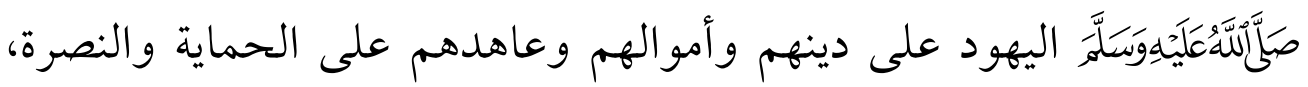
وهذة بعض نصوصها.

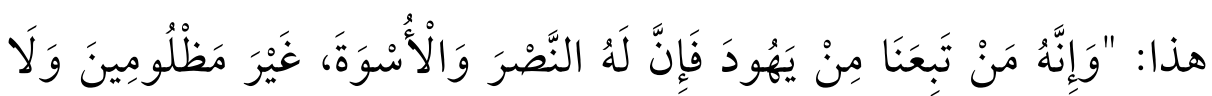

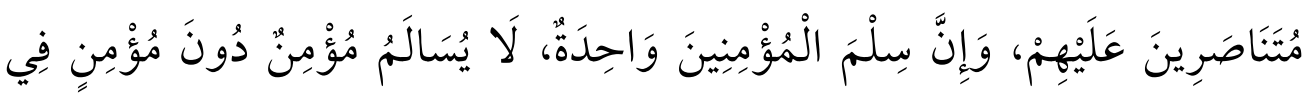

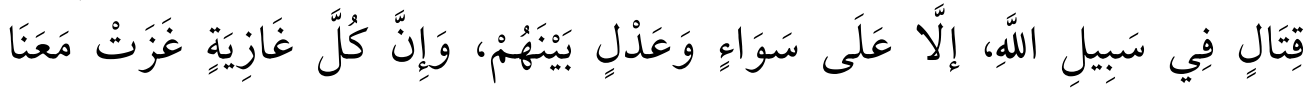

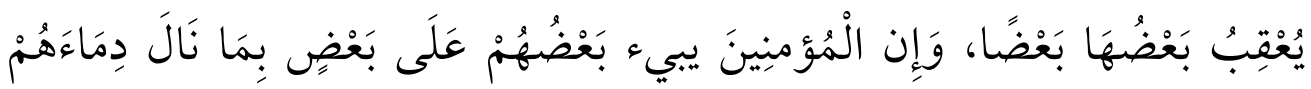

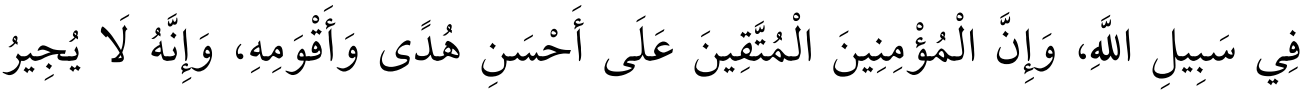

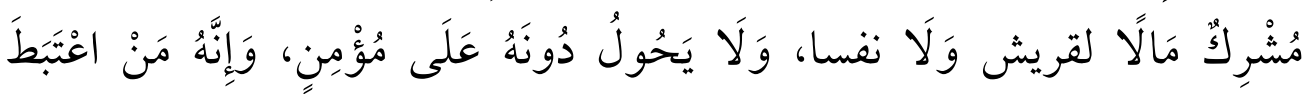

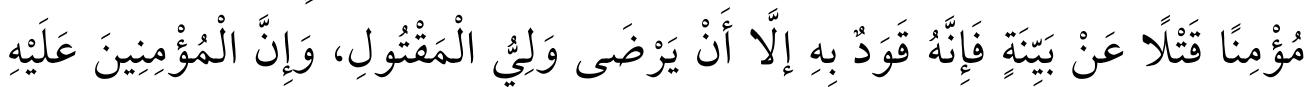

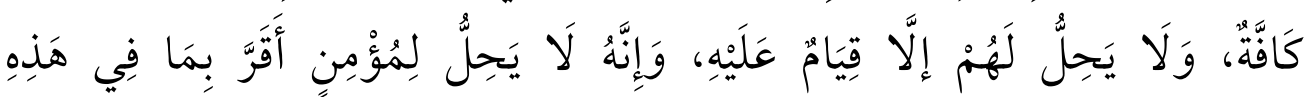

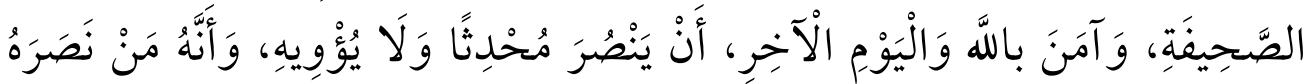




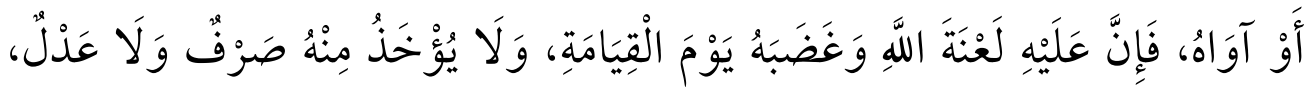

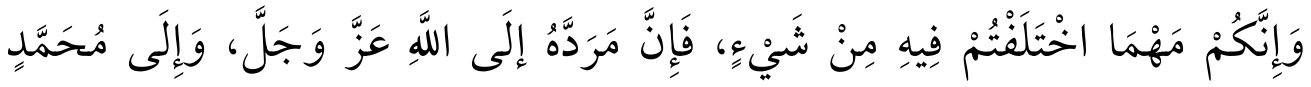

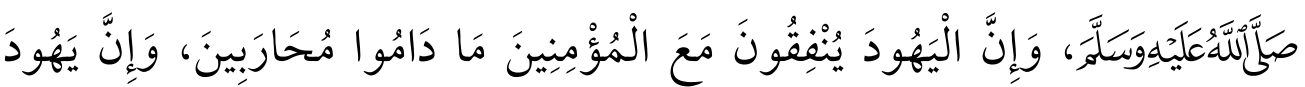

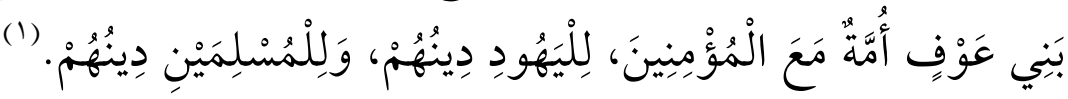
والناظر إلى أصول هذه المعاهدة يجد رغبة المسلمين فى التعاون الخالص مع يهود المدينة لنشر الاستقرار فى ربوعها والضرب على يد كل معتد على حر ماتها ومهدد للاستقرارها.

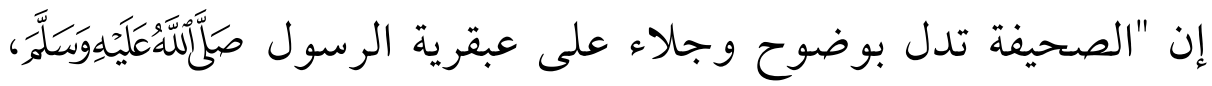
في صياغة مو ادها وتحديد علاقات الأطراف بعضها ببعض، فقد كانت مو ادها مترابطة وشاملة، وتصلح لعلاج الأوضاع في المدينة آنذاك، وفيها من القواعد والمبادئ ما يحقق العدالة المطلقة، والمساواة التامة بين البشر، وأن يتمتع بنو الإنسان على اختلاف ألو انهم ولغاتهم وأديانهم بالحقوق والحريات بأنواعها. ولا تزال المبادئ التي تضمنها الدستور في جملتها معمولاً بها، والأغلب أنها ستظل كذلك في مختلف نظم الحكم المعروفة إلى اليوم... وصل إليها الناس بعد قرون من تقريرها في أول وثيقة سياسية دوَّنها الرسول

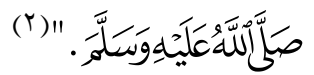

(1) سيرة ابن هشام ت السقا (1/ r •0) المؤلف: عبد الملك بن هشام بن أيوب الحميري

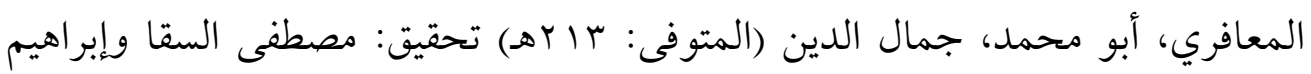
الأبياري وعبد الحفيظ الشلبي الناشر: شركة مكتبة ومطبعة مصطفى البمان البابي الحلبي

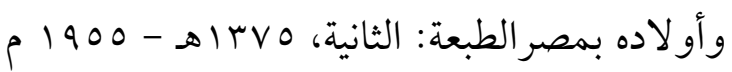
(ז) السيرة النبوية عرض وتحليل: للصلابي جا ص بrاr للدكتور علي محمد الصلابي 
ولذلك نجد الإسلام لم يكره أحدا على اعتناقه، ينقل الأستاذ أنور الجندى عن المستشرق غوستاف لوبون قوله: " ترك المسلمون الناس أحرارا

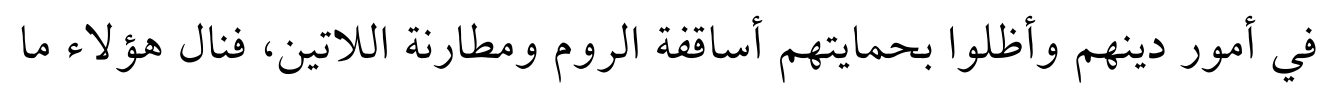

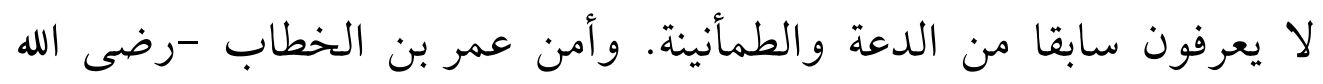

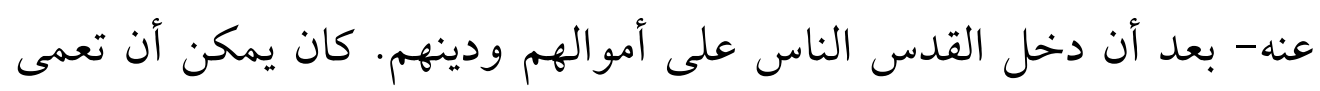

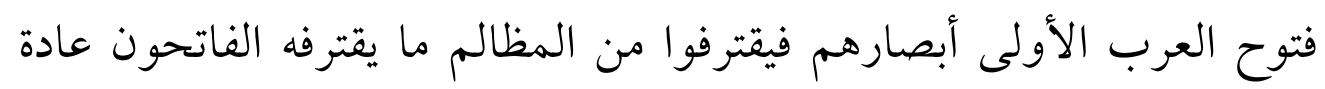

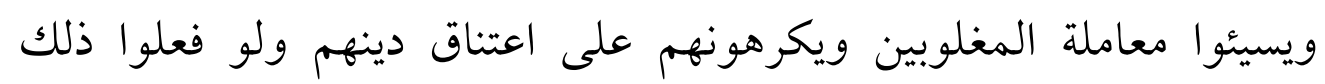

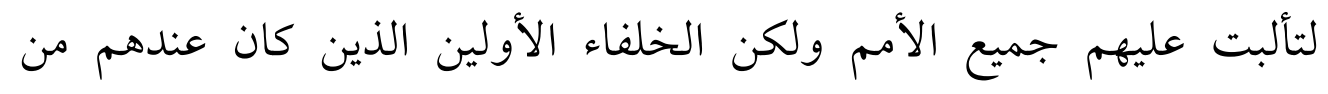
العبقرية ما ندر وجوده في دعاة الديانات الجديدة أدركوا أن النظم والأديان

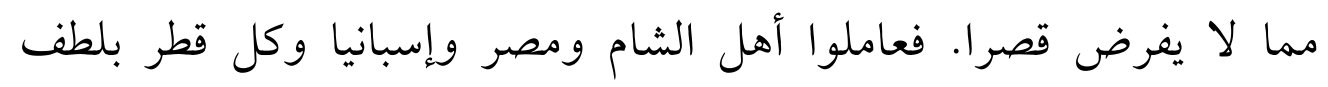

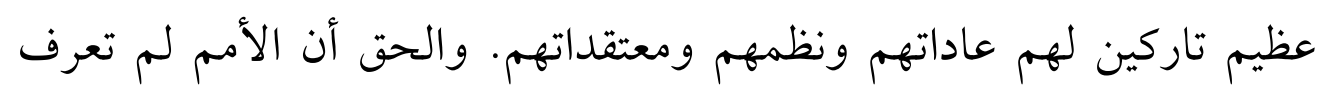

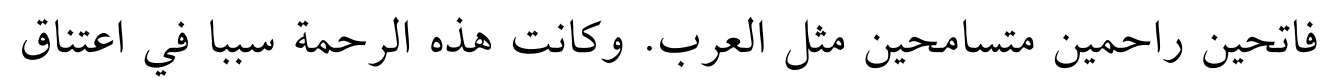

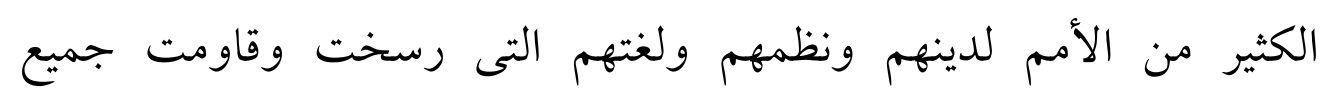

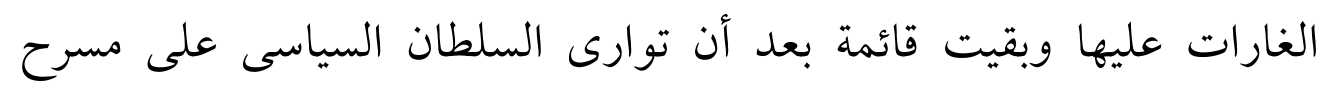

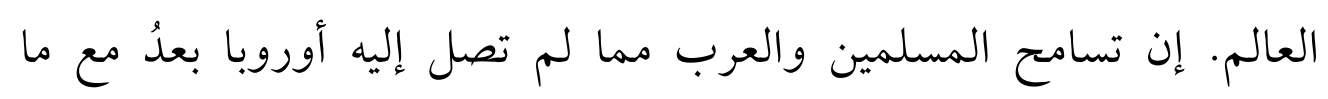
قامت به في أكثر من ألفى سنة من الحروب الطاحنة وما عانته من الأحقاد

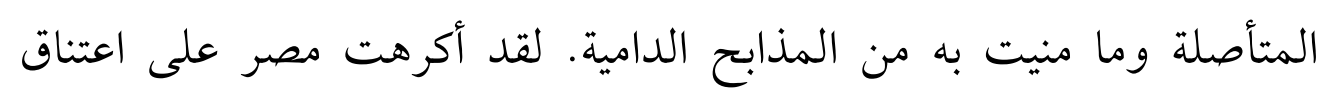

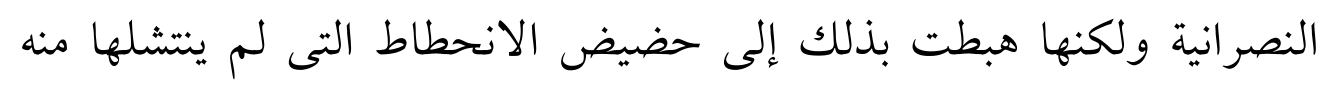

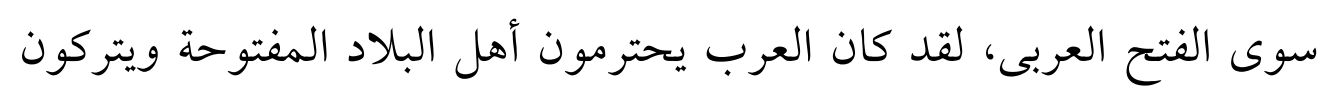

طبعة مؤسسة اقرا الطبعة الاولى سنة ه.. T م 
لهم حريتهم الدينية، فقد عامل عمرو بن العاص المصريين بما لم يعرفوه من العدل والإنصاف واحترام نظم المصريين وعاداتهم ومعتقداتهم، وشمل الديانة النصرانية بعطفه وحمايته وسمح للأقباط بأن يستمروا في اختيار بطريرك لهم، ولم يمنع النصارى من إنشاء الكنائس في المدينة الإسلامية التى أسسها المسلمون، ولذلك كان الانسجام بين العرب والأمم قويا جدا، وكان حب الأمم للعرب خالصا وأكيدا."(')ولهذا لم يعرف التاريخ شعبًا مسلمًا حاول إجبار أهل الذمة على الإسلام، كما أقر بذلك المؤرخون الغربيون أنفسهم.

يقول الشيخ محمد الغزالى -رَرَمَهُألَّهُهـ- نقلا عن بعض المؤرخين الغربين العلامة الكونت هنري دي كاستري.: "درست تاريخ النصارى في باد الإسلام، فخرجت بحقيقة مشرقة هي أن معاملة المسلمين للنصارى تدل على لطف في المعاشرة، وهذا إحساس لم يُؤثر عن غير المسلمين.. فلا نعرف في الإسلام مجامع دينية، ولا أحبارًا يحترفون السير وراء الجيوش الغازية لإكراه الشعوب على الإيمان" (؟)

إن الحرية الدينية " التي كفلها الإسلام لأهل الأرض، لم يعرف لها نظير في القارات الخمس، ولم يحدث أن انفرد دين بالسلطة، ومنح مخالفيه في الاعتقاد كل أسباب البقاء والازدهار، مثل ما صنع الإسلام" ل(ّ) (1) طابع الإسلام بين الأديان: الأستاذ أنور الجندى صـأهاءه باختصار. طبعة دار

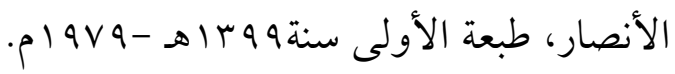

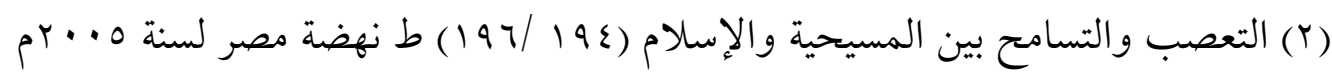
(r) حقوق الإنسان بين تعاليم الإسلام وإعلان الأمم المتحدة: الشيخ محمد الغزالي 
في الوقت الذي كان التعصب الديني قد بلغ مداه جاء الإسلام ليهتف:

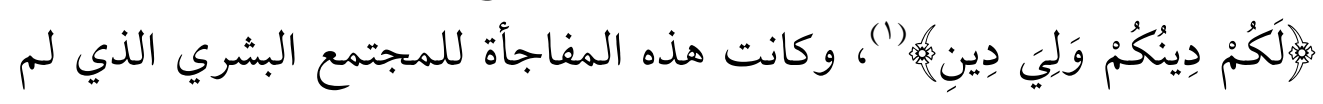

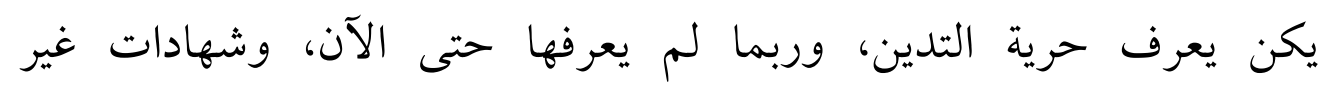

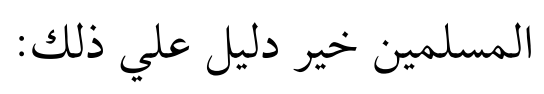

(أ) تقول المستشرقة الألمانية زيغريد هونكه: "العرب لم يفرضوا على لى

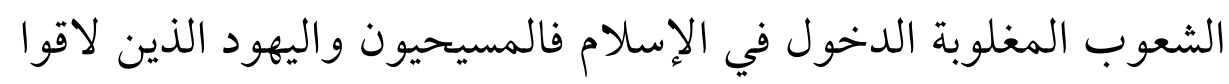

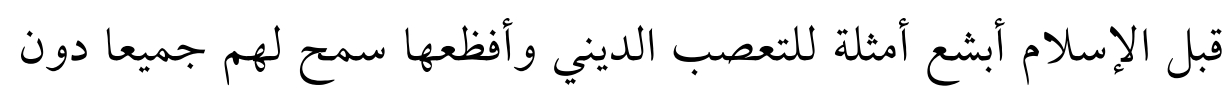

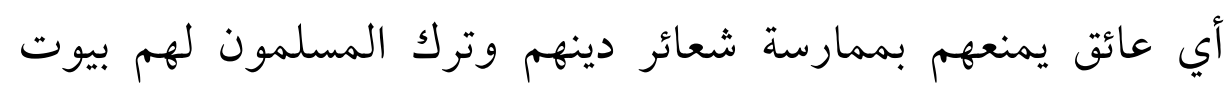

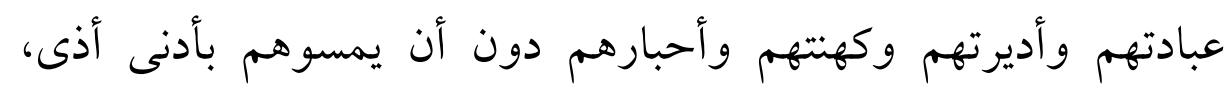

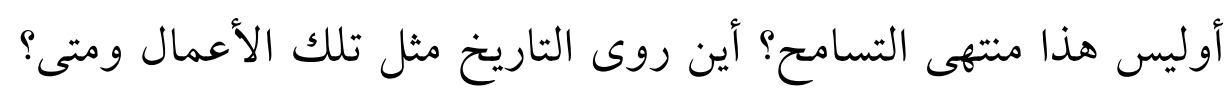

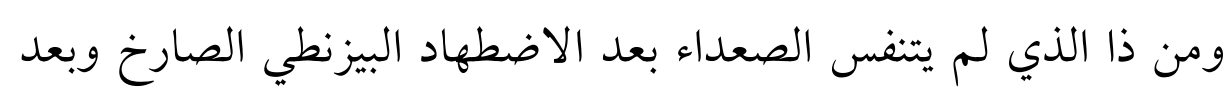

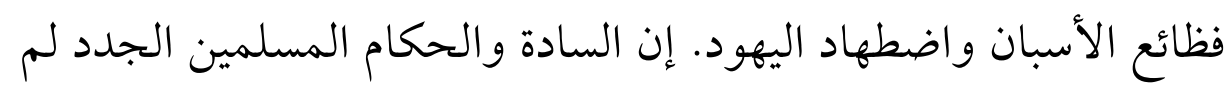

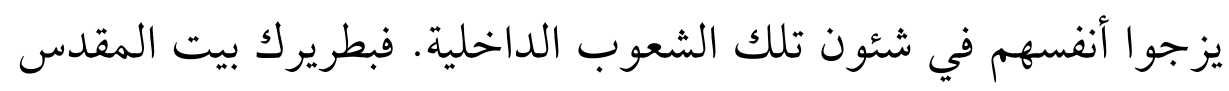

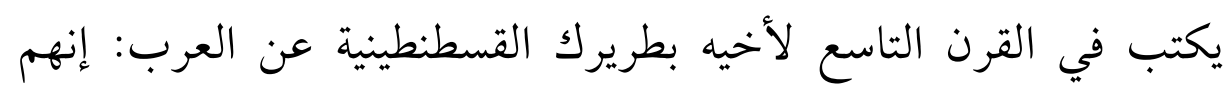

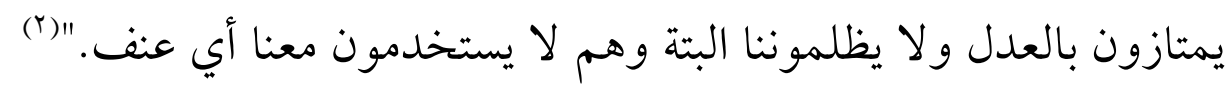
(ب) يقول غوستاف لوبون: "فالحق أن الأمم لم تعرف فاتحين راحمين

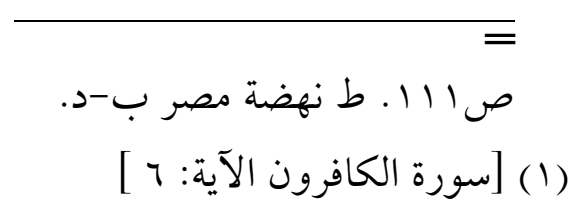

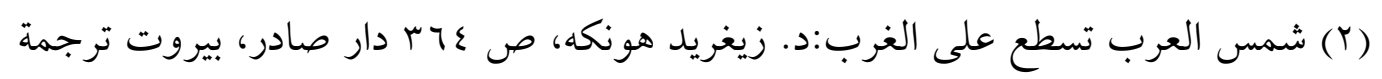

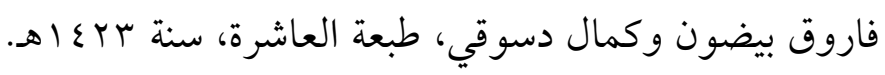


متسامحين مثل العرب و لا دينا سمحا مثل دينهم."(1) (ج) يقول هنري دي شامبون مدير مجلة "ريفي بارلمنتير" الفرنسية حيث قال: لو لا انتصار جيش شارل مارتل الهمجي على العرب المسلمين في فرنسا لما وقعت بلادنا في ظلمات القرون الوسطى ولما أصيبت بفظائعها ولا كابدت المذابح الأهلية التي دفع إليها التعصب الديني المذهبي، لو لا ذلك الانتصار الوحشي على المسلمين في بواتييه لظلت أسبانيا تنعم بسماحة الإسلام ولنجت من وصمة محاكم التفتيش ولما تأخر سير المدنية ثمانية قرون ومهما اختلفت المشاعر والآراء حول انتصارنا ذاك فنحن مدينون للمسلمين بكل محامد حضارتنا في العلم والفن والصناعة مدعوون لأن نعترف بأنهم كانوا مثال الكمال البشري

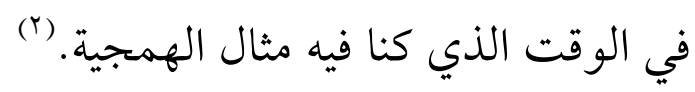
إن "عظمة هذا الدين لا تخفى إلا على من جهل حقيقة الإسلام أو عميت بصيرته عنه أو كان به لوثة من هوى أو حقد مقيت، وإلا فإن سماحة الإسلام في المعاملة وتيسيره في كل أموره، ظاهر بأدنى تأمل لمن طلب الحق وسعى إلى بلوغه. يقول الشيخ محمد الغزالى "ورأى الإسلام فى ألى عيسى بن مريم-عليه السلام-، أكرم وأشرف من رأى اليهودية التى تتملقها الكنيسة الآن على حسابنا، وتظاهر الإلحاد معها على حربنا.!! إن الإسلام (1) حضارة العرب:د. غوستاف لوبون، ص • V نقلة الى العربية الاستاذ: عادل زعتر، طبعة

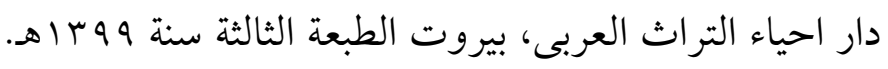

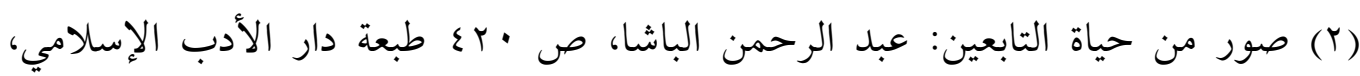

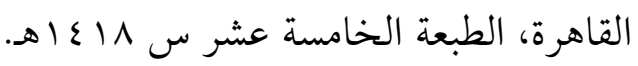


يحترم موسى -عليه السلام- والتوراة التى أنزلت عليه، ويحترم عيسى الإنى

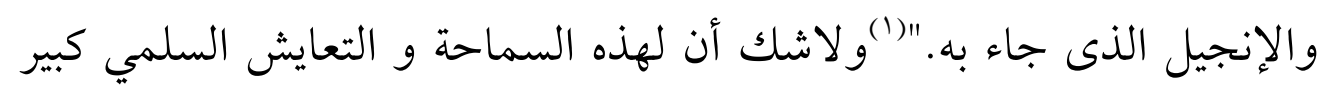

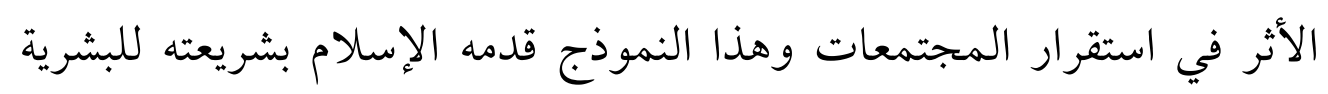
جمعاء فسعدت به واستقرت.

are?

(1) الإسلام المفتري عليه بين الشيوعيين والرأسماليين: الشيخ محمد الغزالي صعَ طبعة دار نهضة مصر الطبعة الأولي.

العدد السادس والثلاثون .r.r 


\section{المطلب الخامس}

\section{تحقيق الوسطية والاعتدال.}

الوسطية والاعتدال مقوم من مقومات الاستقرار المجتمعي، وهي

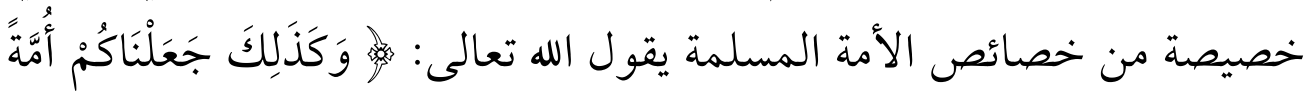

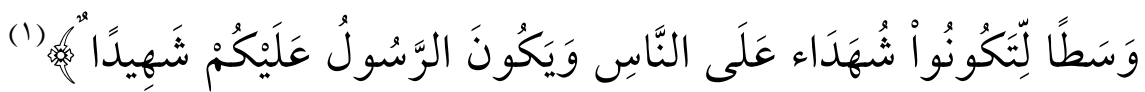

وتمثل الوسطية منطقة الأمان والبعد عن خطر التعصب الفكري، والمفاهيم الخاطئة، فهي تقيم الوزن وتضع الأمور في نصابها، حيث تعني: "المنهج القويم العدل، الذى يلاحظ الفطرة ويعالج الطبيعة، ويرد المجتمع إلى اليسر، مع التماسك ويبعده عن الفساد والانحلال مع الرحمة به والتخفيف عنه، وأن هذا لهو الصراط المستقيم الذى علم الله عباده أن الن ينشدوه، وأن يطلبوا منه هدايتهم إليه "(؟)

و الطريق إلي الاستقرار المجتمعي هو أن يتجنب المجتمع الغلو بكل

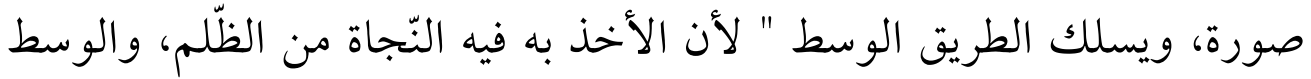
الموضوع بين طرفي الإفراط والتّفيط هو العدل وهو الّذي عليه بناء مصالح الدّنيا والآخرة، بل حتّى مصلحة البدن لا تقوم إلّا به؛ لأنّه متى خرج بعض بعض أخلاطه عن العدل وجاوزه أو نقص عنه ذهب من صحّته وقوّته بحسب

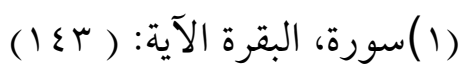

(r)وسطية الإسلام، الشيخ محمد المدني ص ع • ا طبعة دار القلم للنشر والتوزيع القاهرة،

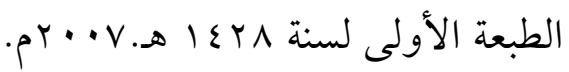


ذلك، ومثل ذلك الأفعال الطبّيعيّة كالنّوم والسّهر والأكل والشّرب والحركة

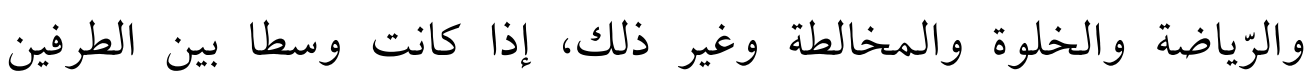

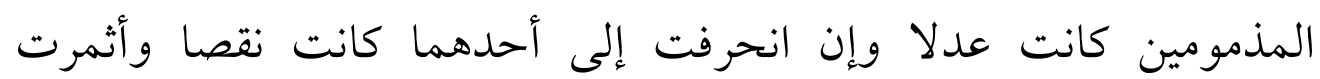
نقصا". (1)

والوسطية "من أعظم حقوق الأمة الإسلامية التي سماها الله أمة وسطا

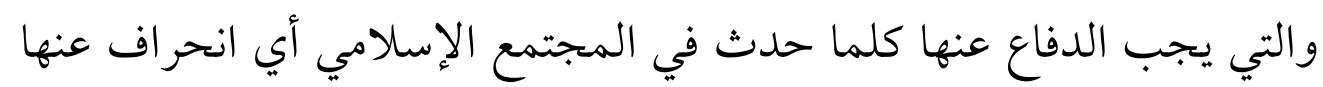

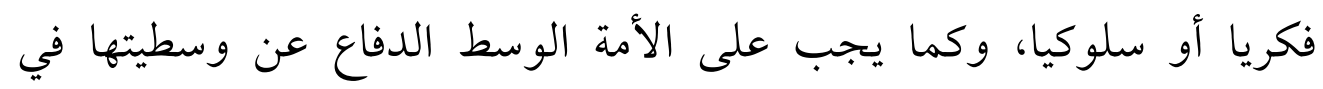

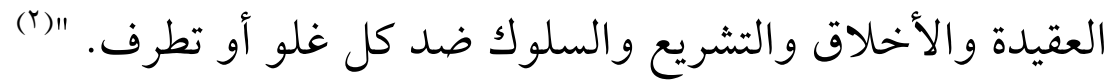
ولقد حفظت الوسطية المجتمع من الغلو والتطرف، والفهم الخاطئ

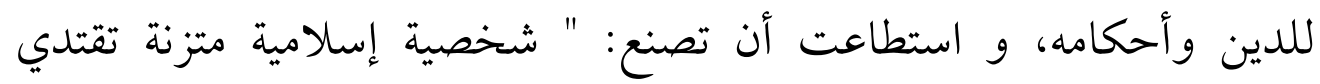

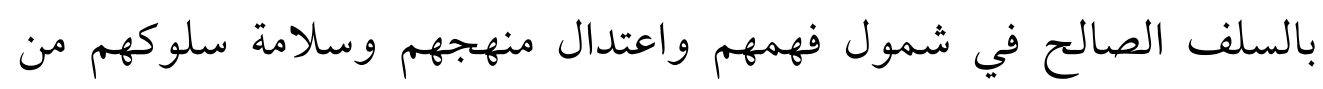
الإفراط والتفريط، والتحذير من الشطط في أي جانب من جول فوانب الدين،

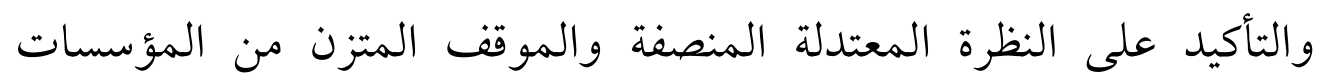

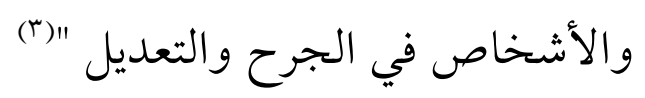

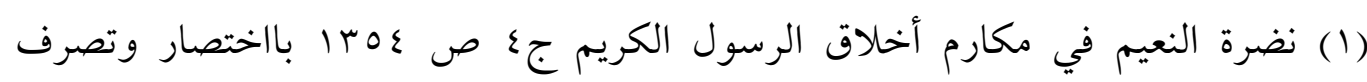

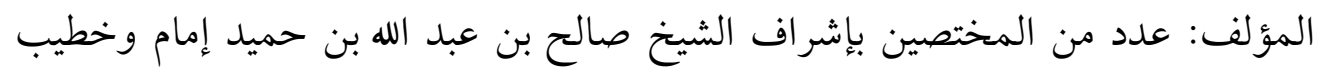

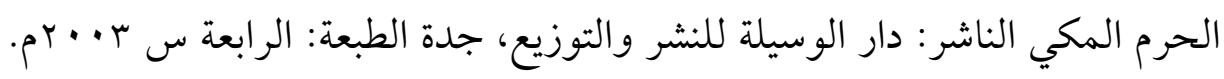

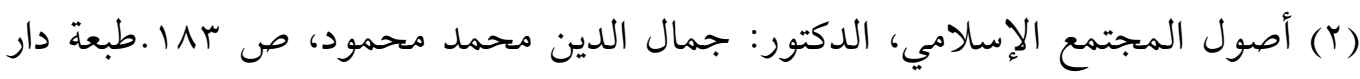

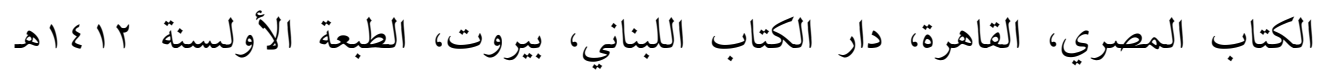
. (r) الر ائد دروس في التربية والدعوة: الشيخ: مازن بن عبد الكريم الفريح، جr ص 9 / اط 
والمجتمع اليوم أحوج ما يكون إلى العودة إلى تطبيق الوسطية حيث إن هناك انحرافًا فى بعض القضايا الفكرية والعملية، والسبب فى ذلك ذلك هو إلى الغلوو التعصب وعدم الفهم الصحيح للشريعة وأحكامها. والذى ينظر فى التاريخ يرى هذا واضحا، ففي آخر عهد الخليفة عثمان بن عفان-رضى الله عنه- ظهرت الفتنة بالانحراف عن هذا المنهاج الوَسَطيّ في الدعوة، وأطلت الفتنة برأسها، وانتهت بمقتل الخليفة الثالث سيدنا عثمان بن عفان ظلمًا وعدو وعنًا. وكانت هذه بداية الفتنة الكبرى في تاريخ الإسلام، وذلك حينما انحرفت دعوة الإصلاح أو الدعوة إلى الأمر بالمعروف والنهي عن المنكر عن الوجه الشرعي الصحيح، وظهر فكر ألخوارج (1)، والذى كان فيه انحراف عن منهاج الوسطية في الدعوة إلى الله، فكان ظهورهم انحرافًا عن منهاج الإسالام في

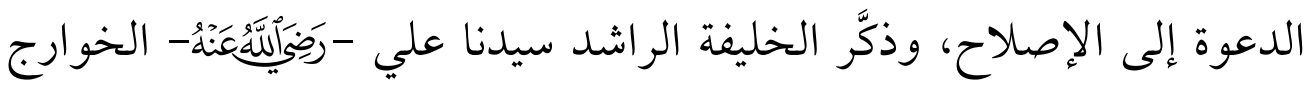
بهذا المنهاج الأقوم والأرشد، ولكنهم تنكبوا الطريق، وعَدَوا على ولي الأمر وخليفة المسلمين بعد أن بايعه الناس ورضوه إماما لهم، وكان مسلكهم فيما يتظاهرون به من الدعوة إلى الله، على ما تحكي كتب التاريخ الإسالمي،

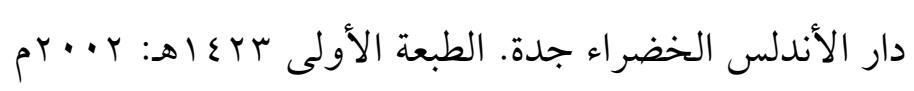

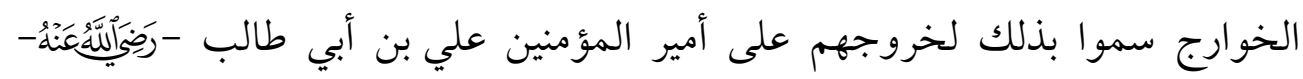

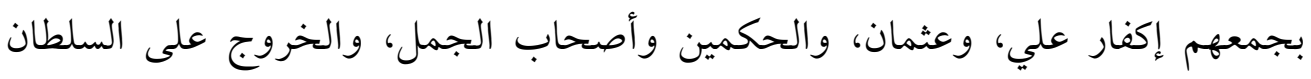

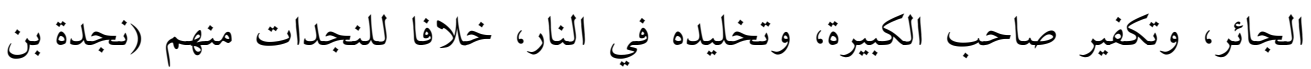

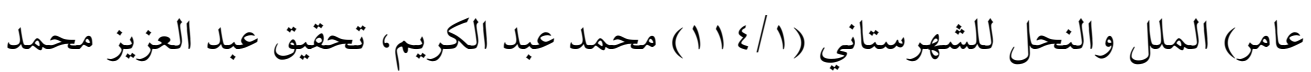
الوكيل، مؤسسة الحلبي وشركاه، 
واضح البطلان والزيف. كانوا يتمسكون لفظًا بشعارات الإسلام، ويرتكبون عمدًا ما تنكره فرائض إنض

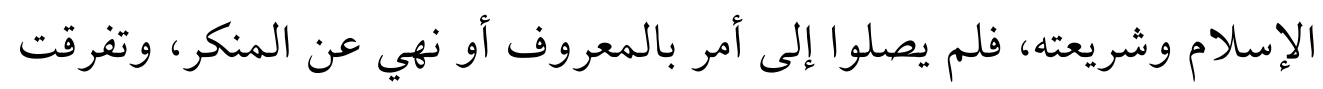

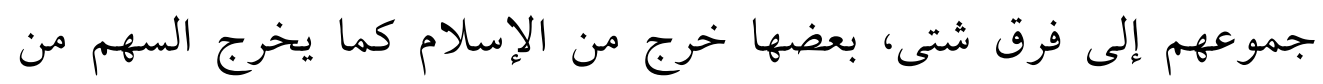

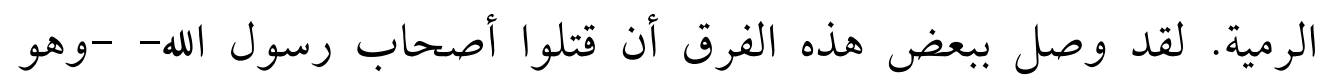

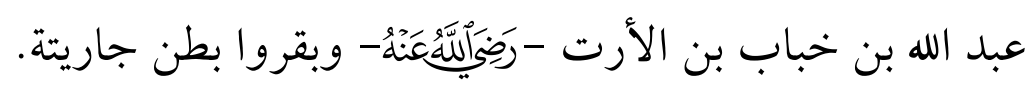

وفي العصر الحديث ظهر الغلو والتطرف، حيث ابتلي العالم الإسلامي

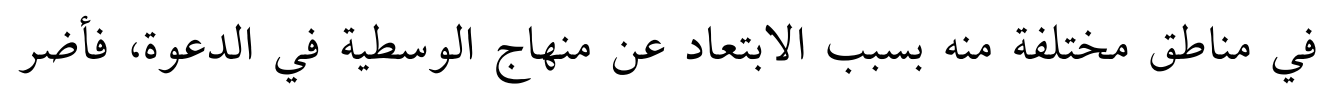
ذلك بالإسلام ودعوته.

فهناك من فرطوا في الدين، وسعوا إلى تبديل حكم الله، واتباع الأهو اء،

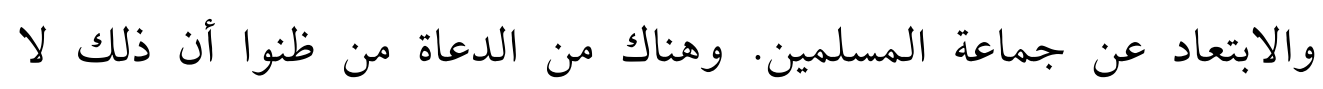
يصلحه إلا التشدد والغلو، واتهام الناس بالكفر والمروق من الدين، ودناء وإباحة دمائهم وأمو الهم دون دليل شرعي صحيح.

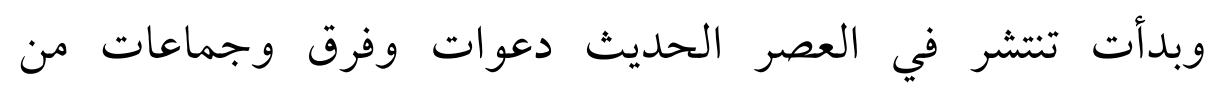
المسلمين، تجانب الوسطية في دعوتها، وهذه صور من الانحر اف عن منهاج

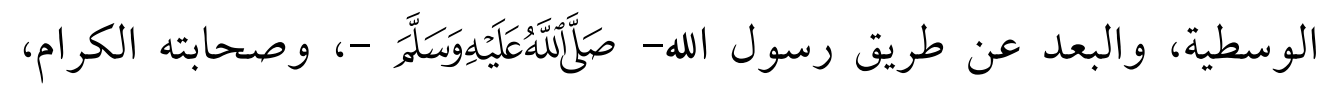

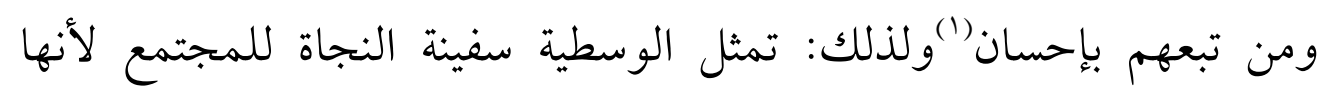

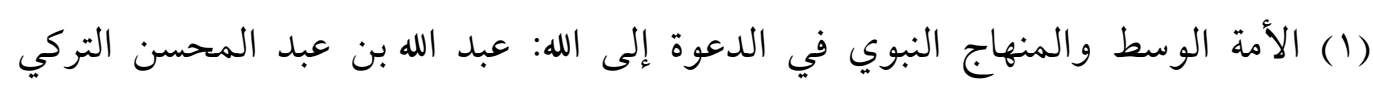

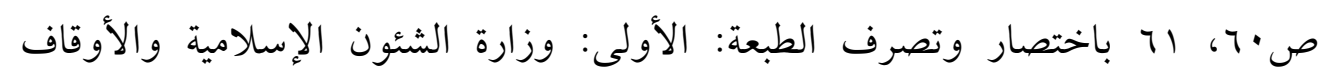

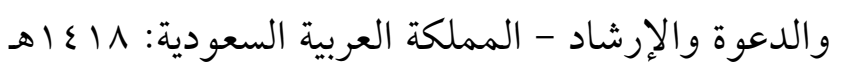




$$
\text { والتشدصد، والتي تحد إلى بر الأمان حيث الاستقرار، والبعد عن كل أشكال الغلو }
$$

G(1) 


\section{المبحث الثالث}

الاستقرار المجتمعي في ضوء مقاصد الشريعة.

$$
\text { وَهُوَ مُرَتبّب على مطلبين: }
$$

المطلب الأول: المقاصد الضرورية وتحقيق الاستقرار المجتمعي.

المطلب الثاني: المقاصد العامة وتحقيق الاستقرار المجتمعي. 


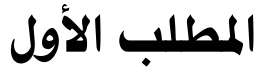

\section{المقاصد الضرورية وتحقيق الاستقرار المجتمعي.}

مقاصد الشريعة باب واسع؛ لكنه في مجمله يثمر إنساناً صالحاً، و

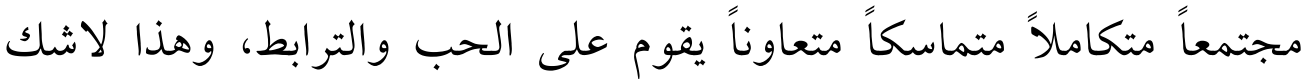

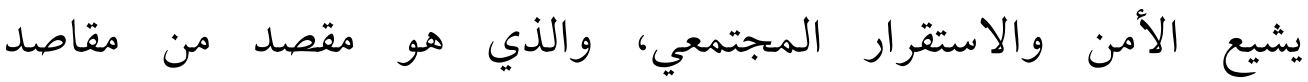

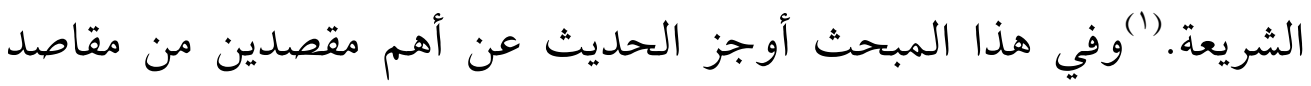
الشريعة وهما: المقاصد الضرورية، وبعض المقاصد العامة.

والمدقق في الشريعة الإسلامية وأحكامهايجد أنها جاءت لتنظم للناس

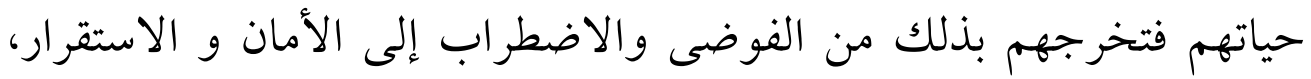

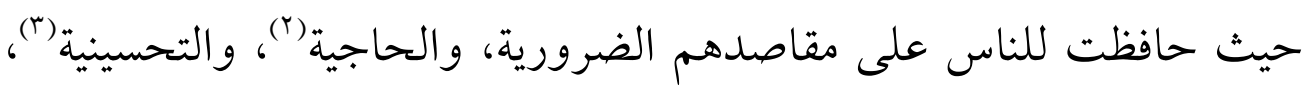

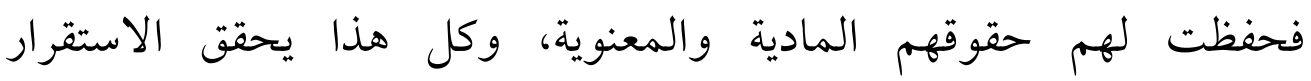
المجتمعي ويرسي دعائمه.

ومصالح الناس مبنية على هذه الضروريات حيث:يقول الإمام أبو حامد

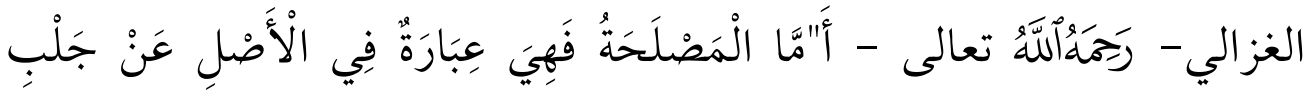

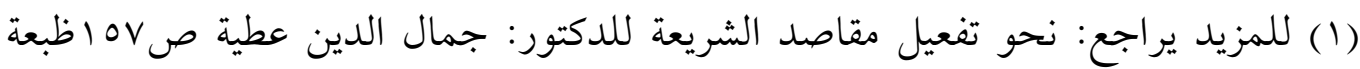

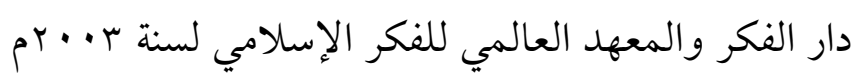

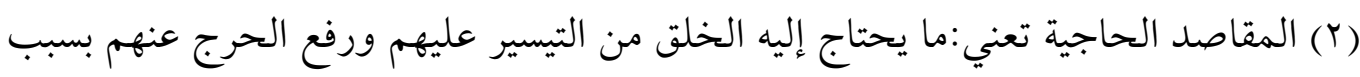
احتمال مشاق التكليف وصعوبة الحياة. (r) المقاصدالتحسينية تعني: ما تقتضيه المروءة لسير الحياة على أحسن وجه. 


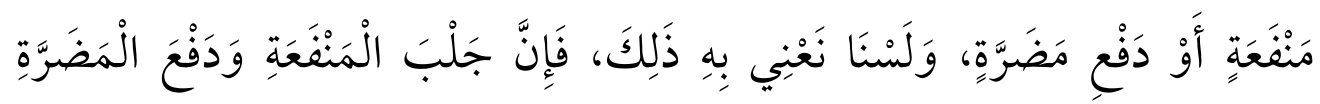

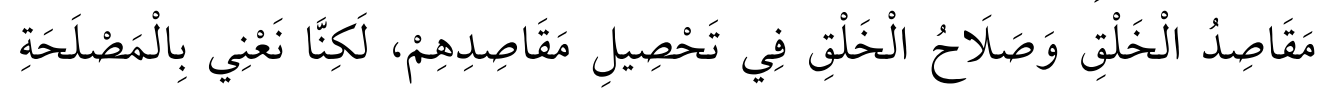

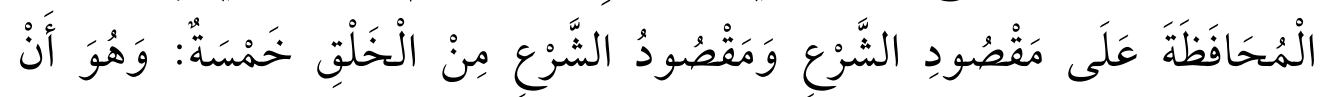

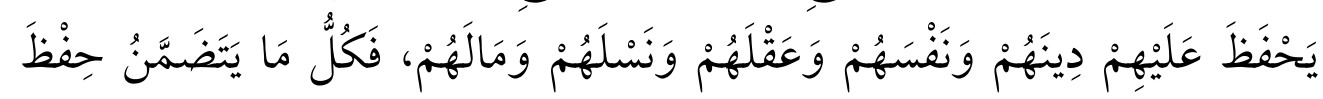

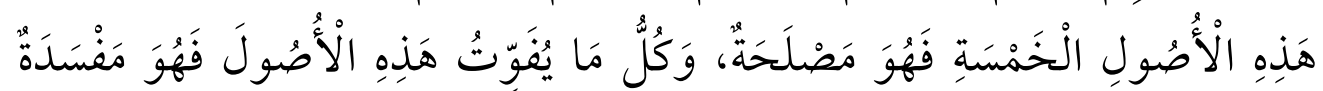

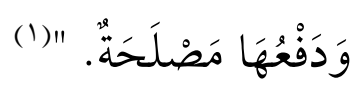

وينبه الإمام الشاطبي -رَرَمَهُأَلَّهُهـ- إلي أهمية المقاصد الضرورية في حياة

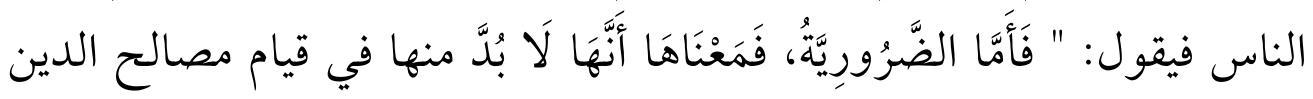

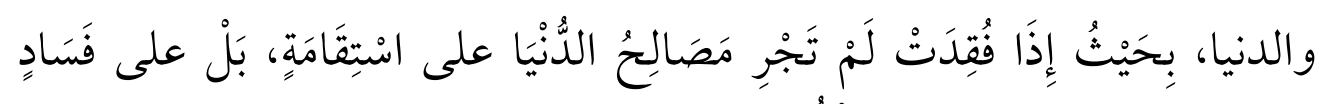

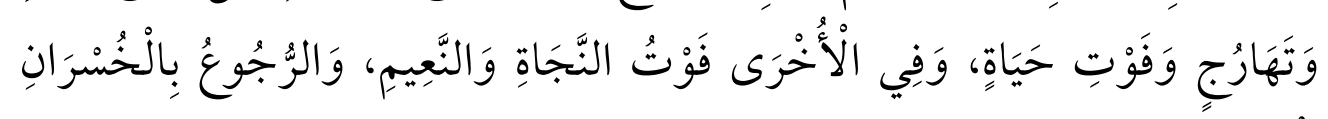
(ب)" الْمُبِينِ.

وهذه الضروريات: "ترجع إلى المحافظة على أمور خمسة الدين

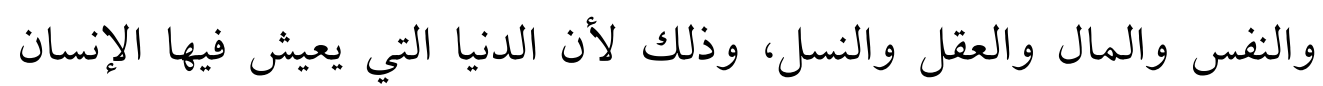

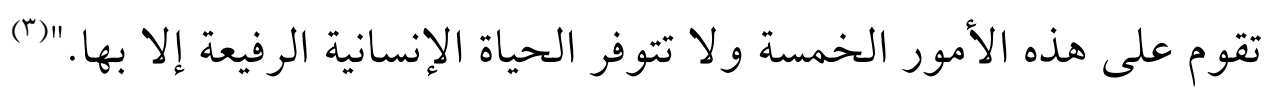
و"الشريعة الإسلامية تتجه في كل أحكامها إلي تحقيق هذه الأهداف

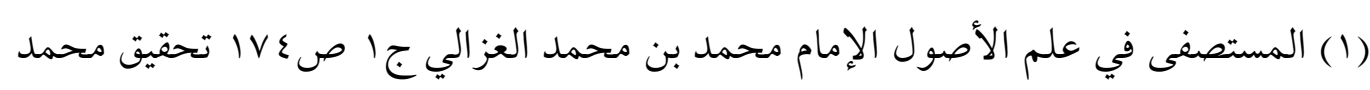

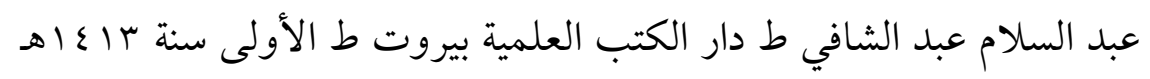

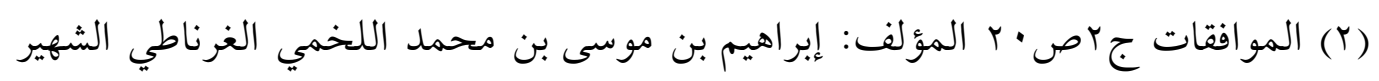

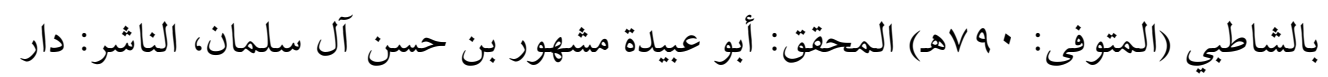

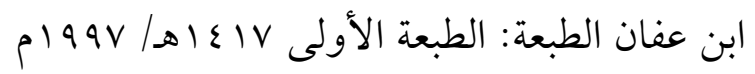

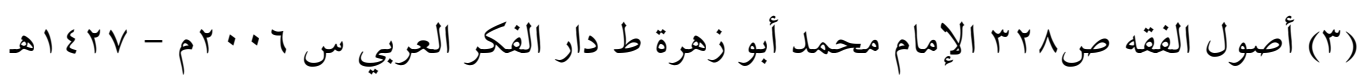


الاجتماعية، وهي المقاصد العليا للشريعة فقد جاءت لتكوين مجتمع فاضل يضم الإسرة الإنسانية كلهاقاصيها ودانيها، وابتدأت فاتجهت إلي تربية

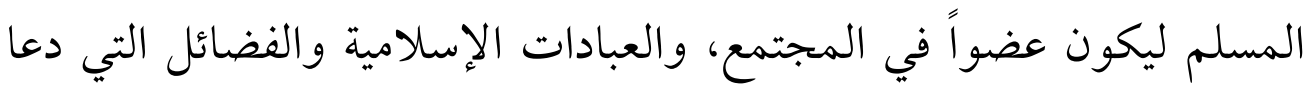
إليها الإسلام تتجه نحو هذه الأهداف" (1)

وترتبط" كلّ من هذه المقاصد الخمس بعدد من الجوانب ذات الطبيعة

الاجتماعيَّة، فحفظ الدّين يرتبط بإقامة شعائر الله تعالى وتعاليمه، بما فيها مكارم الأخلاق والمعاملات، وهي الضمانة الأساسيَّة لاستقرار أيّ مجتمع وصيرورته بشكلٍ سويٍّ، والحفاظٍ على النسل يرتبط بالحفاظ على النسب والعرض، بما يضمن أيضًا استقرار المجتمع الإنساني، كذلك الحفاظ على المال يرتبط بالكسب الحلال والإنفاق الرشيد، وما يرتبط به ذلك من تكافل مجتمعي. (r)وبالنظر إلي هذه المقاصد بشيء من التفصيل سنجد ذلك واضحاً: متحي:

\section{أولاً:حفظ الدين.}

لقد حرصت الشريعة على استقرار المجتمع وذلك بحفظها للدين، حيث وضعت بعض التدابير الوقائية والعلاجية والتي منها:

أ- بناء وترسيخ وتحقيق الإيمان وأركانة. (؟)

(1) تتنظيم المجتمع محمد أبو زهره ص 17

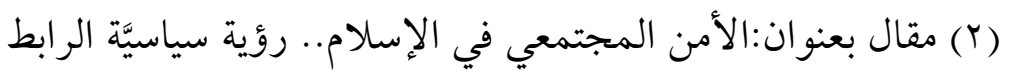
/https://basaer-online.com/2011/09/2011-09-21-20-49-35 (r) والإيمان هو المقوم الأول للاستقرار المجتمعي كمامربنا في مبحث مقومات الاستقرار. 
ب- إقامة الشعائر التعبدية من: صلاة، وزكاة، وصوم، وحج حيث تهذيب السلوك:

فنجد مثلاً:أن من مقاصد الصلاة: أنها تحقق آثاراً اجتماعية وإنسانية،

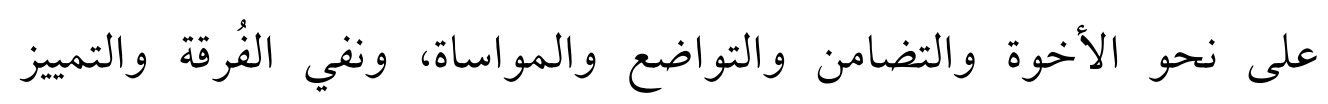
والتفرقة بسبب الجنس أو اللون أو الغنى أو الفقر أو الجاه أو المحسوبية. و نجد من مقاصد الزكاة: تحقيق أواصر التضامن والتآلف والتراحم

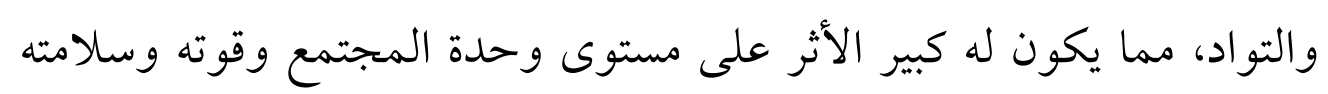

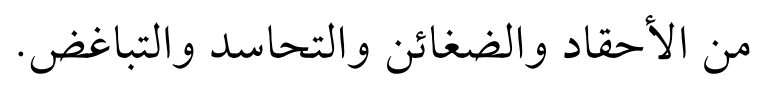
وتنمية المجتمع وتطوير تجاراته وصناعاته ومهنه وحرفه وتقوية

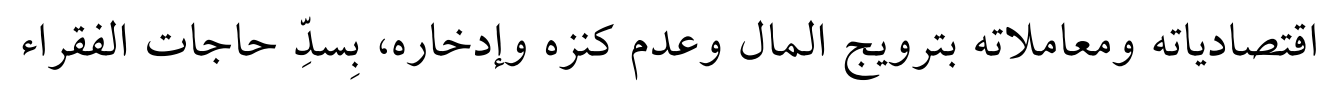

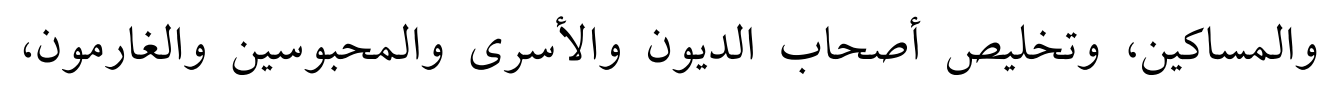

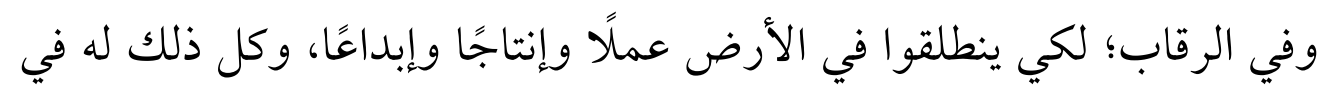

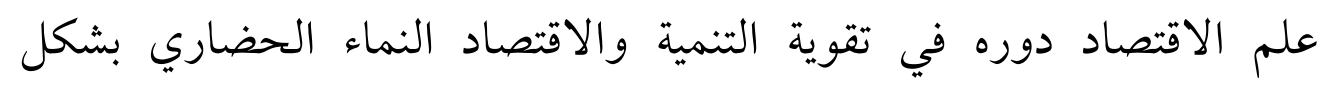

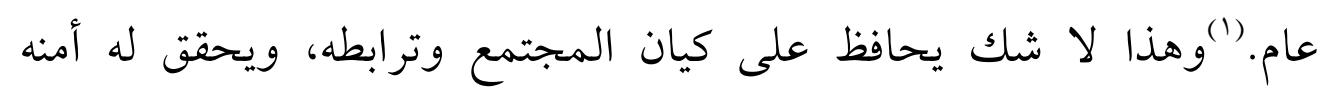
ورخائه وسعادته.

\section{ج-بناء منظومة للقيم الأخلاقية.}

والأخلاق"هي:الاساس الأول لبناء المجتمع، وقد عمل الإسلام على لى

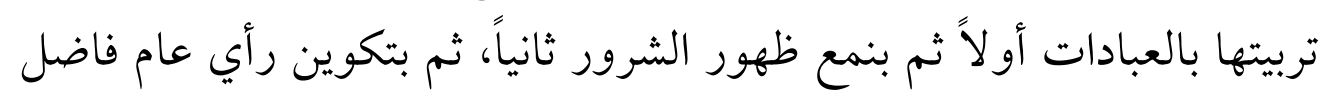

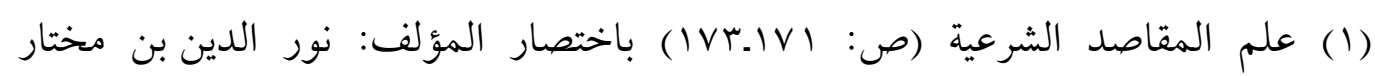

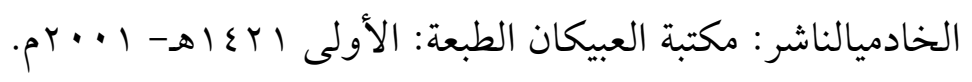


(1)" ثنالثا.

ومن هذه الأخلاق التي جاءت بها الشريعة: العفة، والصدق، والحلم، والصبر، والرحمة، والتكافل، والعدل والإحسان،والبر، والأمانة، والوفاء، والحياء، والتواضع، والشجاعة، والبذل، والمروءة، والسماحة، والنصيحة والتعاون، وصلة الأرحام، وإكرام الجار، والإحسان إلى الخلق كافة، وهذه القيم الخلقية تعود أثارها إلي المجتمع، فنتث فيه روح التعاون والتسامح والمحبة، حيث من وظائفها أنها:

1- تحفظ على المجتمع تماسكه، فتحدد له أهداف حياته، ومثله العليا، ومبادئه الثابتة المستقرة التي تحفظ له هذا التماسك والثبات اللازمين لممارسة حياة اجتماعية سليمة ومتو اصلة.

ץ- تساعد المجتمع على مواجهة التغيرات التي تحدث فيه، بتحديدها الاختيارات الصحيحة والسليمة التي تسهل على الناس حياتهم، وتحفظ على المجتمع استقراره وكيانه فى إطار موحد.

r- تربط أجزاء ثقافة المجتمع بعضها ببعض حتى تبدو متناسقة، كما أنها

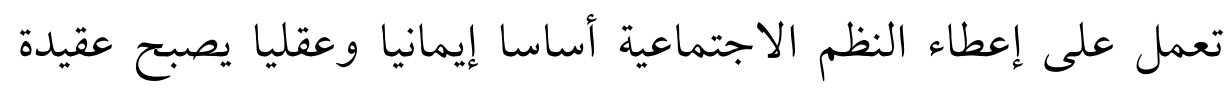
فى ذهن أعضاء المجتمع المنتمين والمتفاعلين بهذه الثقافة. ع - تقي المجتمع من الأنانية المفرطة، والنزعات، والأهواء والشهوات الطائشة التى تضر به وبأفراده ونظمه، فهي تحمل الأفراد على التفكير فى أعمالهم على أنها محاولات للوصول إلى أهداف هى غايات فى لى (1) تتنظيم المجتمع محمد أبو زهره ص • باختصار. 
حد ذاتها، وليس على أنها مجرد أعمال لإشباع الرغبات والشهوات.

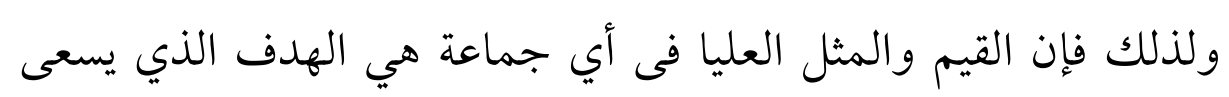

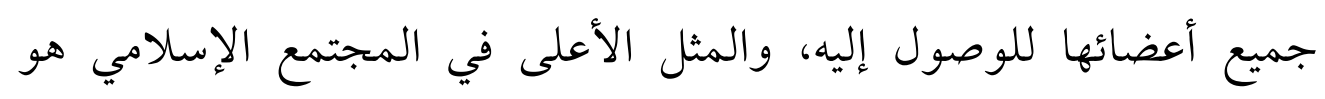

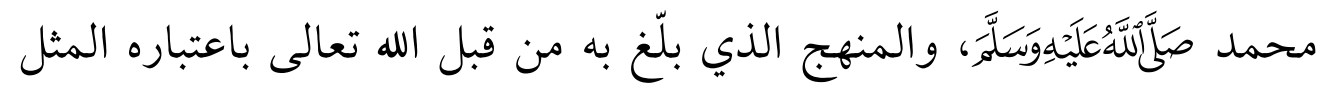
الأعلى.

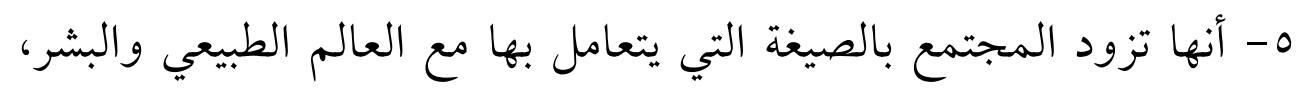
وتحدد له أهداف ومبررات وجوده، حتى يسلك في ضئه ضونهما،

$$
\text { ويستلهمها الأفراد فى سلوكياتهم. }
$$

1- أنها تزود المجتمع بالصبغة الملائمة التي تربط بين نظمه الداخلية من

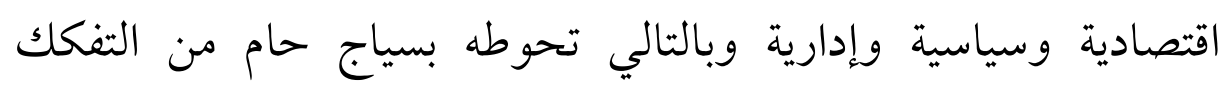

$$
\text { والانحلال. (1) }
$$

د- كفالة الشريعة للناس حرية العقيدة وحمايتها:

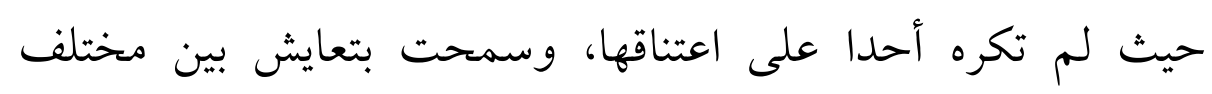

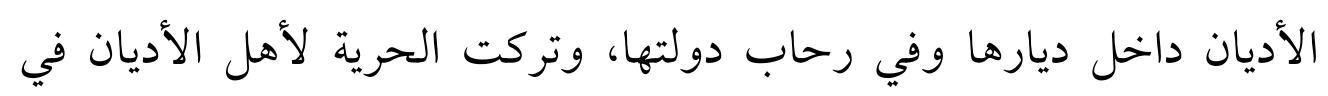

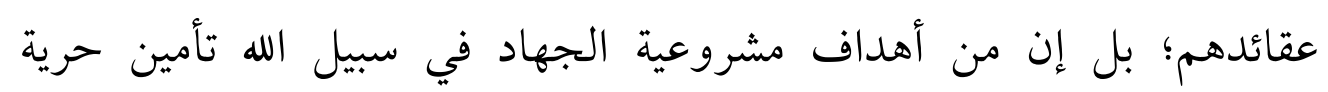

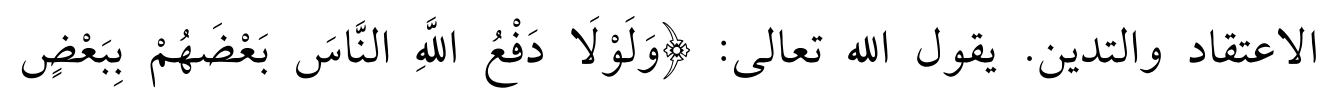

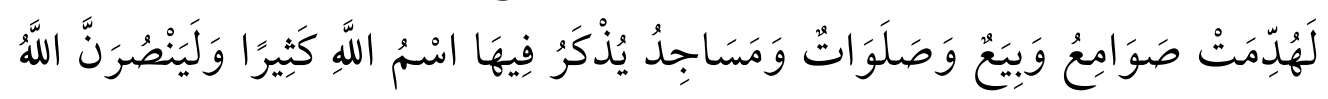
(1) نضرة النعيم في مكارم أخلاق الرسول الكريم (1/ ج) المؤلف: عدد من المختصين

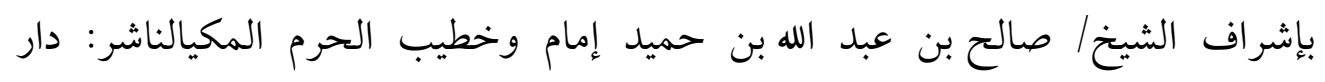
الوسيلة للنشر والتوزيع، جدةالطبعة: الرابعة. 


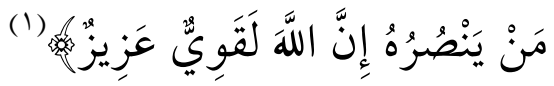

وحركة الفتح التى قام بها الصحابة -رضى الله عنهم - تشهد على احترام

الإسلام للأديان الأخرى، وحرصهم على عدم إكراه أحد في الدخول في

لقد كان أهل الكتاب يمارسون شعائر دينهم وطقوس عبادتهم في معابدهم وبيوتهم، ولم يمنعهم أحد من ذلك لأن الشريعة الإسلامية حفظت لهم حق الحرية في الاعتقاد، وفي عهد عمر بن الخطاب إلى أهل إيلياء

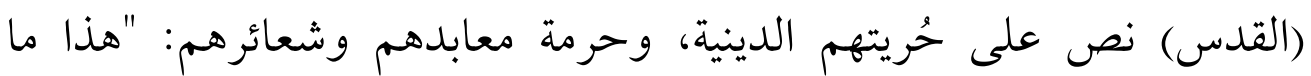
أعطى عبد الله عمر أمير المؤمنين أهل إيلياء من الأمان: أعطاهم أمانًا لأنفسهم وأمو الهم وكنائسهم وصلبانهم وسائر ملَّتها، لا تُسكن كنائسهم، ولاء الا تُهدم ولا ينتقص منها، ولا من حيزها، ولا من صليبها، ولا من شيء من أموالهم، ولا يُكرهون على دينهم، ولا يُضار أحد منهم. ولا يسكن بإيلياء معهم أحد من اليهود.."(r) و لا شك أن هذه المعاملة ساعدت ولى على استقرار المجتمع والتعايش السلمي. هـ- شرعت الأمر بالمعروف والنهي عن المنكر لطهارة المجتمع ونظافنه من

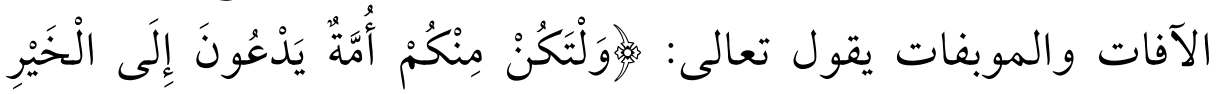

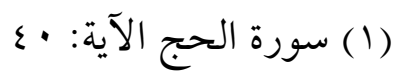

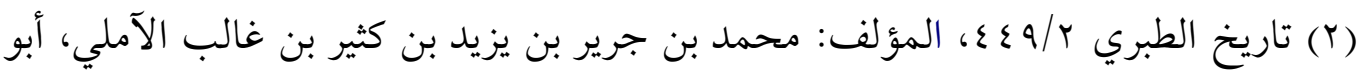

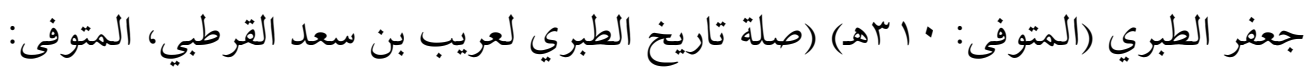

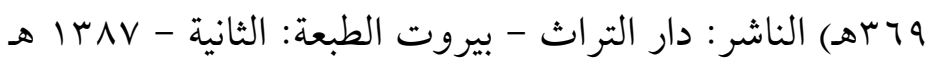




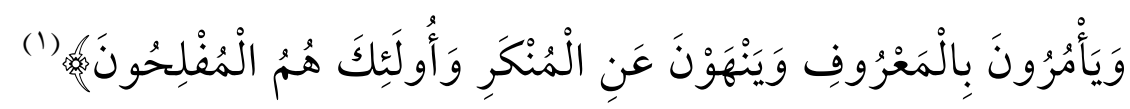

$$
\text { و - تشريع الجهاد تمكينا للدين ودرءًا للعدوان. }
$$

ل- حرمت الفواحش ما ظهر منها وما بطن وشرعت عقوبات لمن يقترفها. كل هذه الإجراءات وغيرها لا شك تقوي مقومات الاستقرار، وتحفظه

$$
\text { من الانهيار، وتضمن له القوة والاستمرار. }
$$

\section{ثانياً :حفظ النفس.}

لقد حرصت الشريعة على استقرار المجتمع وأمنه بحفظها للنفس حيث

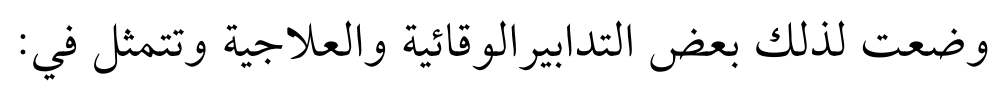

أ- تحريم الاعتداء عليها والمراد: بالاعتداء عليها بسفك دمها أو جرحها، أو

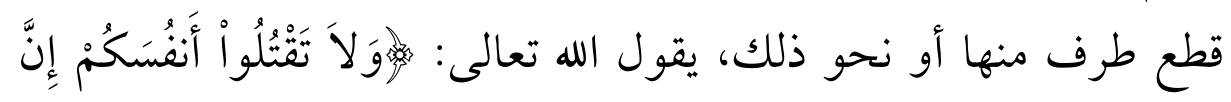

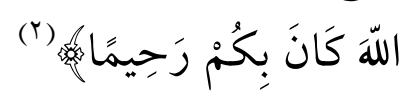

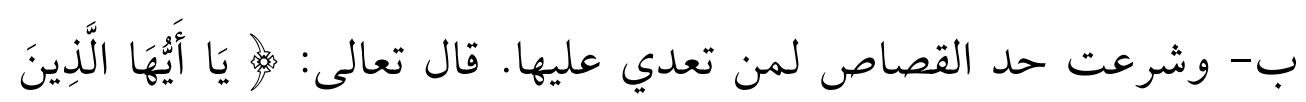

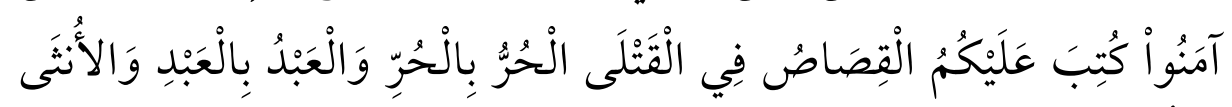

$$
\text { بالأُنَى (r) }
$$

ج- وشرعت حد الحرابة حتى لا ينتشر في المجتمع الفوضى والاضطراب

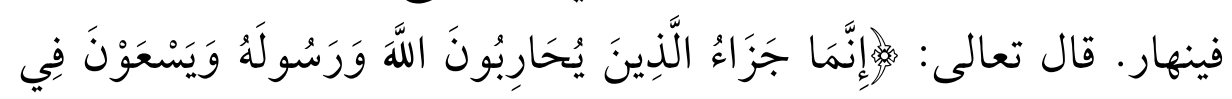

$$
\begin{aligned}
& \text { (1) (سورة ال عمران الآية: ع • 1) }
\end{aligned}
$$

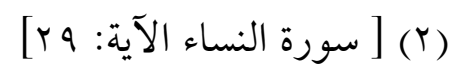

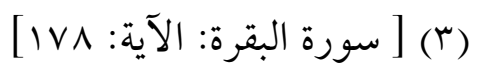




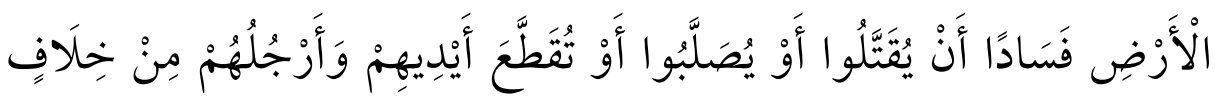

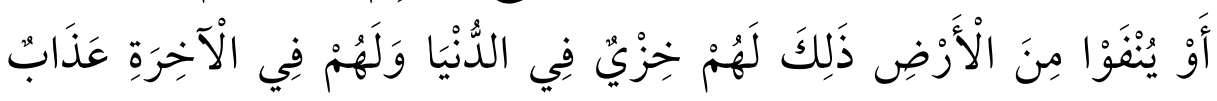

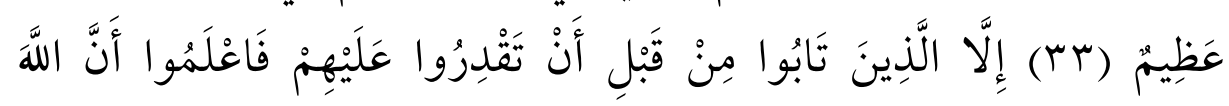

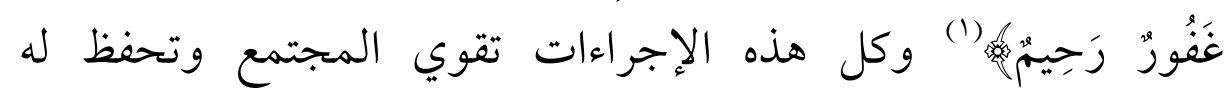
استقراره وأمنه.

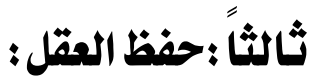

لقد حرصت الشريعة على استقرار المجتمع وأمنه بحفظها للعقل حيث

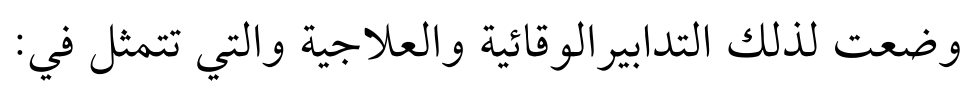

تحريم كل ما من شأنه أن يؤثر على العقل ويضر به سواء كان هذا

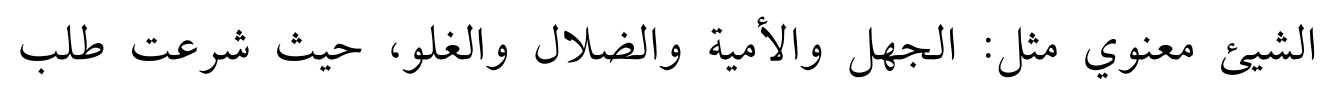

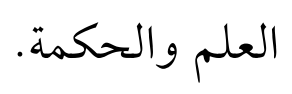

وكذلك حرمت على العقل كل ما فيه ضرر مادي مثل: الخمر

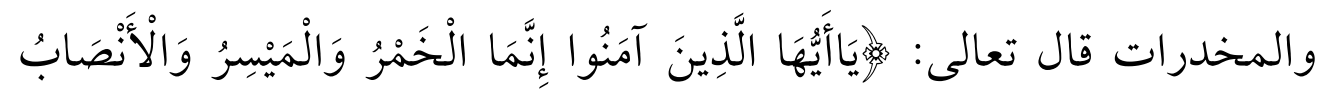

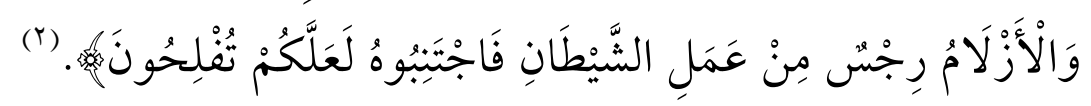

حيث لا يقتصر ضرر الخمر والمخدرات على الفرد المتعاطي، وإنما

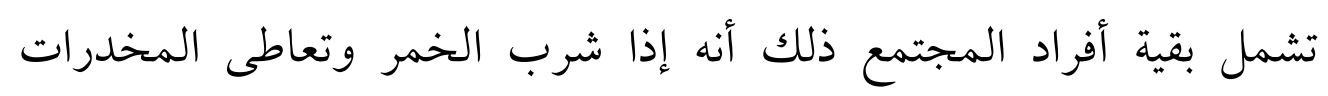

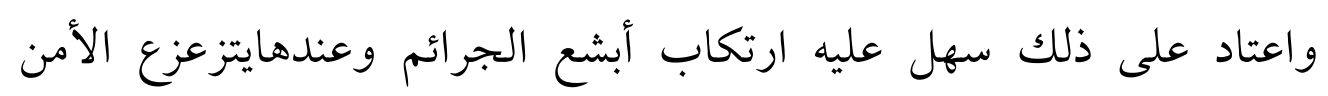
ويضطرب الاستقرار وتتخلخل قاعدة المجتمع ويتفكك بنيانه.

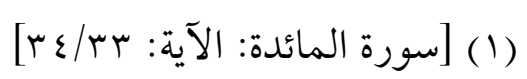

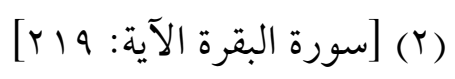




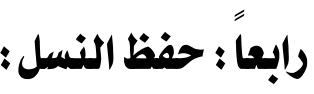

لقد حرصت الشريعة على استقرار المجتمع وأمنه بحفظها للنسل حيث وضعت لذلك بعض التدابير الوقائية والعلاجية والتي منها:

أ- الزواج: حيث الاستقرار وطمأنينة النفس وبناء الأسرة، وتحقيق السكن والمودة والرحمة بين الزوجين، وتحقيق التآلف والتعاون ودوام العشرة. فالأسرة هي: العامل الأول للاستقرار عندما يتوافر فيها الحب والوئام

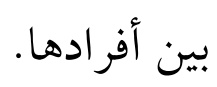

ب- شرعت حد القذف حيث يعاقب القاذف بالجلد ثمانين جلدة، قال

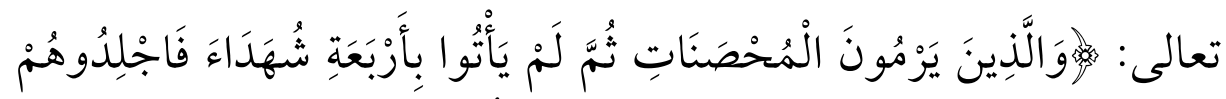

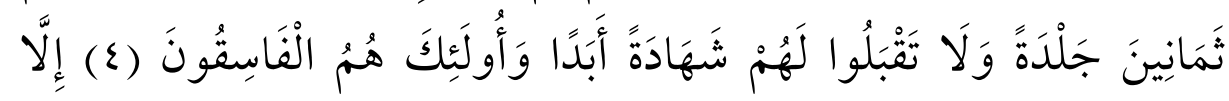

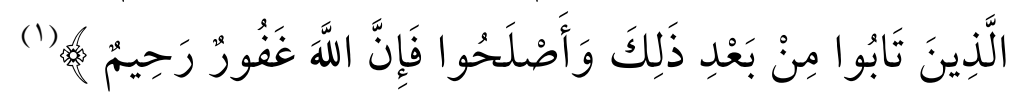
ج- وشرعت حد الزنا، حيث وضعت الشريعة الأطر التي تحافظ على سياج

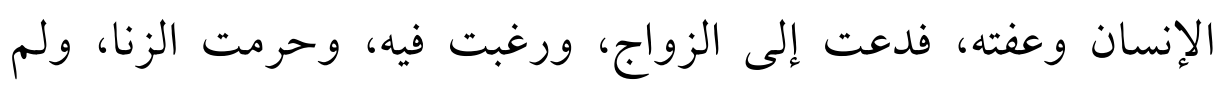
تقف عند هذا الحد، بل حرمت مقدماته ووسائله التي تؤدي إليه، قال

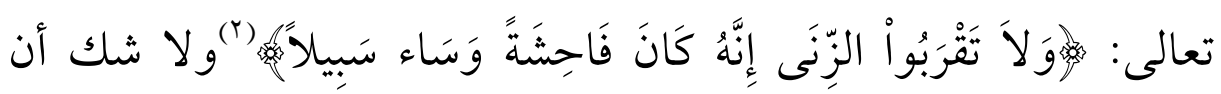
كل هذا يعززقيمة العفة في المجتمع.

$$
\begin{aligned}
& \text { (1) [سورة النور: الآية: ع/0] }
\end{aligned}
$$

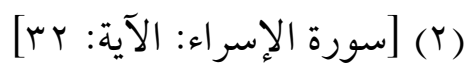




\section{خامساً: حفظظ المال. - خام.}

لقد حرصت الشريعة على استقرار المجتمع وأمنه بحفظها للمال حيث وضعت لذلك بعض التدابير الوقائية والعلاجية والتي منها:

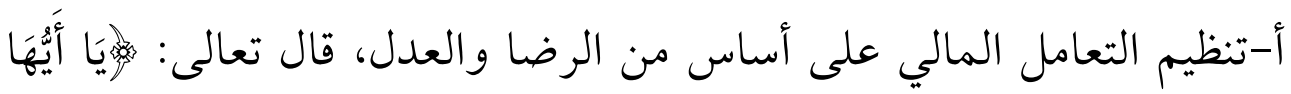

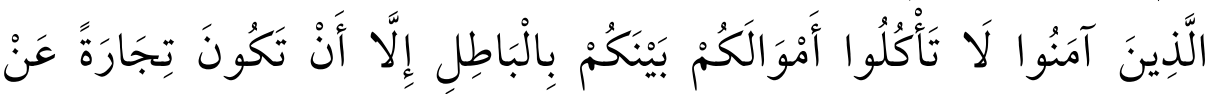

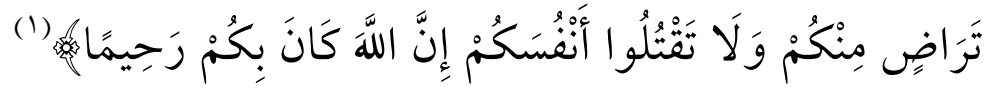

ب-ضبط التصرف في المال بحدود المصلحة العامة ومن ثم حرم اكتساب الماب

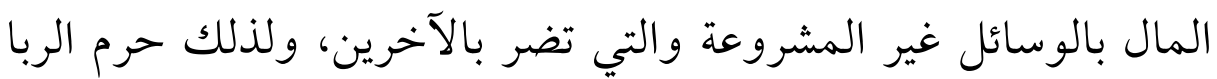
التطفيف في الميزان وحرم الإسراف.

ج- تحريم السرقة، والسرقة كبيرة من الكبائر التي وضع الله سبحانه لها عقابًا

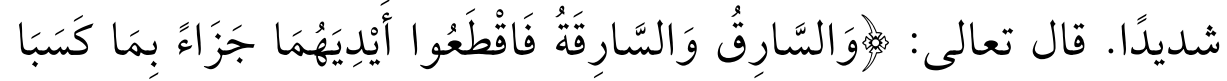

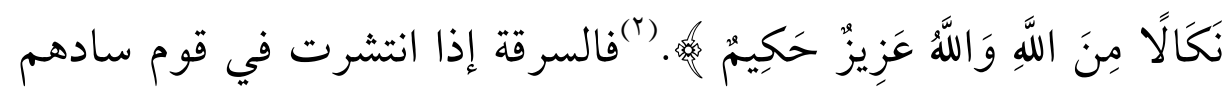

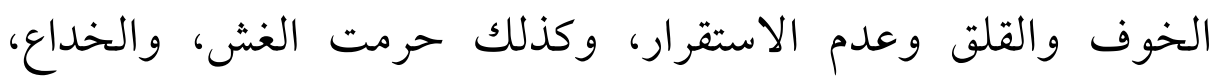
والغرر، وكل حيلة يأكل بها الإنسان مال الناس بالباطل. وكرد. وبعد هذا العرض للمقاصد الضرورية نسطتيع أن نحدد المحاور

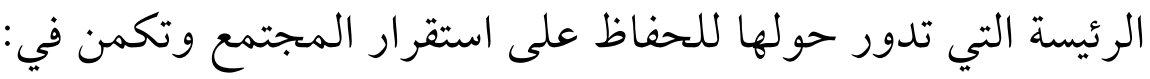

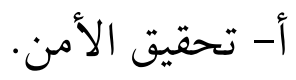


كل فرد يحتاج إلى الطمأنينة التي تنفي الخوف والفزع عنه، في سائر

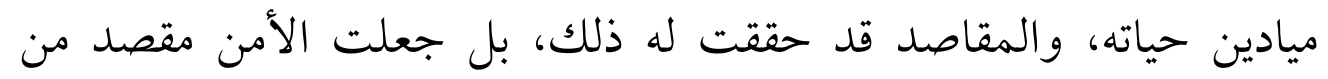

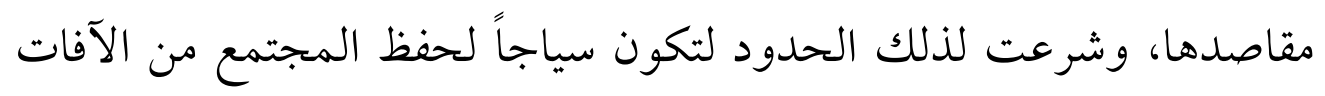

$$
\text { والموبقات. (1) }
$$

حققت المقاصد الضرورية للفرد التوازن(r)، والذي هو طابع الشريعة

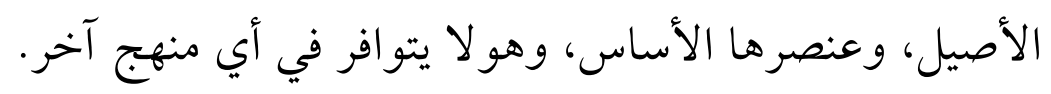

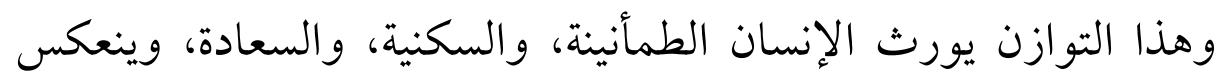
ذلك على سلو كه وعلى من حوله فيتحقق بذلك الاستقرار.

فالتوازن هو السنة التي دونها يستحيل أن يكون هناك وجود حقيقي

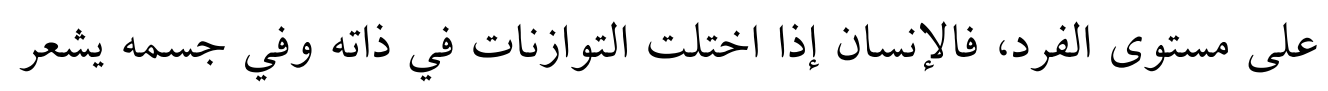

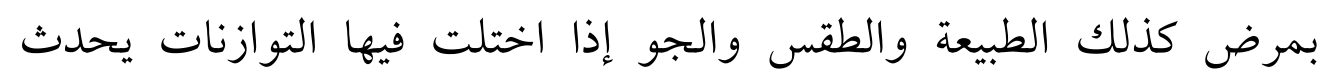

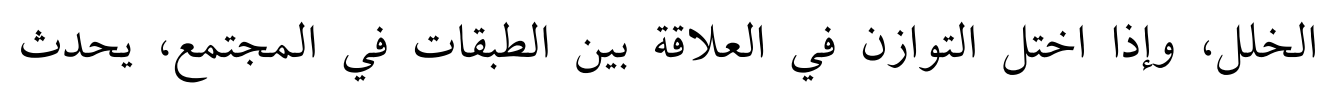

(1) فالحدود تعني: دقة التشريع الجنائي وعمقه وحمايته للأمن الاجتماعي والسياسي

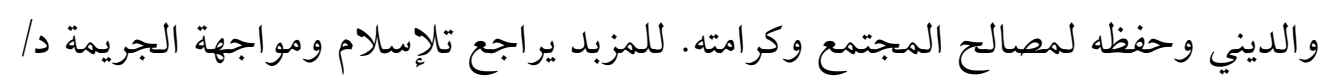

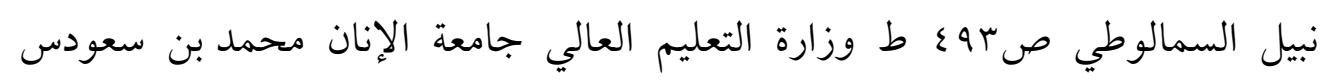
مان 1999

(r) فالحدود تعني: دقة التشريع الجنائي وعمقه وحمايته للأمن الاجتماعي والسياسي

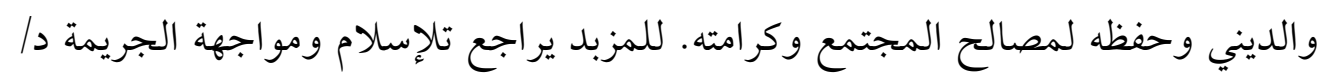

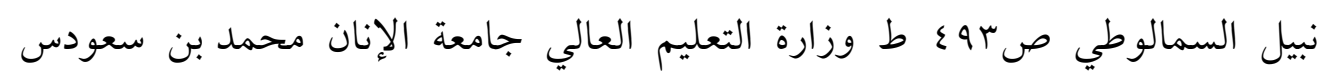


الصراع والدمار، وإذا اختل التوازن بين العلاقات الدولية تحدث الحروب

$$
\text { و الصراعات. (1) }
$$

وخلاصة القول: إن الحياة لاتستمر ولا تستقر بدون تحقيق هذه

الضروريات، وأن أي مجتمع تتحقق فيه هذه الضروريات فهو مجتمع أمن ومتوازن ومستقر، وأي مجتمع تغيب فيه هذه الضروريات فهو مجتمع يسوده الخوق والاضطر اب وتصعب فيه الحياة.

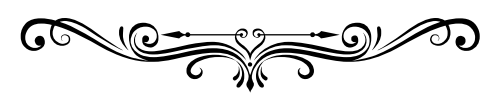

(1) وسطية الإسلام وسماحته - محمد الصالح (ص: جr، بترقيم الشاملة آليا) الناشر: الكتاب منشور على موقع وزارة الأوقاف السعودية بدون بيانات 


\section{المطلب الثاني}

\section{المقاصد العامة وتحقيق الاستقرار المجتمعي.}

المقاصد العامة للشريعة هي: القضايا الكلية التي تلاحظ في جميع أو أو التئ أغلب أبواب الشريعة، وجميع أحكام الشريعة تستهدف تحقيق مصالح

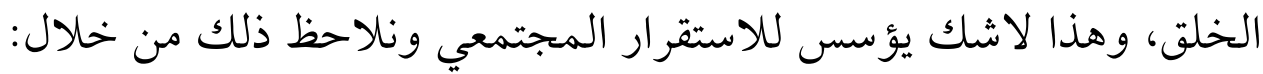
أولاً:مقصد جلب المصالح (1) ودرء المفاسد (1).

هذا المقصد مقصد عظيم تدور في فلكه أحكام الشريعة كلها، حيث

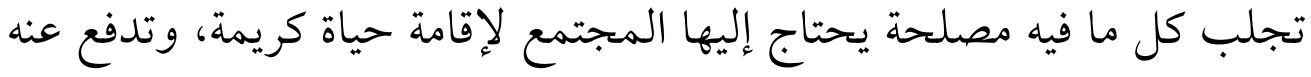

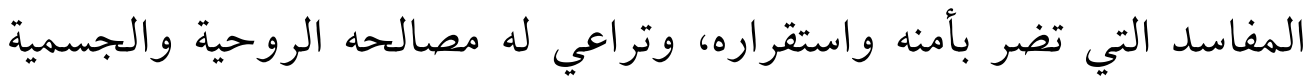
والنفسية، وكل هذا لا شك يهلف بأل إلى غاية عظيمة وهي: تحقيق مصالح

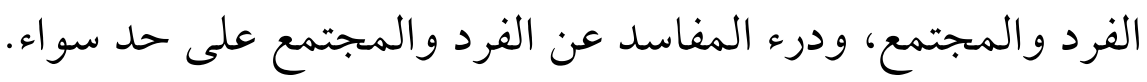

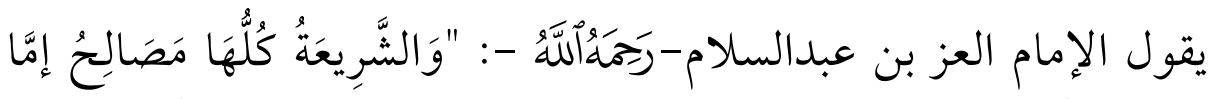

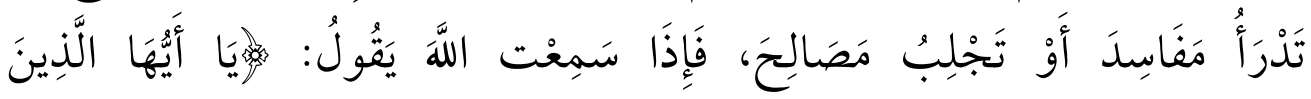

(1) جلب المصالح: وهي الأمور التي يحتاج إليها المجتمع لإقامة حياة الناس على أقوم

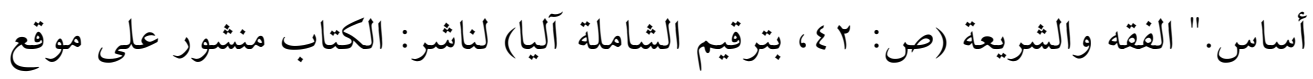
وزارة الأوقاف السعودية بدون بيانات

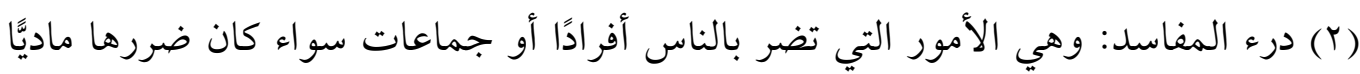
أو خلقيًّا. " الفقه والشريعة (ص: و أع، بترقيم الشاملة آليا) 


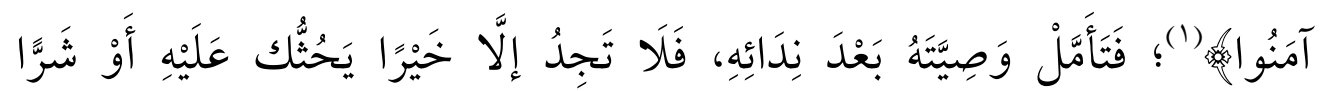

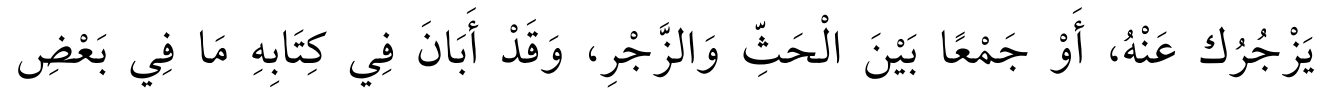

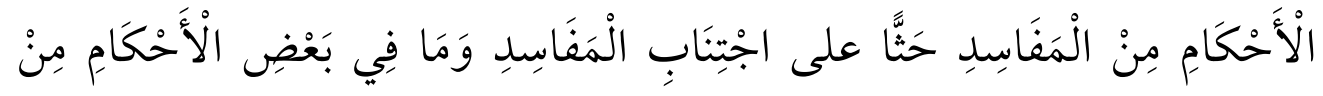

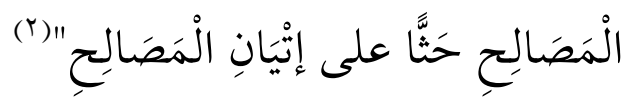

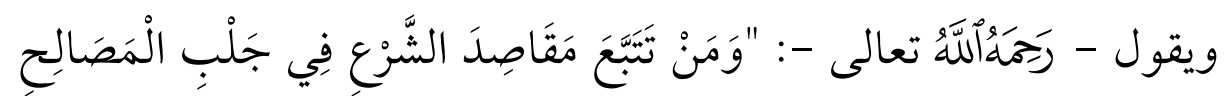

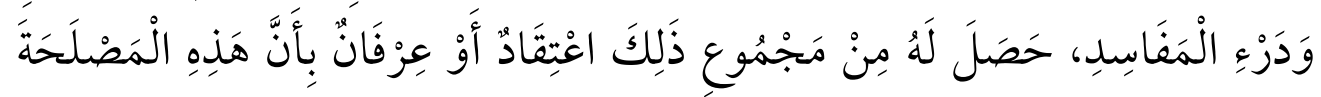

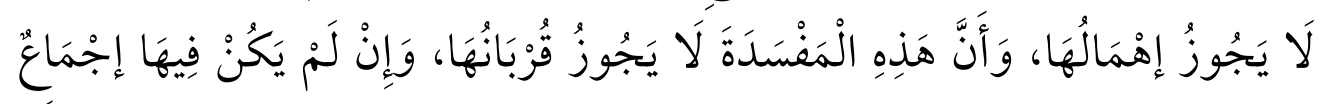

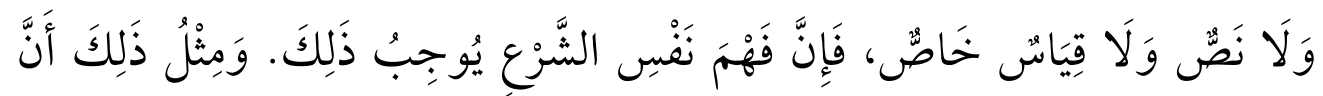

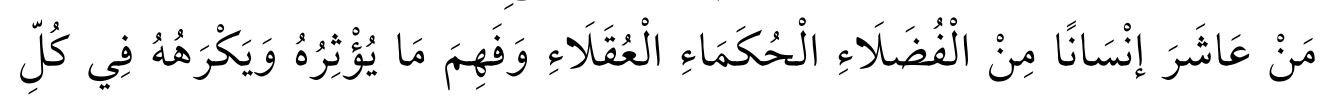

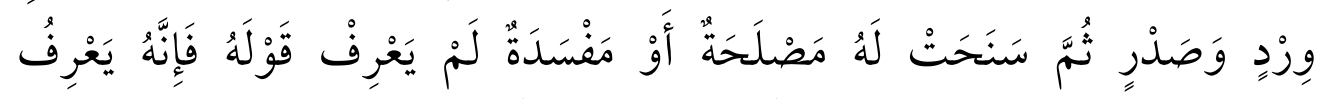

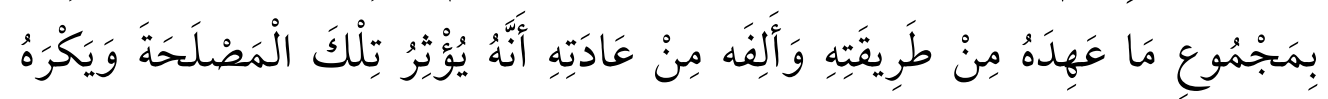

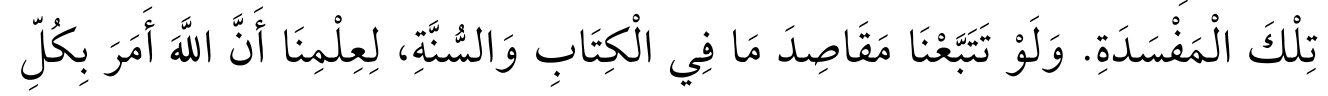

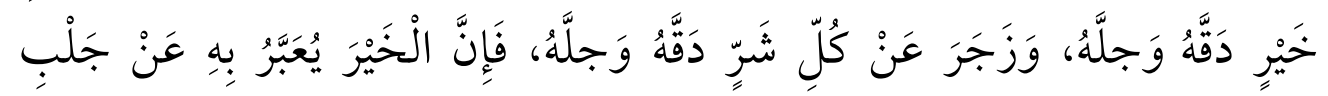

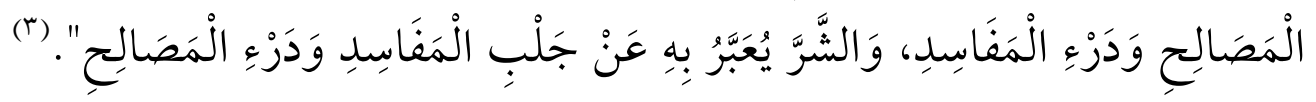

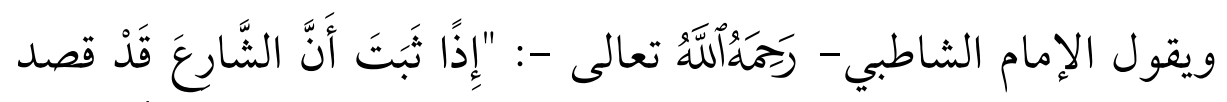

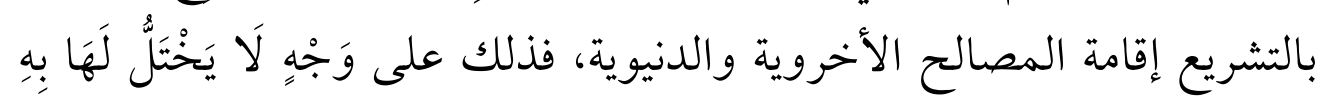

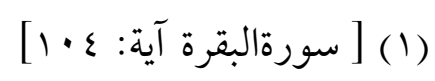

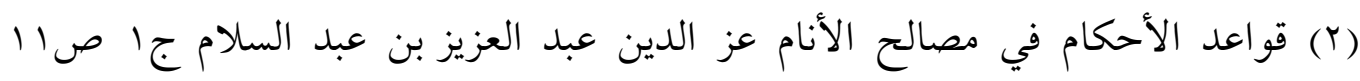

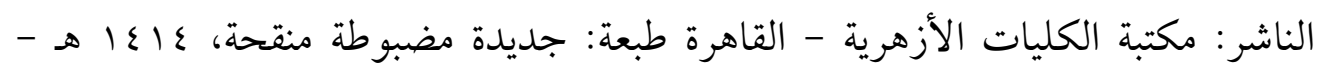
1991 199 مراجعه وعلق عليه: طه عبد الرؤوف سعد.

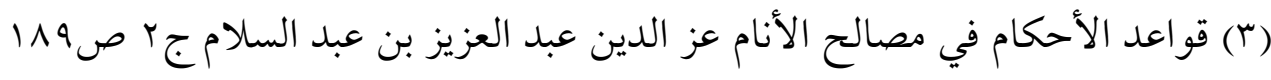




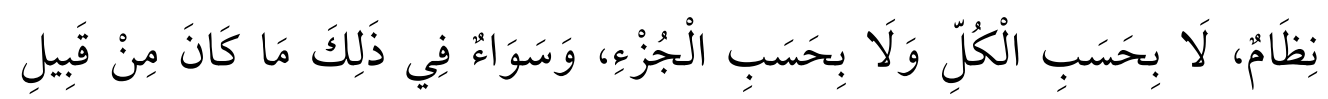

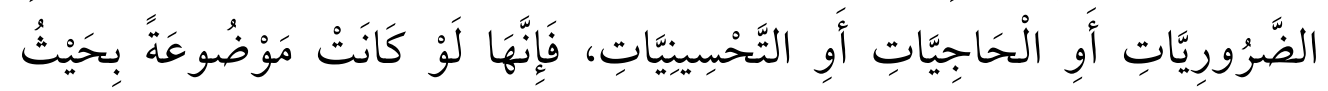

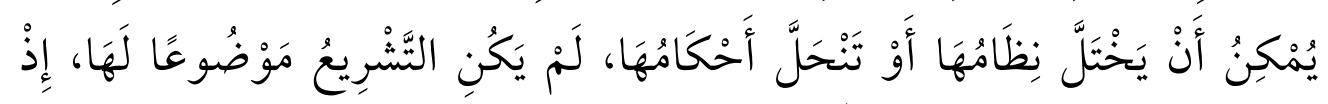

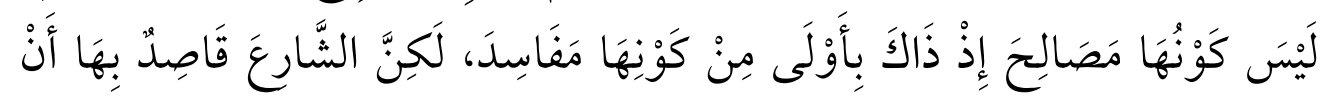

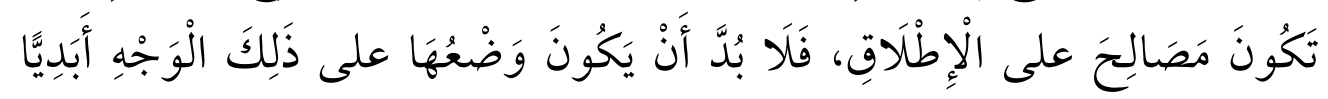

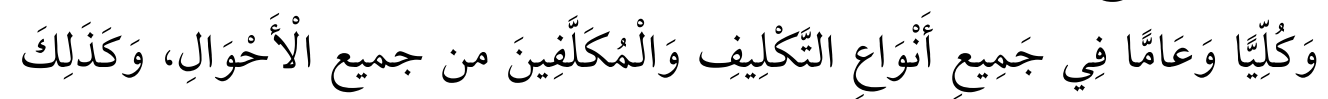

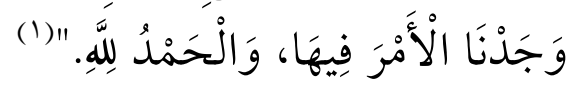

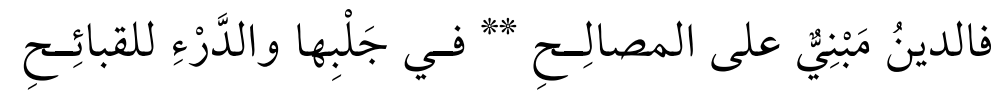

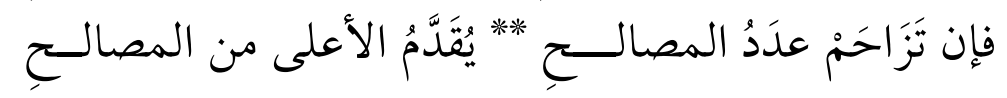

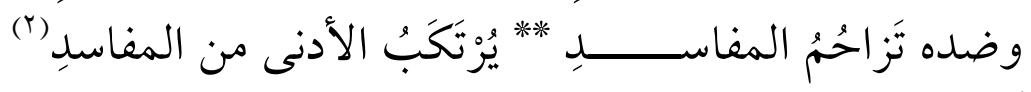

فما من خير إلا دعت إليه الشريعة ورغبت فيه، وما من شر إلا حذرت برت

منه ونهت عنه،

يقول الإمام العز بن عبدالسلام - رَمَهَهُألَّهُ -: "وَقد حث الرب سُبْحَانَهُ

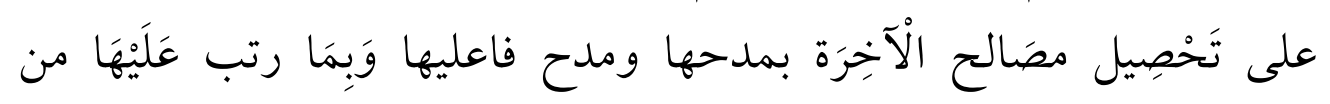

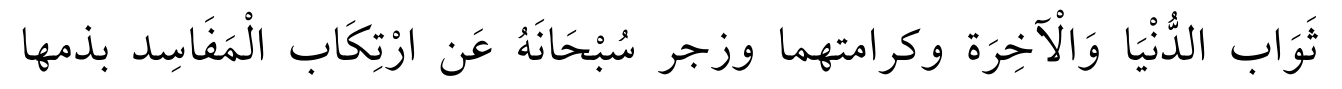

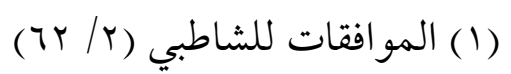

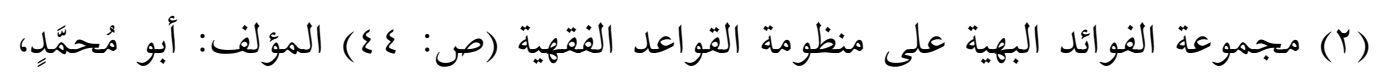

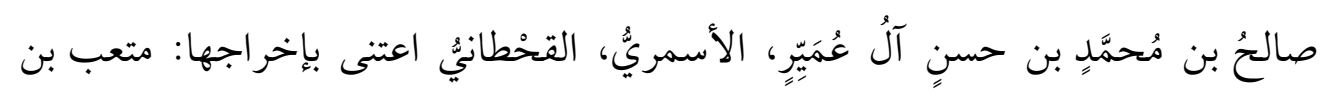

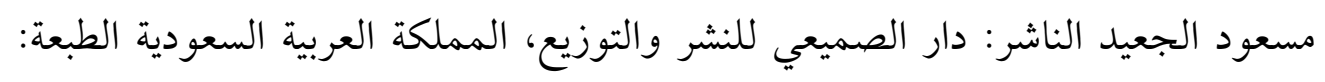

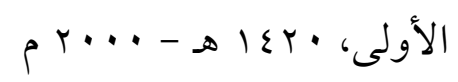




\section{وذم فاعليها وَبِمَا رتبه عَلَيْهَا من عِقَابَ اللُّنْيَا وَالْآخِرَة" (1)}

وبما أن الشريعة منهج حياة، فقد وضعت لذلك من التدابير الوقائية والعلاجية الجالبة لكل نافع، ودافعت كل ضار، سواء كان ذلك في الضروريات، أو الحاجيات، أوالتحسينيات، فالاستقرار الاجتماعي هو منظومة كبيرة تتكون من عدد من المنظومات الفرعية المتظافرة مثل: الاستقرار الاقتصادي، و الاستقرار السياسي، وجلب المصالح ودرء المفاسد مطرد في

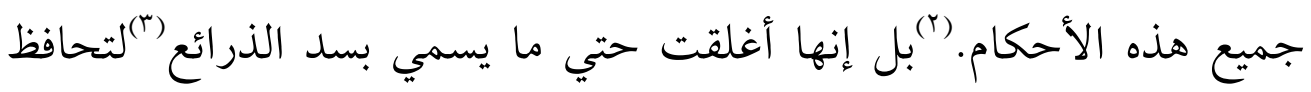
على الفرد والمجتمع من الإنحراف.

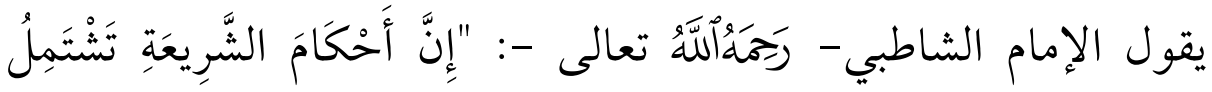

(1) الفوائد في اختصار المقاصد (ص: rV) المؤلف: أبو محمد عز الدين عبد العزيز بن عبد السلام بن أبي القاسم بن الحسن السلمي الدمشقي، الملقب بسلطان العلماء (المتوفى: • •7هـ) المحقق: إياد خالد الطباعالناشر: دار الفكر المعاصر، دار الفكر -

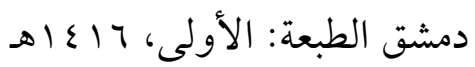
وللمزيد في معرفة هذا الاطراد في جميع الأحكام الشرعية المتعلقة بنواحي الحياةالاجتماعية منها والسياسية والاقتصادية يراجع: قواعد الأحكام في مصالح الأنام

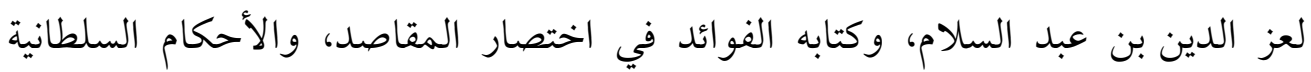

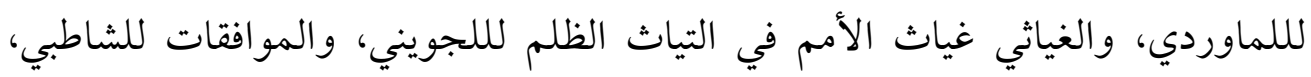
والسياسة الشرعية في الشئون الدستورية والخارجية والمالية لعبد الوهاب خلاف ولئ وغير ذلك.

وسد الذرائع: أي منع الطرق التي تؤدي إلى إهمال أوامر الشريعة أو الاحتيال عليها أو

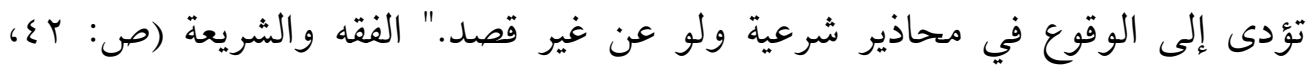
بترقيم الشاملة آليا) 


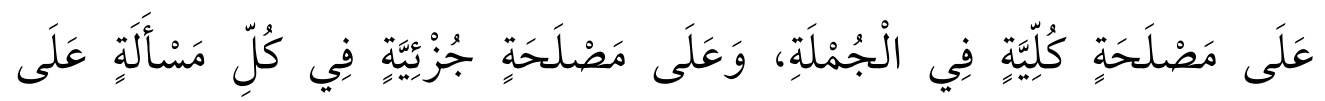

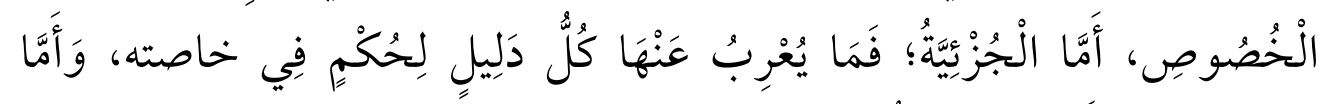

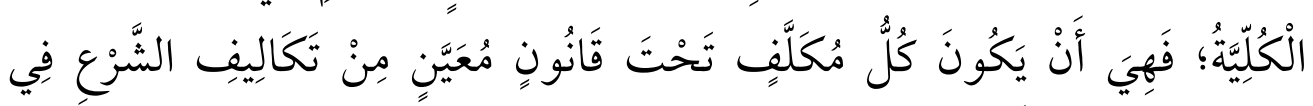

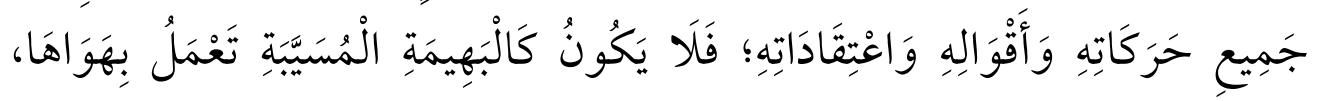

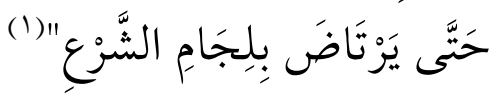

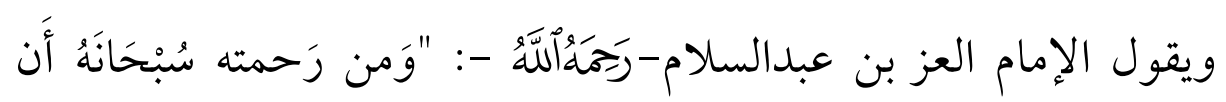

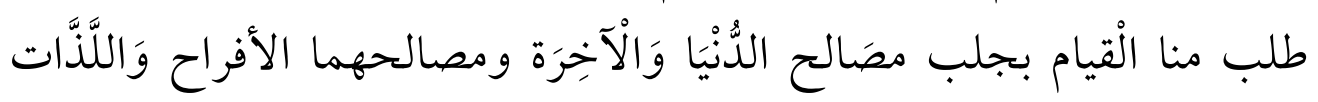

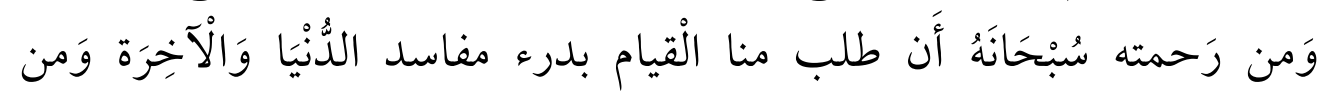

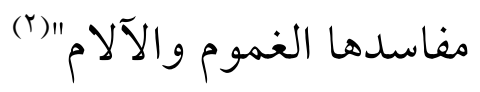

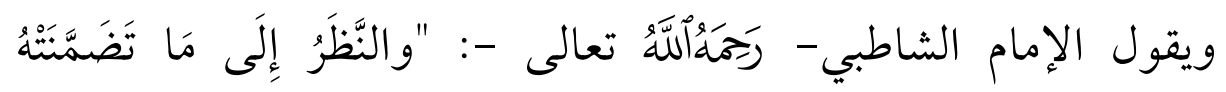

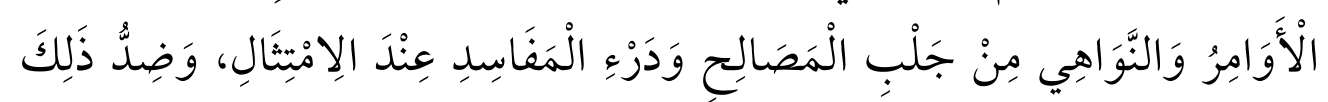

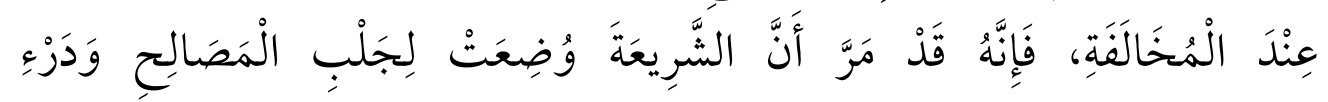

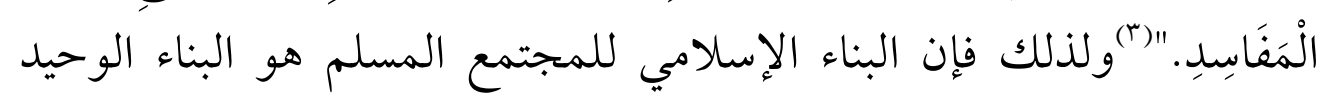

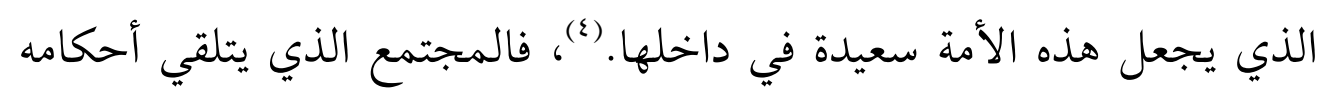

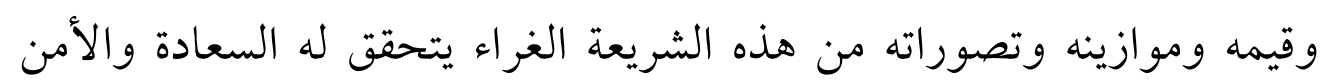

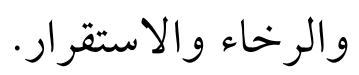

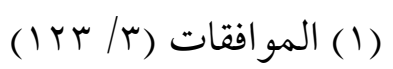

$$
\begin{aligned}
& \text { (r) الفوائد في اختصار المقاصد (ص: (T) ( or) }
\end{aligned}
$$

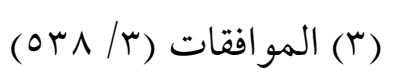

$$
\begin{aligned}
& \text { (ع) السلوك الإجتماعي في الإسلام حسن أيوب ص } 9 \text { (ابتصرف. }
\end{aligned}
$$


ثانياً:مقصد اليسر ورفع الحرج:

جاءت الشريعة الغراء لمراعاة حاجة المكلف وقدرته على امثثال الأمر واجتناب النهي، وبينت أن الحرج مرفوع ومدفوع فشرعت له اليسر ورفع الحرج، وجعلته مقصداً من مقاصدها.

ولا شك أن التيسير روح يسري في جسم الشريعة كلها، وهو مبني على رعاية ضعف الإنسان، والله هو الذي خلقه ولا يريد به عنتا، إنما يريد له

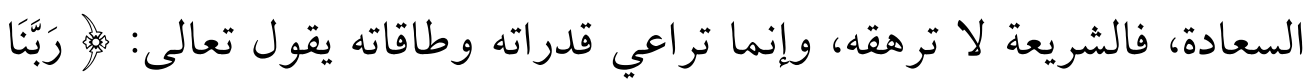

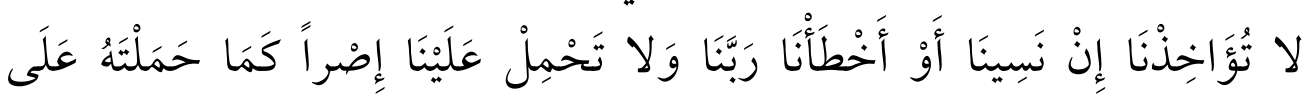

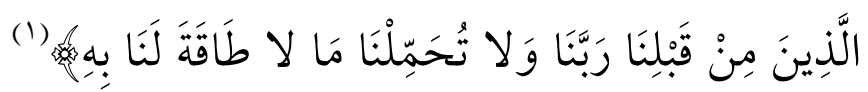

يقول الإمام الرازي- رَمَمَهُأنَّهُه- في المحصول: " فلو شرع ما لا يكون للعبد فيه مصلحة لم يكن ذلك رأفة ولا رحمة و انه تعالى ما شرع الأحكام (إلا لمصلحة العباد."

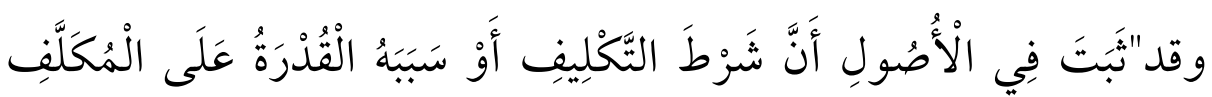

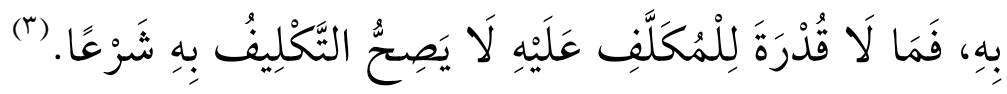

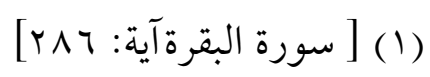

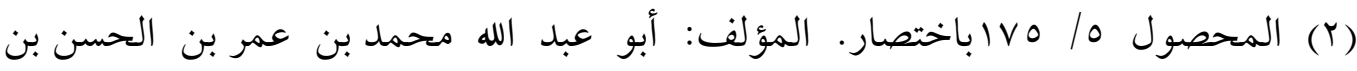

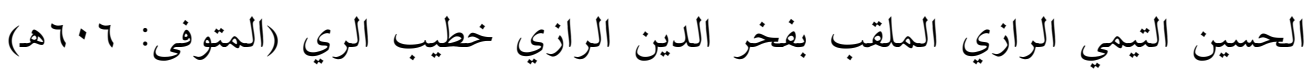

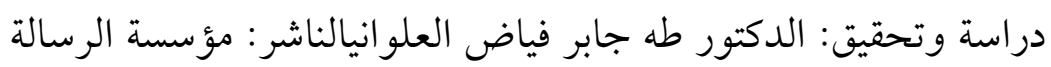

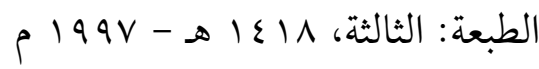

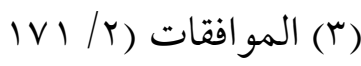


وهناك مظاهر لليسر ورفع الحرج كثيرة، حيث شملت كل أحكام

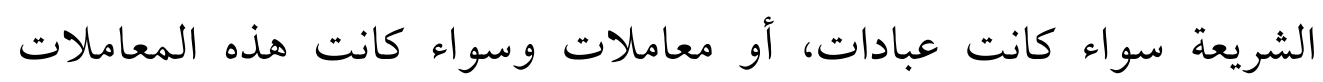

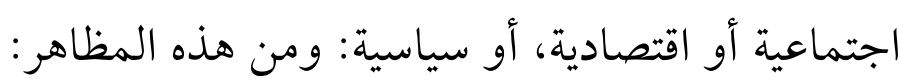

(أ) أن الله وضع عن الأمة الإصر والأغلال التي كانت على الأمم السابقة. يقول الإمام ابن كثير - رَحَمَاُلْلَّهُ:- " إنّ النبّيّ جاء بالتّيسير والسّماحة.

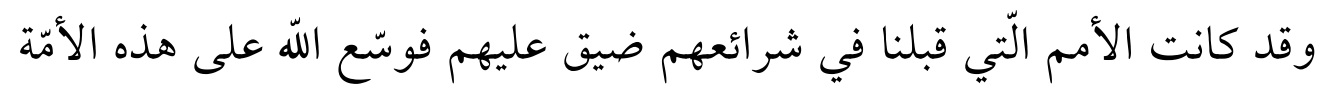

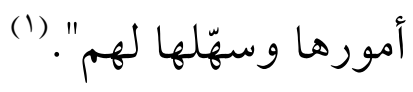
(ب) مراعاة جانب الرخص.

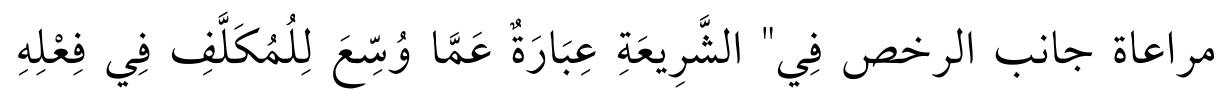

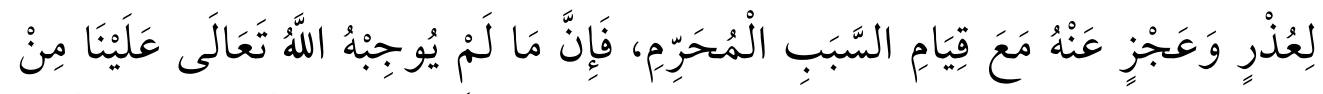

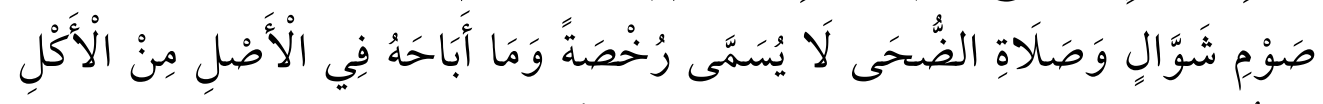

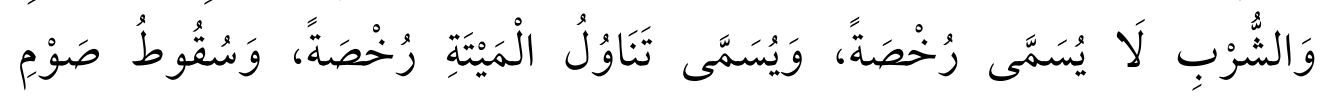

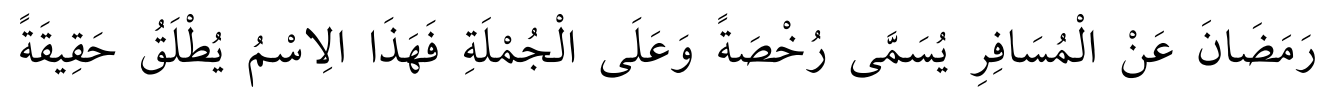

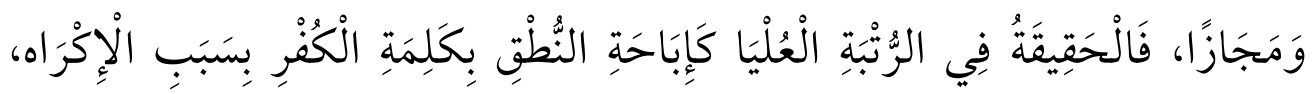

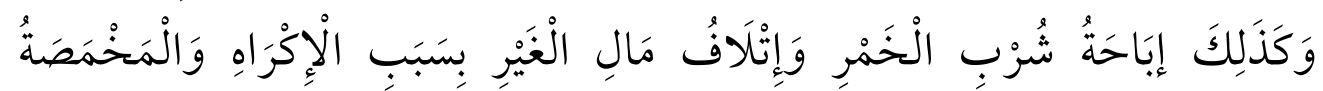

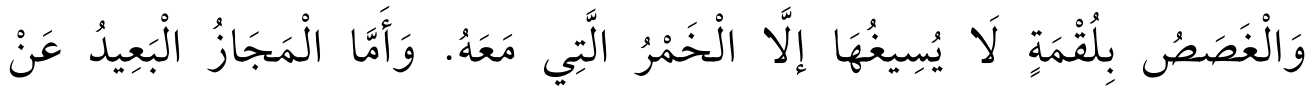

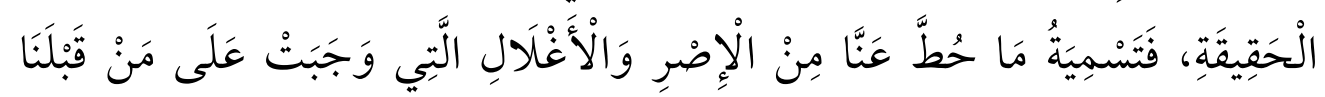

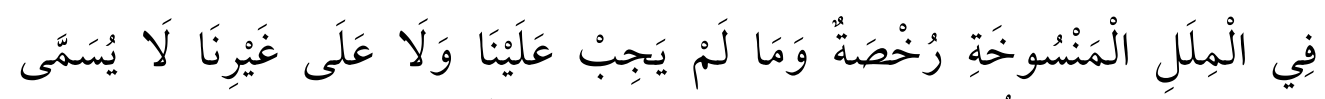

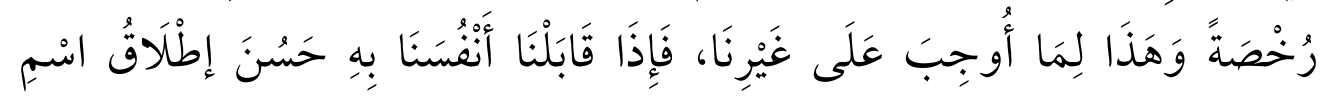

(1) تفسير القر آن العظيم: الإمام ابن كثير (r/ ؟ ؟ ) 


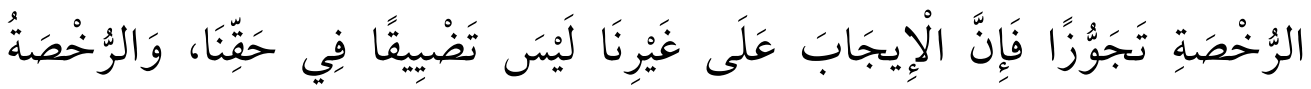

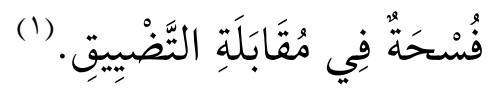
و الرخص منح من الله تعالى وعطايا لعبادة، ولها أنواع منها كما قالَ

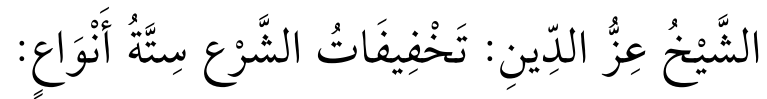

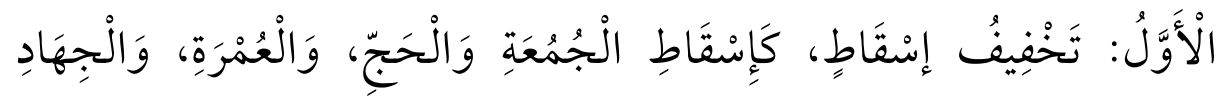
بالألَعْذَارِ الثَّانِي: تَخْفِيفُ تَنْقِيصِ، كَالْقَصْرِ .

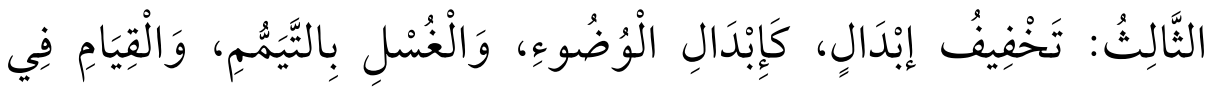

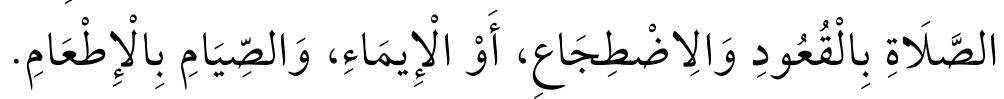

الوَّابعُ: تَخْفِيفُ تَقْدِيمٍ، كَالْجَمْعِ، وَتَقْدِيمِ الزَّكَاةٍ على الْحَوْلِ، وَزَكَاةِ

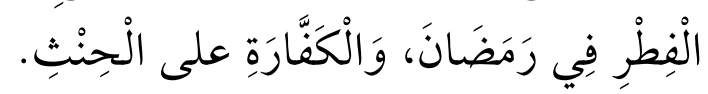

الْخَامِسُ: تَخْفِفُ تَأْخِير، كَالْجَمْعَ في الصلاة جمع تأخير أو تقديم،

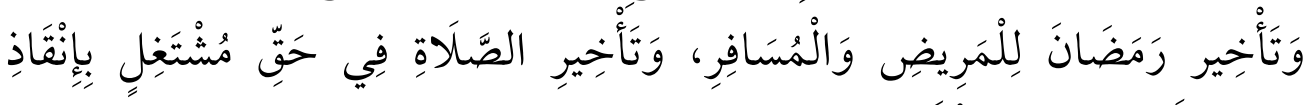

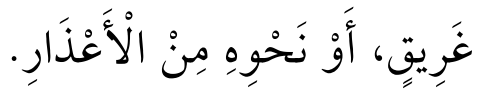

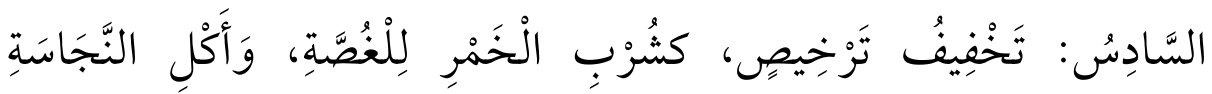

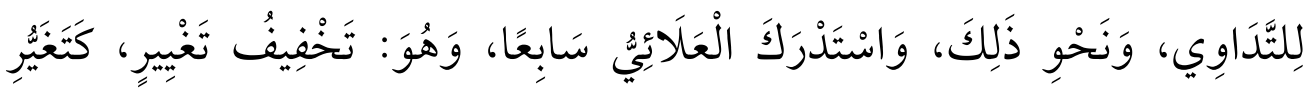

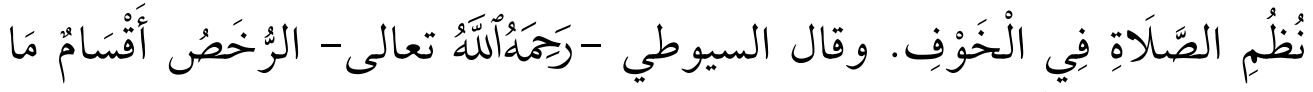

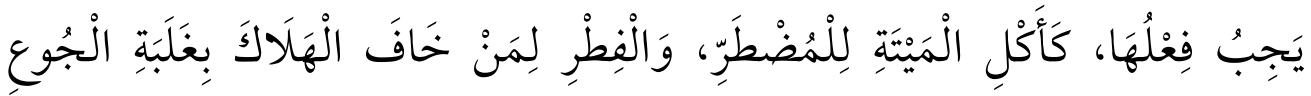




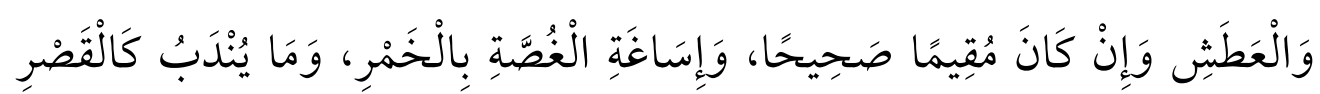

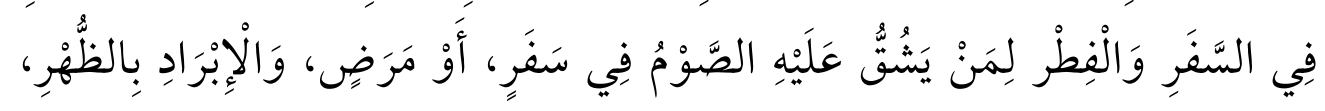

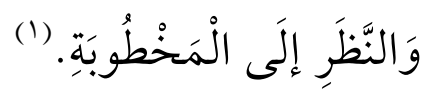

ومما يدخل في معنى التيسير الرجوع إلى القواعد الشرعية التي أصلها

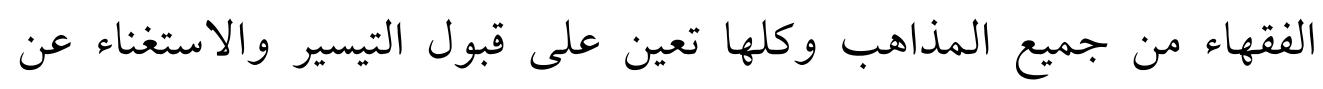
الإعنات والتعسير، ومن هذه القواعد:

$$
\text { (أ) الضرورات تبيح المحظورات. }
$$

(ب) (ب) المشقة تجلب (1)

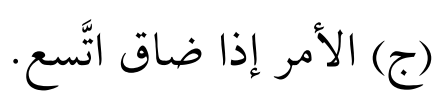

$$
\text { (د) الضرورات تَقَدَّر بقَْْرِها }
$$

(هـ) الحاجة تُنَّل منزلة الضرورة، عامة كانت أو خاصة.وغير ذلك من

$$
\text { القواعد التي تحمل التيسير }
$$

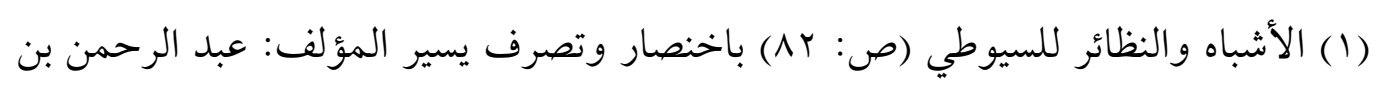

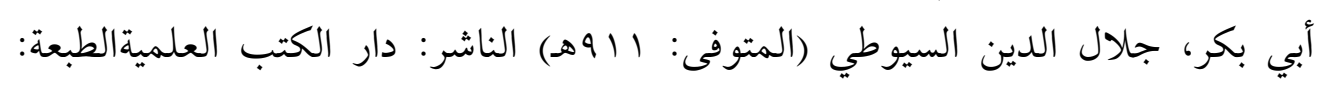

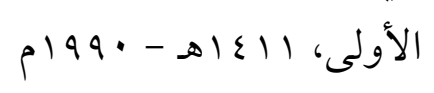

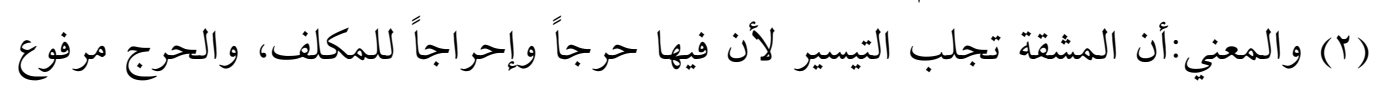

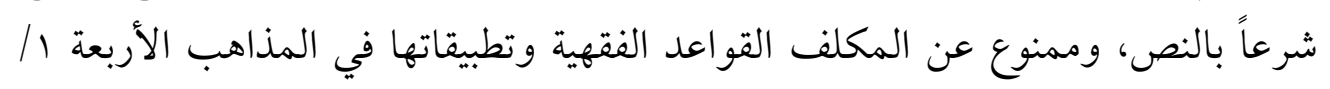

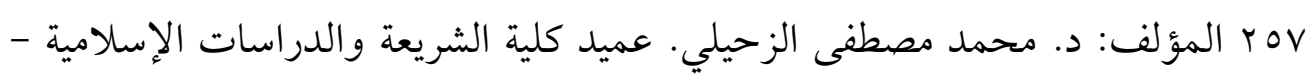

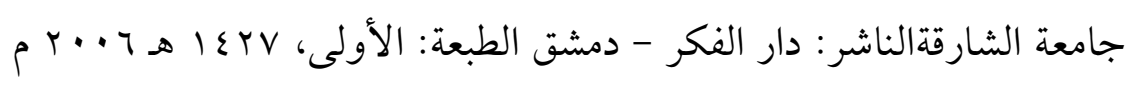


وبعد هذا العرض للمقاصد العامة نسطتيع أن نحدد المحور الرئيس

$$
\text { التي تدور حوله وهو: }
$$

أ- جلب المنافع ودرء المغاسد.

خدم هذا المقصد الاستقرار في أنه: لا يخلو أمر من أوامر الله إلا وفيه

خير ونفع وسواءً عُلمت هذه الحكمة أو لم تُعْلَم، وكذلك لا يخلو نهي إلا وفيه مفسدة سواءً عُلمت هذه الحكمة أو لم تُعْلَم، ولذلك نجد أن كل مايخدم ويرسخ الاستقرار المجتمعي أمرت به الشريعة وكل ما يعكره نهت عنه.

ومثال الأمر: أنها أمرت: بالعلم،والعمل،وبالعدل، والإحسان، والصدق والأمانة، والصبر والوفاء، والحياء والعفاف، والسخاء والشجاعة، والمروءة والنجدة، والقصد والاعتدال، والسماحة والحلم، وكل خصال الخير. ومثال النهي: فقد نهت عن كل ما فيه مفسدة مثل:الجهل وشرب الخمر، والزنى، والربا، وأكل أموال الناس بالباطل، وقطيعة الأرحام، والإساءة إلى الجار، وإيذاء الآخرين، و الكذب والخيانة والغدر والفجور وكل رذيلة.

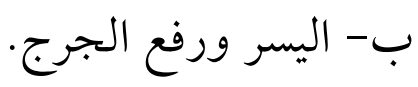
خدم هذا المقصد الاستقرارحيث: تيسير التعامل بين الناس في جميع نواحي الحياة، والرفق بهم وإرشادهم إلى التراحم والتيسير فيما بينهم مع عدم الإخلال بالو اجبات والحقوق. 


\section{الخاتممة}

وتشتمل على: نتائج البحث وتوصياته.

\section{أولاً : نتائج البحث.}

وبعد الانتهاء من هذه الدراسة، أحببت أن أدون بعض النتائج التي

$$
\text { تمخضت عنها فكانت كما يلي: }
$$

1- الاستقرارالمجتمعي يعني: حالة من السكينة والطُّمَأْينَة والانتظام والتعايش بين أفراد المجتمع على وجةٍ يتسق مع سنن الله ومنهجه.

ץ- الاستقرار المجتمعي يعني: التعايش مع جميع الأشخاص المشتركين في الوطن الواحد، وحماية النسيج المجتمعي من كل الآفات المادية

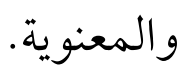

r- الاستقرارالمجتمعي يعني: غياب كل مظاهر العنف والعداوة والبغضاء والكراهية والتناحر والتقاتل وتوفير الوئام والسلام.

ع - الاستقرارالمجتمعي تقوم عليه الحياة ويحقق الخيرللناس والسعادة، وحفظه وصيانته واجب على الجميع، وتضيعه فيه الخسران المبين والعيشة الضنك.

ه- الاستقرار به قوام حياة المجتمع وقد فشلت مجتمعات كثيرة في إيجاده وتحقيقه وحمايتة بسسب أنها لم تحقق مقوماته، وها هي اليوم تعج بألو ان من القلق، والتفكك والاضطر اب، و الصارع و التقاتل. 
ع-من مقومات الاستقرارالمجتمعي: تحقيق الإيمان، والأخوة والترابط،

والعدل، و التعايش، و والوسطية، ومن العوامل الهادمة للاستقرار المجتمعي، ضياع الإيمان، والتعصب والفرقة، والطائقية والمذهيبة، و الظلم وضياع الحقوق، والغلو والتطرف.

7- الشريعه بمقاصدها هي التي استطاعم أن تحقق الاستقرار على الوجه الصحيح، حيث وضعت من الأجراءات والتدابير الوقائية والعلاجية

$$
\text { لنشره وترسيخه وحر استه. }
$$

- حرصت الشريعة بمقاصدها على بناء الفرد والأسرة بناء عقدياً،

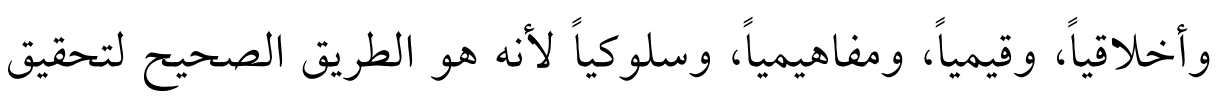

$$
\text { الاستقرار }
$$

1- إذا فُقِد الاستقرار اختلّ نظام الحياة، وتعرَّ الناس للخطر والدمار و الضياع والانهيار الشامل في جميع نواحي الحياة.

ه- الاستقرار له دور هام في النهوض بالأنسانية ورقيها؛ ويعمل على إيجاد مجتمع فاضل قوي.

\section{ثانياً - أهم التوصيات.}

وفي الختام: إن كان هناك من توصيات ومقترحات في هذا الصدد

$$
\text { فإنها تكمن في: }
$$

1- بذل الجهود العلمية وتوسيع البحث في موضوع الاستقرار المجتمعي من الناحية الشرعية المقاصدية. 
r- إنشاء مراكز ومواقع علمية شرعية متخصصة تبحث فى كيفية النهوض

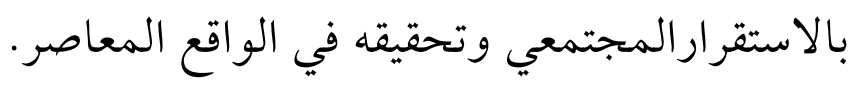

r- إقامة دورات علمية متخصصة للأئمة والدعاة إلى الله فى كيفية نشر قيمة

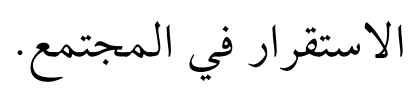

ع- تفعيل ثقافة الاستقرار حيث إنه لم يأخذ مجاله بعد، وذلك من خلال:

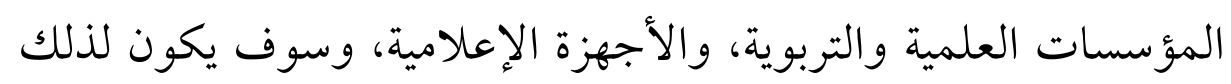
من الآثار الحضارية على البشرية جمعاء.

ه- عقد ندوات ومؤتمرات علمية وورش عمل لمناقشة تفعيل دور العلماء

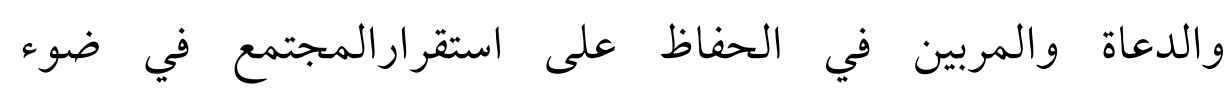
المستجدات والوقائع. ولهي.

r- تفعيل دور مؤسسات الدولة نحو الوصول إلى تحقيق مقومات

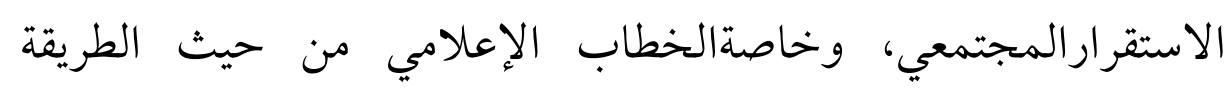

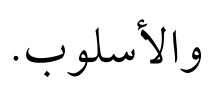

V- العمل علي الوصول بالمجتمع إلي التمبيز بين الخير والشر، والصحيح

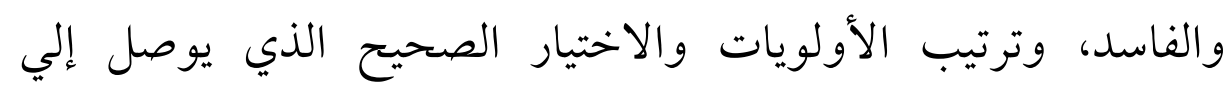

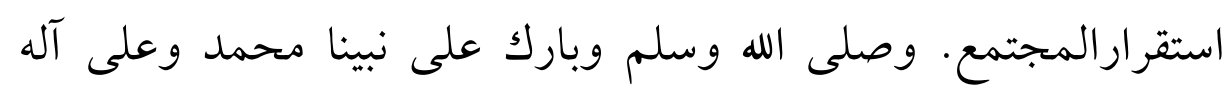
وصحبه أجمعين.

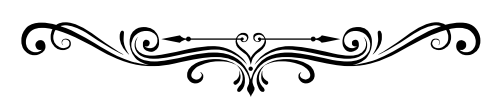




\section{المصادر والمراجع العامة}

أو لا: القران الكريم ... سبحان من أنزله. ثانياً: أهم المصادر والمراجع مرتبة التريم تريباً أبجدياً:

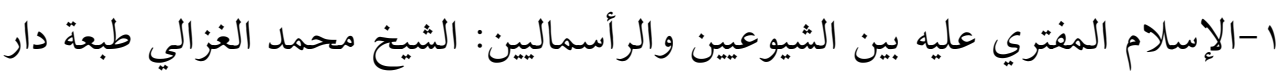
نهضة مصر الطبعة الأولي. r-الإسلام عقيدة وشريعة: الإمام الأكبر الشيخ محمود شلتوت ص طبعة دار البعة الشروق،

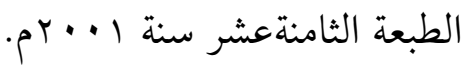
r- الإسلام وبناء الشخصية: الدكتور احمد عمر هاشم طبعة دار المنار للنشر والتوزيع

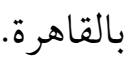
ع-الأشباه والنظائر المؤلف: عبد الرحمن بن أبي بكر، جلال الدين السيوطي (المتوفى:

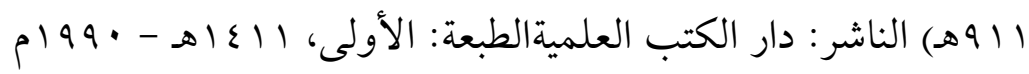

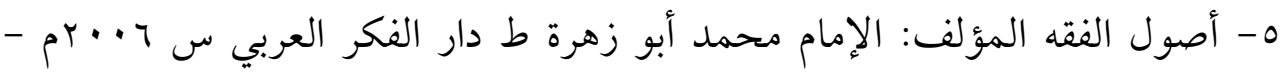
هI \&YV

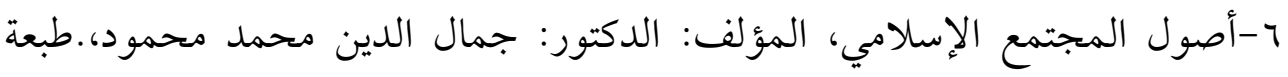

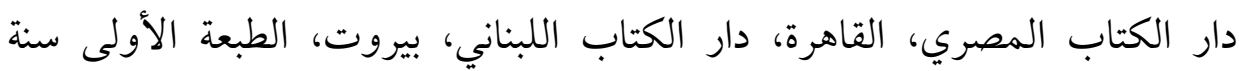

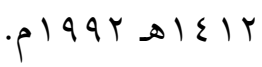

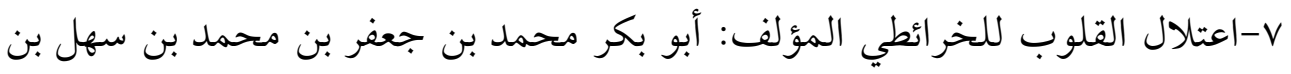

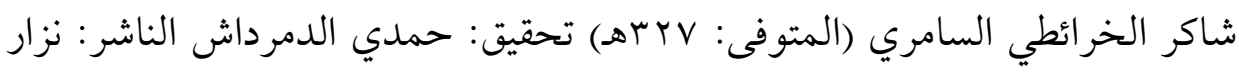

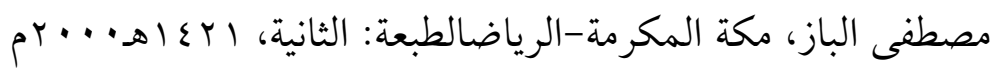

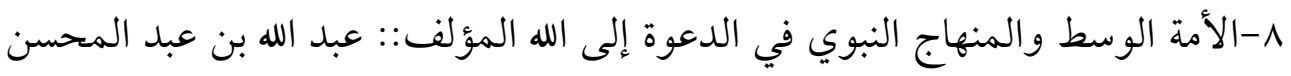

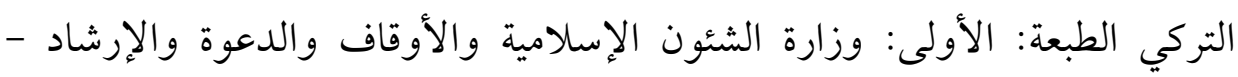

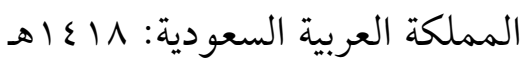
ه-تاريخ الطبري، المؤلف: محمد بن جرير بن يزيد بن كثير به بن غالب الآملي، أبو 
جعفر الطبري (المتوفى: ·لآهـ) (صلة تاريخ الطبري لعريب بن سعد القرطبي،

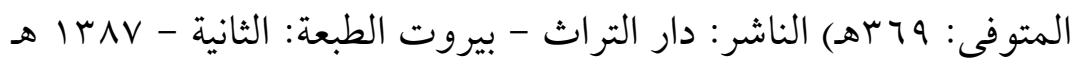

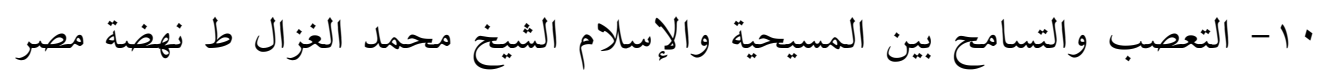

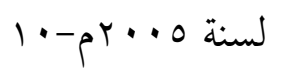

1ا-تفسير الشعراوي - الخواطرالمؤلف: محمد متولي الشعراوي (المتوفى: 11ـأهـ)

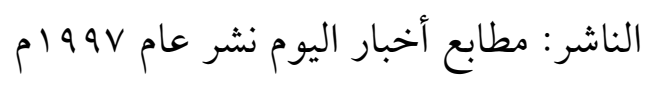

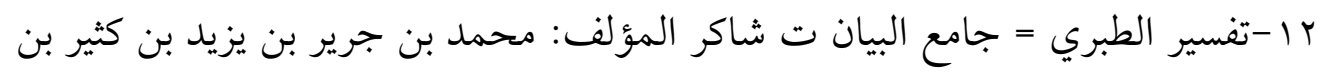

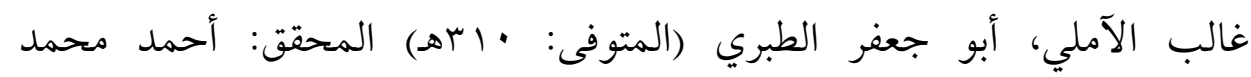

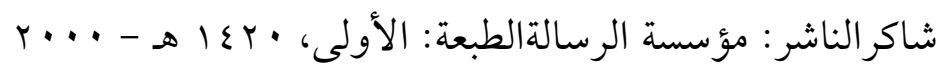

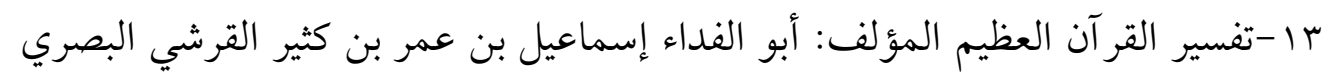

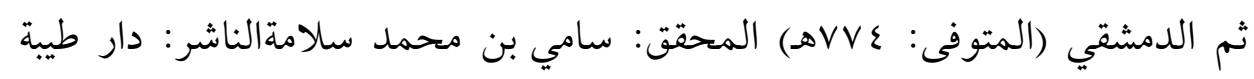

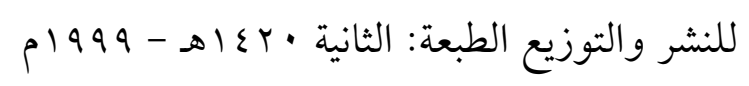

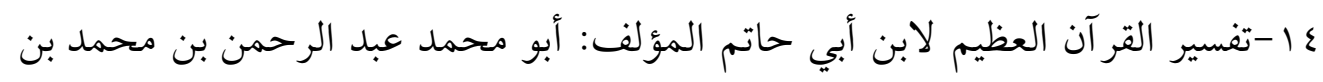

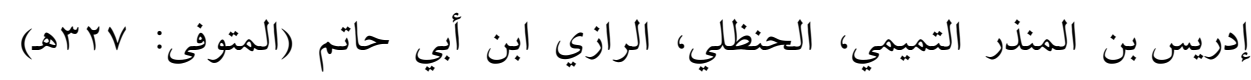

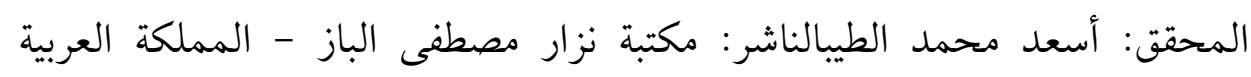

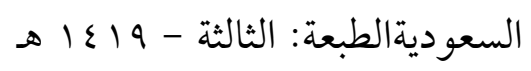

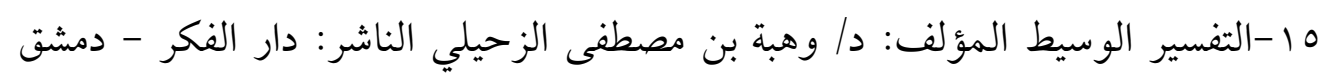

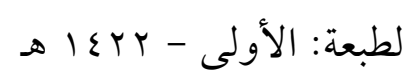

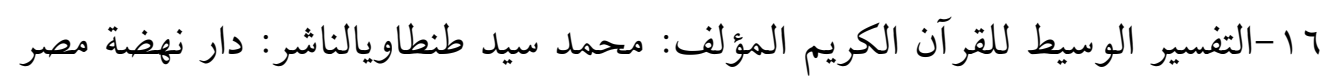

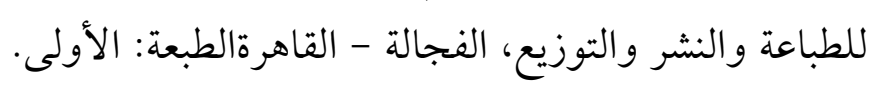

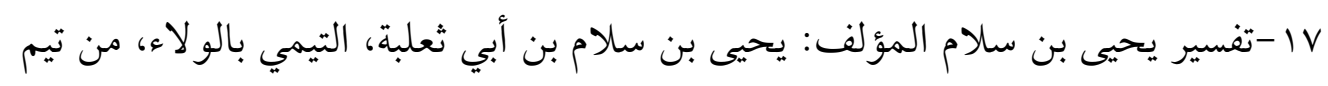

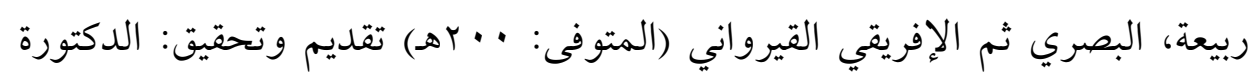

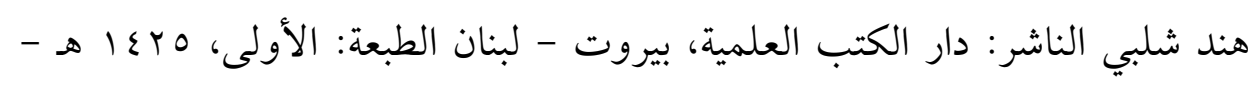


11-تنظيم الإسلام للمجتمع الشيخ /محمد أبو زهرة ص191 باختصار وتصرف ط

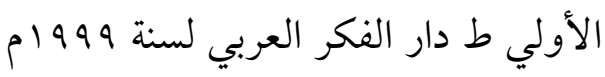

19 من تأثيرها في سائر الأمم المؤلف: عبد الرحمن بن حسن حَبنَّنَّكَة الميداني

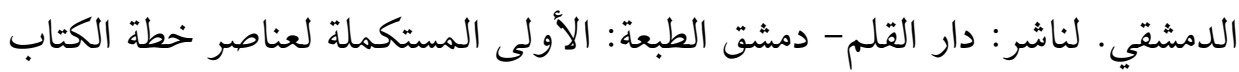

$$
\text { | } 991-81 \varepsilon 11
$$

• ץ-حضارة العرب:د. غوستاف لوبون، نقلة الى العربية الاستاذ: عادل زعتر، طبعة دار

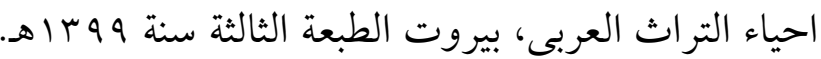

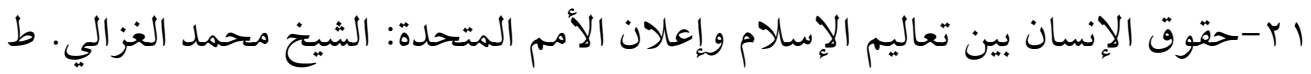
نهضة مصر ب-د.

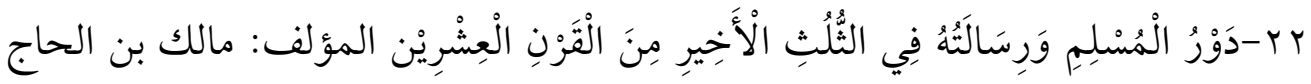

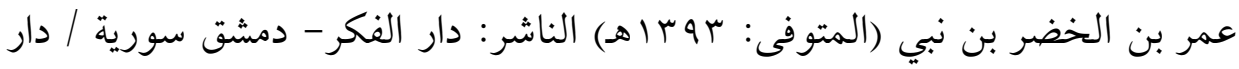

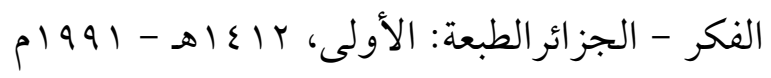

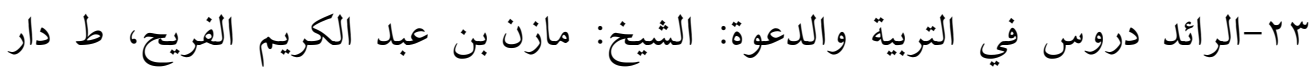

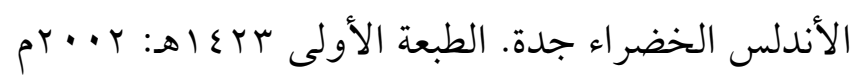

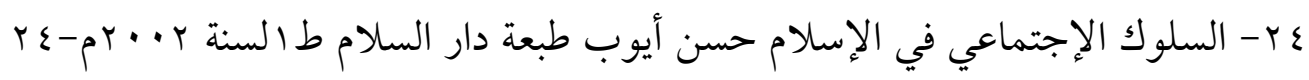

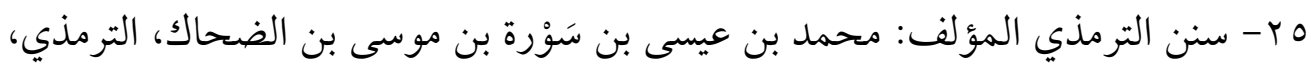

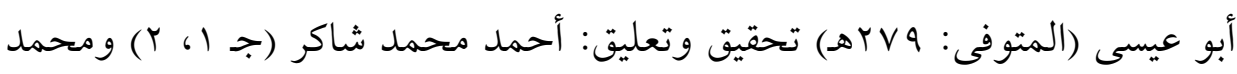

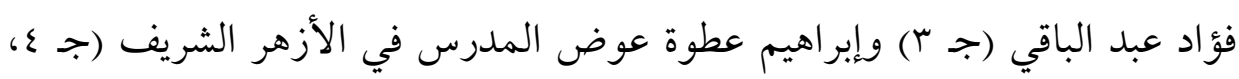
0) الناشر: شركة مكتبة ومطبعة مصطفى البابي الحلبي - مصرالبر الطبعة: الثانية،

$$
\text { م 19V0-ه1r90 }
$$

جr-السيرة النبوية عرض وقائع وتحليل أحداث: للدكتور علي محمد الصلابي طبعة

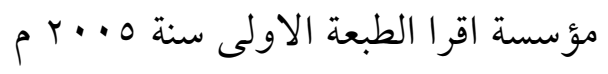

VY-السيرة النبوية لابن هشام المؤلف: عبد الملك بن هشام بن أيوبن الحميري 
المعافري، أبو محمد، جمال الدين (المتوفى: بآهـ) تحقيق: مصطفى السقا وإبراهيم الأبياري وعبد الحفيظ الشلبي الناشر: شركة مكتبة ومطبعة مصطفى البابي

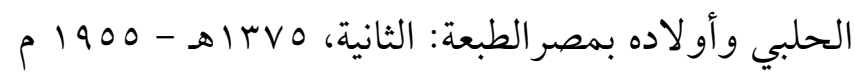

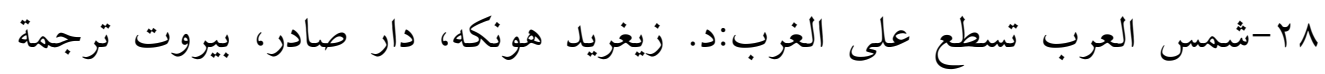

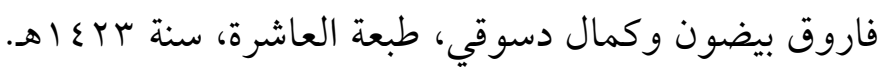

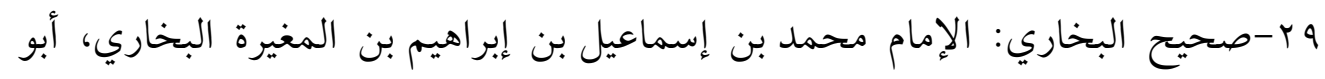
عبد الله المحقق: محمد زهير بن ناصر الناصر الناشر: دار طوق النجاة، الطبعة:

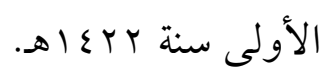

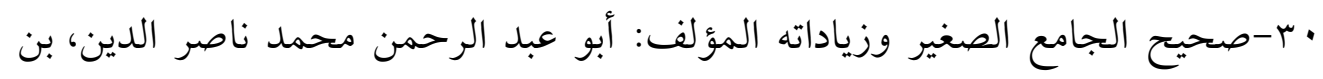
الحاج نوح بن نجاتي بن آدم، الأشقودري الألباني (المتوفى: · بعأهـ) الناشر: المكتب الإسلامي.

اب-صحيح مسلم: الإمام مسلم بن الحجاج أبو الحسين القشيري النيسابوري تحقيق:

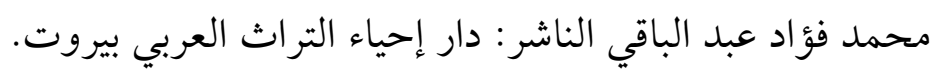

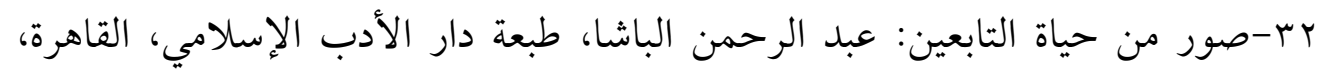

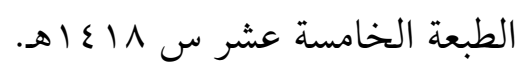
rr-طابع الإسلام بين الأديان: الأستاذ أنور الجندى. طبعة دار الأنصار، طبعة الأولى

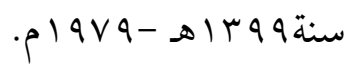
ع ז-علم المقاصد الشرعية المؤلف: نور الدين بن مختار الخادميالناشر: مكتبة العبيكان

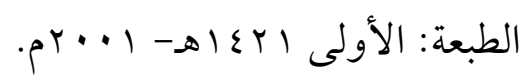

هr-غرائب التفسير وعجائب التأويل المؤلف: محمود بن حمزة بن نصر، أبو القاسم

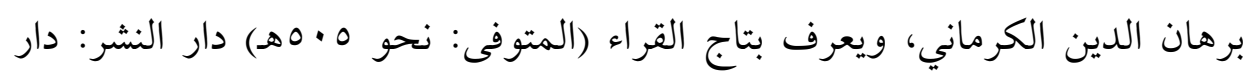

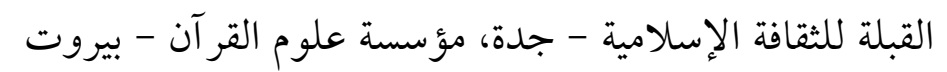

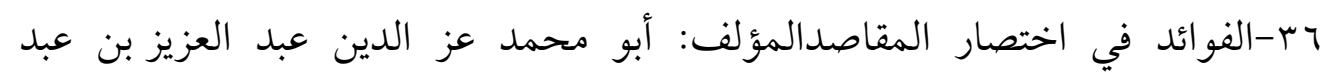
السلام بن أبي القاسم بن الحسن السلمي الدمشقي، الملقب بسلطان العلماء 
(المتوفى: • •7هـ) المحقق: إياد خالد الطباع الناشر: دار الفكر المعاصر، دار الفكر

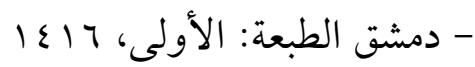
V V-القاموس الألفبائي يحيى بن الحاج الجيلاني وآخرون، طبعة الأهلية للنشر، بيروت:

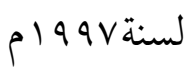

^ץ-القاموس الفقهي المؤلف: الدكتور سعدي أبو حبيب الناشر: دار الفكر. دمشق -

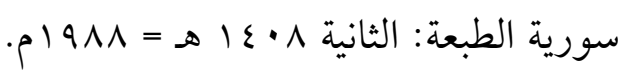
ه r-قواعد الأحكام في مصالح الأنام عز الدين عبد العزيز بن عبد السلام الناشر: مكتبة

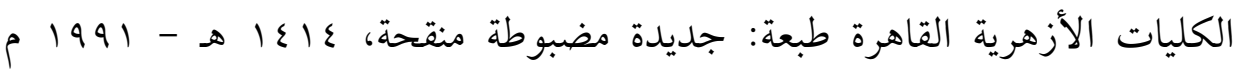
راجعه وعلق عليه: طه عبد الرؤوف سعد.

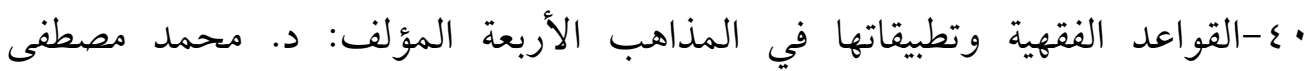

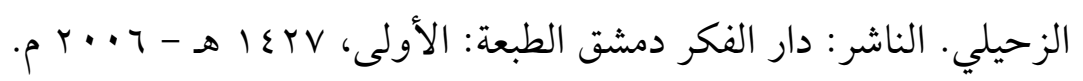

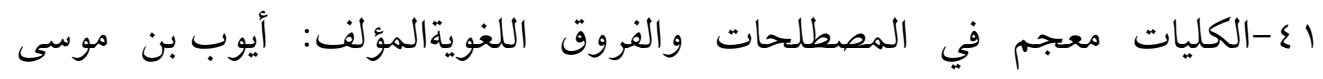

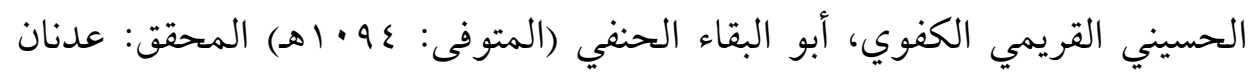

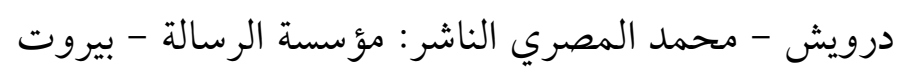

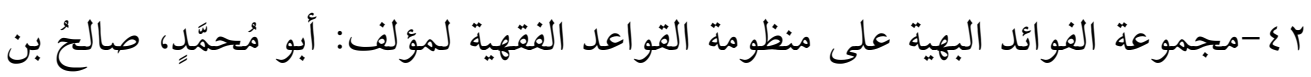

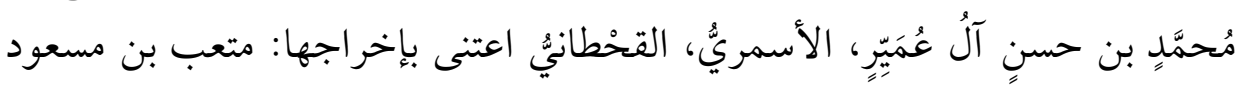

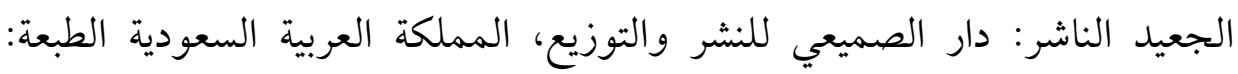

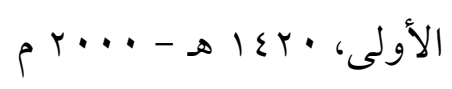

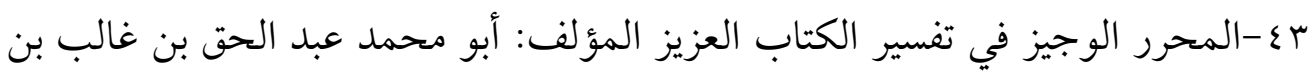

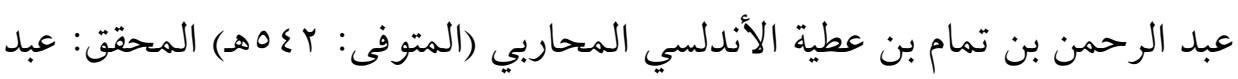

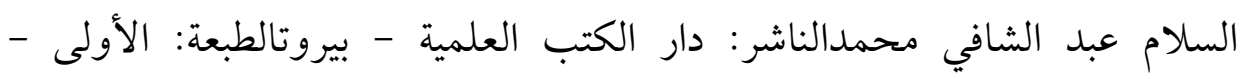
ه

ع -المحصول المؤلف: أبو عبد الله محمد بن عمر بن الحسن بن الحسين التيمي

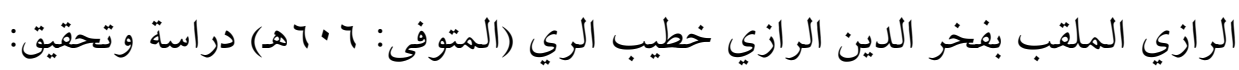


الدكتور طه جابر فياض العلواني الناشر: مؤسسة الرسالةالطبعة: الثالثة، 11 1 هـ $.0199 \mathrm{~V}$

هـ-المحكم والمحيط الأعظم المؤلف: أبو الحسن علي بن إسماعيل بن سيده المرسي

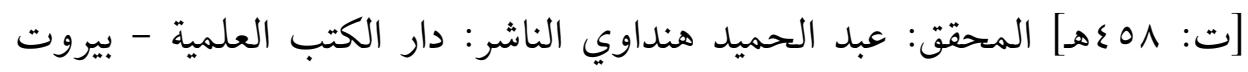

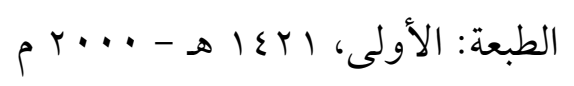

جع-مختار الصحاح المؤلف: زين الدين أبو عبد الله محمد بن أبي بكر بن عبد القادر

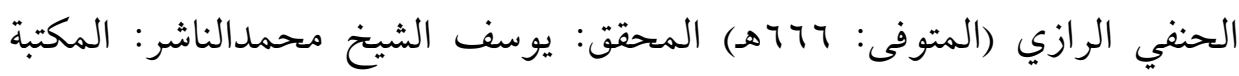

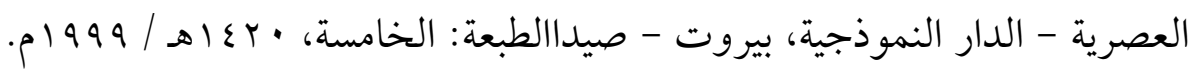

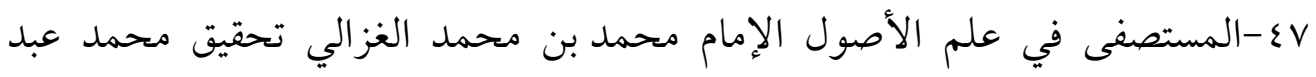

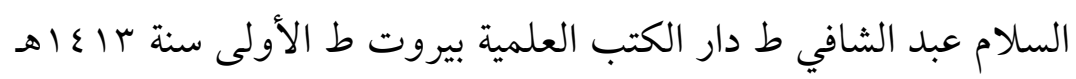

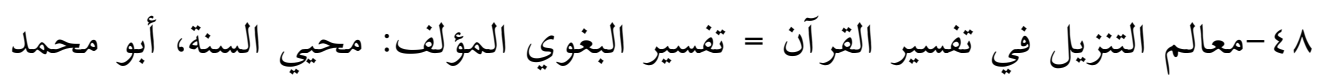

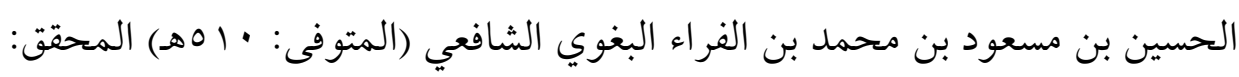

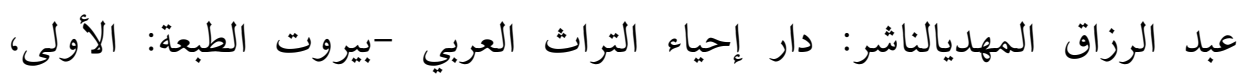
$ه 1 \leqslant Y$.

هـ-المعجم الوسيط المؤلف: مجمع اللغة العربية بالقاهرة (إبراهيم مصطفى / أحمد

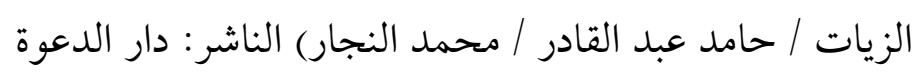

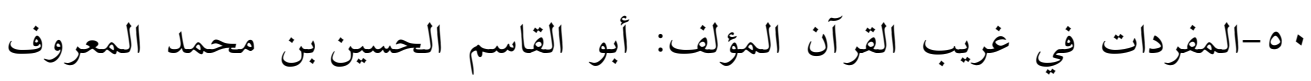

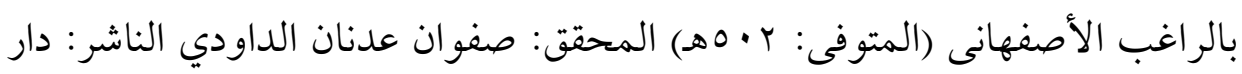

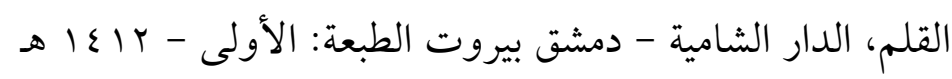

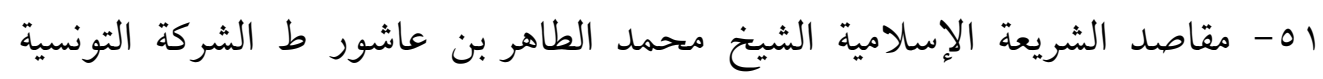

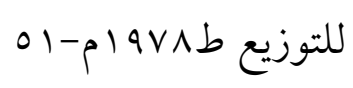

ro-الملل والنحل للشهرستاني محمد عبد الكريم، تحقيق عبد العزيز محمد الوكيل،

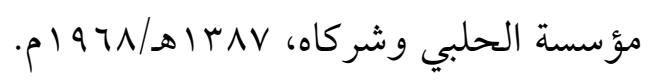

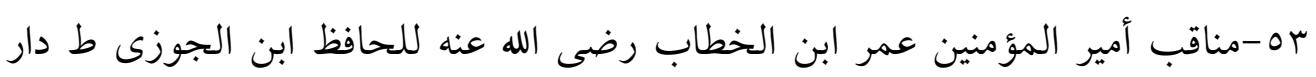


الكتب العلمية بيروت بدون الطبعة وسنة الطبع تحقيق د/زينب إبراهيم القاروط

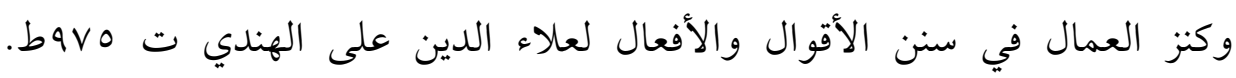
مؤسسة الرسالة. ع ه-الموافقات المؤلف: إبراهيم بن موسى بن محمد اللخمي الغرناطي الشهير بالشاطبي

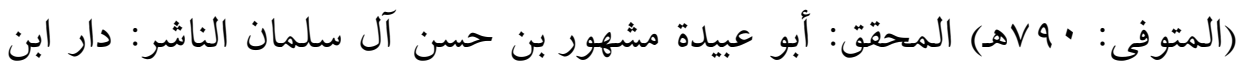

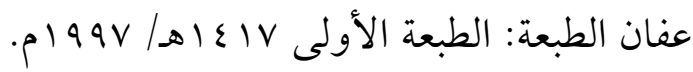
10 -نحو تفعيل مقاصد الشريعة د: جمال الدين عطية ظبعة دار الفكر والمعهد العالمي للفكر الإسلامي لسنة r... بم.

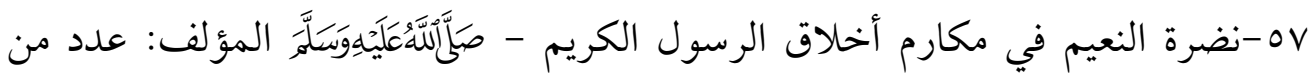

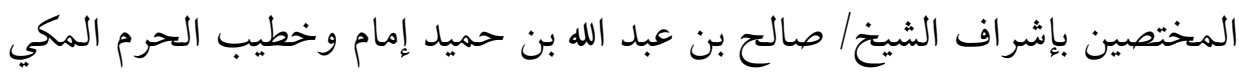

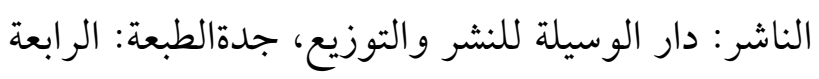

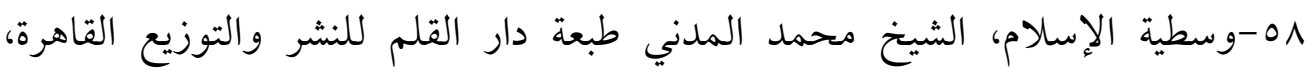

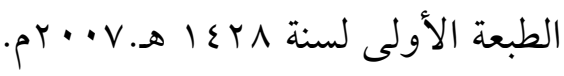
هo- وسطية الإسلام وسماحته - محمد الصالح، بترقيم الشاملة آليا) الناشر: الكتاب منشور على موقع وزارة الأوقاف السعودية بدون بيانات.

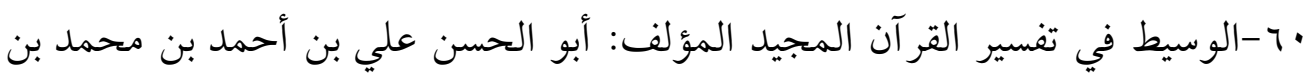

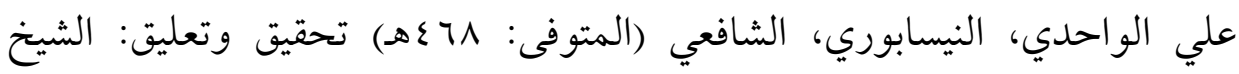

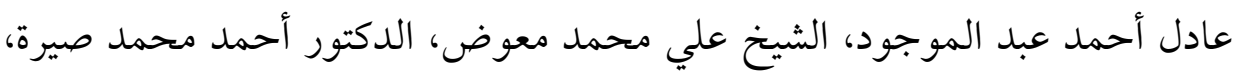

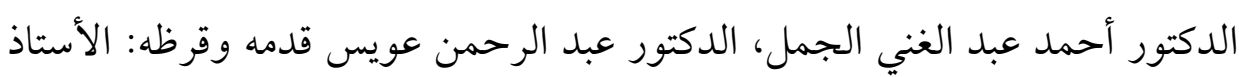
الدكتور عبد الحي الفرماوي الناشر: دار الكتب العلمية، بيروت - لبنان الطبعة:

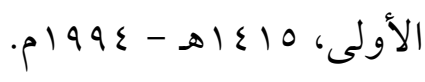




\section{General sources and references}

First: The Noble Qur'an 0000 Glory be to the one who revealed it.

Second: The most important sources and references in alphabetical order:

1- Islam Almoftra alya byn alshuein wa al rasmalyeen : Sheikh Muhammad Al-Ghazali, edition of Egypt's Renaissance House, first edition.

2- Islam aqedah wa shariah: The Grand Imam, Sheikh Mahmoud Shaltout, published by Dar Al-Shorouk, the eighteenth edition in 2001 AD.

3- Islam wa bena alshakhseya: Dr. Ahmed Omar Hashem, edition of Dar Al-Manar for Publishing and Distribution, Cairo.- 3

4- Al-Shabab Al-Nazaer Author: Abd al-Rahman Ibn Abi Bakr, Jalal alDin al-Suyuti (died: $911 \mathrm{AH}$ ) Publisher: Dar al-Kutub al-Ilmiyya Edition: First, 1411 AH - $1990 \mathrm{CE}$

5- Usul al-Figh Author: Imam Muhammad Abu Zahra, Dar al-Fikr alArabi, S. 2006 AD - 1427 AH

6-Usul Almojtama Alislami , author: Dr. Jamal Al-Din Muhammad Mahmoud, edition of the Egyptian Book House, Cairo, Lebanese Book House, Beirut, first edition, 1412 AH 1992 AD.

7- Itelal alqolob by Al-Karatibi, the author: Abu Bakr Muhammad Banja', Afar Ibn Muhammad Ibn Shal Banshakir, the cartographer, the Samaritan (died: $327 \mathrm{AH}$ ), investigation: Hamdi Al-Demirdash, Publisher: Nizar Mustafa Al-Baz, Makkah Al-Mukarramah - Riyadh Edition: Second, 1421 AH 2000 AD

8- Ummah Al- Wasat and the Path to the Prophet in the Call to God Author: Abdullah bin Abdul Mohsen, Turkey Edition: First: The Ministry of Islamic Affairs, Endowments, Call and Guidance Kingdom of Saudi Arabia: $1418 \mathrm{AH}$

9- Tarikh al-Tabari, the author: Muhammad ibn Jarir ibn Yazid ibn Katheer ibn Ghalib al-Amali, Abu Jaafar al-Tabari (died: $310 \mathrm{AH}$ ) (relationship to the history of al-Tabari by Oraib ibn Saad alQurtubi, deceased: 369 AH) Publisher: Dar al-Turath - Beirut Edition: second - $1387 \mathrm{~h}$ 
10- Intolerance and tolerance between Christianity and Islam Sheikh Muhammad Al-Ghazalat Nahdet Misr for the year 2005AD-

11- Tafsir Al-Shaarawy - Al-Khawatir Author: Muhammad Metwally AlShaarawi (died: 1418 AH) Publisher: Press, News Today, Published in 1997 AD

12- Tafsir al-Tabari = Jami' al-Bayan T Shakir Author: Muhammad Banjarir Benazid Bankhir Banghalib al-Amli, Abu Jaafar al-Tabari (died: $310 \mathrm{AH}$ ) Investigator: Ahmad Muhammad Shakir Publisher: Foundation al-Risala Edition: First, $1420 \mathrm{AH}-2000$

13- Tafsir Qur'an Al-Azeem Author: Abu Al-Fida Ismail bin Omar Bank Kather Al-Qurashi Al-Basri Thamal Al-Dimashqi (deceased: $774 \mathrm{AH}$ ) Investigator: Sami bin Muhammad Salama Publisher: Dar Tiba for Publishing and Distribution Edition: Second 1420 AH - 1999 AD

14- Tafsir Qur'an Al-Azeem by Ibn Abi Hatim Author: Abu Muhammad al-Rahman ibn Muhammad ibn Idris ibn al-Mundhir al-Tamimi, alHanazali, al-Razi ibn Abhitam (died: 327 AH) Investigator: Asaad Muhammad al-Tayyib Publisher: Nizar Mustafa al-Baz Library Kingdom of Saudi Arabia Edition: Third - 1419 AH

15- Tafsir Al-Waset Author: Dr. Wahba bin Mustafa Al-Zuhaili Publisher: Dar Al-Fikr - Damascus For the first edition - $1422 \mathrm{AH}$

16- Tafsir Al-Waset of the Noble Qur'an Author: Muhammad Sayed Tantawi Publisher: Dar Nahda Misr for Printing, Publishing and Distribution, Faggala - Cairo Edition: First.

17- Tafsir of Yahya bin Salam, the author: Yahya bin Salam bin Abith Alaba, Al-Timbi Al-Walaa, Mintim Rabi'a, Al-Basri, Thamal AlAfrican Al-Qayrawani (deceased: $200 \mathrm{AH}$ ). Presented and investigated by: Dr. Hend Shalaby, Publisher: Dar Al-Kutub AlIlmia, Beirut - Lebanon Edition: First, 1425 A.H. - 2004 A.D.

18- The organization of Islam for society Sheikh / Muhammad Abu Zahra pg. 191 Briefly and disposed of I Al-Awwal, Dar Al-Fikr AlArabi for the year 1999 AD

19- Islamic civilization, its foundations and means, images of Muslims' applications to it, and glimpses of its impact on other nations. Publisher: Dar Al-Qalam - Damascus Edition: The first updated elements of the book plan $1418 \mathrm{AH}-1998 \mathrm{AD}$ 
20- Arab Civilization: Dr. Gustave Le Bon, Transfer to Arabic, Professor: Adel Zaatar, Edition of the House of Reviving Arab Heritage, Beirut, third edition in $1399 \mathrm{AH}$.

21- Human Rights between the Teachings of Islam and the Declaration of the United Nations: Sheikh Muhammad Al-Ghazali. I Nahdet Misr b-d.

22- The role of the Muslim, the messenger of the divine message, in the last third of the twentieth century, the author: Malik Ibn AlHajj Omar Ibn Al-Khadr Ibn Nabi (deceased: 1393 AH / Al-Fikr: AlFikr 14th edition, 1991 AD)

23- The Pioneer Lessons in Education and Advocacy: Sheikh: Mazen Bin Abdul Karim Al-Fraih, Dar Al-Andalus Al-Khadra, Jeddah. First Edition 1423 AH: 2002 AD

24- Social Behavior in Islam, Hassan Ayoub, Dar al-Salaam edition, 1st edition, 2002AD-24

25- Sunan Al-Tirmidhi Author: Muhammad Bin Issa Bin Soura Bin Musa Bin Al Dahak, Al Tirmidhi, Abu Eissa (deceased: $279 \mathrm{AH}$ ) investigation and commentary: Ahmed Muhammad Shaker (vol. 1, 2) and Muhammad Fouad Abdel-Baqi (vol. 3) and Ibrahim Maatwa Awad the teacher in Al-Azhar Al-Sharif $(C .4,5)$ Publisher: Al-Babi Company: Al-Halabi Library - Mustafa 13th Edition

26- Al-Sira Al-Nabawyah Presentation of facts and analysis of events: by Dr. Ali Muhammad Al-Sallabi Edition of Iqra Foundation, first edition in 2005 AD

27- Al-Sira Al-Nabawyah Bensham, the author: Abd al-Malik Ibn Hashim, Ibn Ayub al-Hamiri al-Ma'afari, Abu Muhammad, Jamal alDin (died: $213 \mathrm{AH}$ ) investigation: Mustafa al-Saqqaw, Ibrahim alAbyari, Abdul Hafeez al-Shalabi, Publisher: Mustafa al-Babi alHalabi Library and Printing Company, and Awlad Deb, Egypt Edition: Second, 1375 AH - 1955 AD

28- Shams Al- Arab Tasta ala algharb: Dr. Sigrid Hunke, Dar Sader, Beirut, translated by Farouk Baydoun and Kamal Desouki, tenth edition, year $1423 \mathrm{AH}$.

29- Sahih al-Bukhari: Imam Muhammad ibn Ismail ibn Ibrahim ibn alMughirah al-Bukhari, Abu Abdullah Investigator: Muhammad 
Zuhair ibn Nasir al-Nasir, Publisher: Dar Touq al-Najat, Edition: First year $1422 \mathrm{AH}$.

30- Sahih al-Jami al-Sagheer and its additions, the author: Abu alRahman Muhammad Nasir al-Din, Ibn al-Hajj and Habbinnajati Ibn Adam, al-Ashqud riyal al-Albani (died: $1420 \mathrm{AH}$ ) Publisher: alMaqtab al-Islami.

31- Sahih Muslim: Imam Muslim ibn al-Hajjaj Abu al-Husayn alQushayri al-Nisaburi Investigation: Muhammad Fouad Abd al-Baqi Publisher: Arab Heritage Revival House, Beirut.

32- Suwar min Hayat Al-Tabeen: Abd al-Rahman al-Basha, edition of Dar al-Adab al-Islami, Cairo, the fifteenth edition, s $1418 \mathrm{AH}$.

33- Tabe Al- Islam bayn aladyan: Professor Anwar El-Gendy. Dar AlAnsar edition, first edition, year 1399 AH - 1979 AD.

34- Elm Almaqased alshareyh Author: Noureddine Bin Mukhtar AlKhadidi Publisher: Obeikan Library Edition: First 1421 AH - 2001 AD.

35- Gharaib Al-Tafsir and the wonders of interpretation, the author: Mahmoud Bin Hamza Bin Nasr, Abu Al-Qasim Burhan Al-Din AlKarmani, known as Taj Al-Qura' (died: about 505 AH) Publishing House: Dar Al-Qibla for Islamic Culture - Jeddah, Foundation for Quran Sciences - Beirut

36- Al-fawed fi Ikhtesar almaqased Author: Abu Muhammad Izz al-Din Abd al-Aziz ibn Abd al-Salam ibn Abi al-Qasim ibn al-Hasan alSalami al-Dimashqi, nicknamed the Sultan of Scholars (deceased: 660 AH) Investigator: Iyad al-Tabbaa Publisher: Dar al-Fikr Contemporary, Dar al-Fikr - Damascus Edition: First, 1416

37- Al-Qamos Alphabetical , Yahya bin Al-Hajj Al-Jilani and others, AlAhlia Publishing Edition, Beirut: for the year 1997 AD

38- Al-Qamos Fiqh , Author: Dr. Saadi Abu Habib, Publisher: Dar AlFikr. Damascus - Syria Second Edition: 1408 AH = 1988 AD.

39- Qawed alahkam fi masalh alanam, Izz al-Din Abdel Aziz bin Abd alSalam, Publisher: Library of Al-Azhar Colleges, Cairo Edition: New, revised, and corrected, $1414 \mathrm{AH}$ - $1991 \mathrm{AD}$. Reviewed and commented on by: Taha Abdel-Raouf Saad.

40- Alqawed alfiqhyah and their applications in the four schools of 
thought Author: Dr. Muhammad Mustafa Al-Zuhaili. Publisher: Dar Al-Fikr, Damascus Edition: First, 1427 AH - 2006 AD.

41- Alkoliyat, Dictionary of Terminology and Linguistic Differences Author: Ayoub Benmoussa Al-Husseini Al-Quraymi Al-Kafawi, Abu Al-Baqa Al-Hanafi (died: 1094 AH) Investigator: Adnanandweesh Muhammad Al-Masry Publisher: Al-Resalah Foundation - Beirut

42- Majmoat alfawed albahyah on the system of jurisprudence rules by the author: Abu Muhammad, Salih Bin Muhammad Bin Hassan Al-Omair, Al-Asmari, Al-Qahtani Take care of its production:

Mutaib Bin Masoud Al-Jaid Publisher: Dar Al-Sumaei for Publishing and Distribution, Kingdom of Saudi Arabia - 1420 ed. Edition: First

43- Almoharr alwajez in the interpretation of the dear book, the author: Abu Muhammad Abdul Haq bin Ghalib bin Abdul Rahman bin Tamam bin Attia Al-Andalusi Al-Muharibi (died: $542 \mathrm{AH}$ ) Investigator: Abdul Salam Abdul Shafi Muhammad Publisher: Dar Al-Kutub Al-Alamia - Beirut Edition: First - $1422 \mathrm{AH}$

44- Almahsol Author: Abu Abdullah Muhammad bin Omar bin Al Hassan bin Al Hussein Al Taimi Al Razi, nicknamed Fakhr Al Din Al Razi Khatib Al Ray (died: $606 \mathrm{AH}$ ) Study and investigation: Dr. Taha Jaber Fayadh Al Alwani Publisher: Foundation Al Risalah Edition: Third, 1418 AH - 1997 AD.

45- Al-mohakam wa almohyt alazam Author: Abul-Hasan Ali Bin Ismail Binsidhal Al-Mursi [T: 458 AH] Investigator: Abd al-Hamid Dawi Publisher: Dar al-Kutub al-Ilmiyya - Beirut Edition: First, $1421 \mathrm{AH}$ 2000 AD

46- Mukhtar Al-Sahah Author: Zainal-Din Abu Abdullah Muhammad Ibn Abi Bakr Ibn Abd al-Qadir al-Hanafi al-Razi (deceased: $666 \mathrm{AH}$ ) Investigator: Youssef Sheikh Muhammad Publisher: The Modern Library - Al-Dar Al-Nazim, Beirut - Saida Edition: Fifth Edition, 1420 AH / 1999 AD.

47- Al-Mustafa fi Ilm al-Usul, Imam Muhammad bin Muhammad alGhazali, edited by Muhammad Abd al-Salam Abd al-Shafi, Dar alKutub al-Ilmiyya, Beirut, i. $1413 \mathrm{AH}$.

48- Maelm altanzyl fi tafsir al Qur'an = Tafsir al-Baghawi, the author: Muhyi al-Sunnah, Abu Muhammad al-Husayn ibn Masoud ibn 
Muhammad ibn al-Farra al-Baghawi al-Shafi'i (died: $510 \mathrm{AH}$ ) Investigator: Abd al-Razzaq al-Mahdi, Publisher: Arab Heritage Revival House - Beirut Edition: First, $1420 \mathrm{AH}$

49- Al-Majjam alwaset: Author: The Arabic Language Academy in Cairo (Ibrahim Mustafa / Ahmed Al-Zayyat / Hamed Abdel-Qader / Muhammad Al-Najjar) Publisher: Dar Al-Da'wah

50- almofradat fi gharib Qur'an Author: Abu al-Qasim al-Husayn ibn Muhammad al-Maarouf al-Ragheb al-Asfahani (died: $502 \mathrm{AH}$ ) Investigator: Safwan Adnan al-Dawdi Publisher: Dar al-Qalam, alDar al-Shamiya - Damascus, Beirut Edition: First - $1412 \mathrm{AH}$

51- Maqasid al-Shari'ah, Sheikh Muhammad al-Taher Ibn Achour, i Tunisian Distribution Company, 1978 AD-51

52- Al-Milal wa-I-Nahl by Al-Shahristani Muhammad Abdul-Karim, investigated by Abdul-Aziz Muhammad Al-Wakeel, Al-Halabi and Partners Foundation, 1387 AH/1968 AD.

53- Manaqib ameer almoeminen, Omar Ibn Al-Khattab, may God be pleased with him, by Al-Hafiz Ibn Al-Jawzi, Dar Al-Kutub Al-Ilmia, Beirut, without the edition and the year of publication, investigated by Dr. Zainab Ibrahim Al-Qarout and Kenz Al-Amal fi Sunan al-Sayyal wa al-Amal by Aladdin Ali Al-Hindi, T. 975. Message Foundation.

54- Al-mowafaqat Author: Ibrahim bin Musa bin Muhammad AlLakhmi Al-Gharnati, famous for Al-Shatby (died: $790 \mathrm{AH}$ ) Investigator: Abu Obaida Mashhour bin Hassan Al-Salman Publisher: Dar Ibn Affan Edition: First Edition 1417 AH / 1997 AD. 56- Nahwa tafeel Maqased Al-Sharia.

57- Nadhra Al-Naim in the morals of the Noble Messenger - may God bless him and grant him peace.

58- Wasatyt Al- Islam, Sheikh Muhammad Al-Madani, Dar Al-Qalam Edition for Publishing and Distribution, Cairo, first edition for the year 1428 AH. 2007 AD.

59- Wasatyt Al- Islam wa samahath- Muhammad Al-Saleh, with automatic comprehensive numbering) Publisher: The book is published on the website of the Saudi Ministry of Endowments without data. 
60- Al-Wasifi, Interpretation of the Glorious Qur'an, Author: AbulHassan Ali Bin Ahmed Bin Muhammad Bin Ali Al-Wahidi, AlNaysaburi, Al-Shafi'i (deceased: $468 \mathrm{AH}$ ), investigation and commentary: Sheikh Adel Ahmed Abdel-Mawgoed, Sheikh Ali Muhammad Moawad, Dr. Ahmed Muhammad Sira, Dr. Ahmad Abd al-Ghani al-Jamal, Dr. Rahman Awais Qadhouqrah: Professor Dr. Abd al-Hayy al-Farmawi, Publisher: Dar al-Kutub al-Ilmiyya, Beirut - Lebanon Edition: First, 1415 AH - 1994 AD.

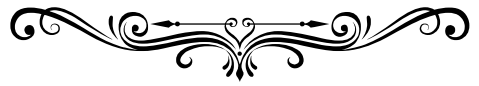




\section{فهربس الموضوعات}

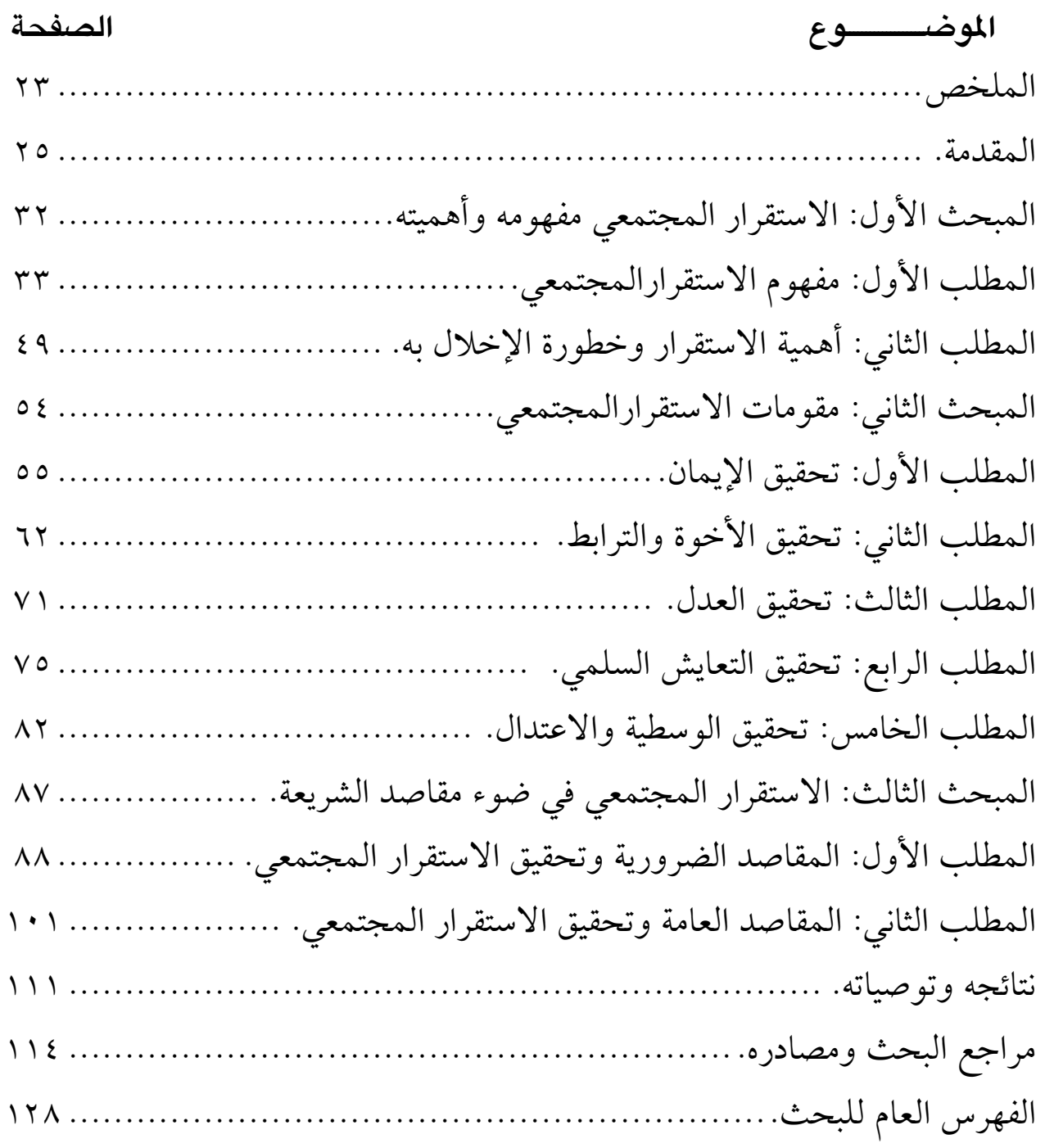

aria 